University of Pennsylvania Carey Law School

Penn Law: Legal Scholarship Repository

Faculty Scholarship at Penn Law

$5-11-2005$

\title{
Signaling Social Responsibility: On the Law and Economics of Market Incentives for Corporate Environmental Performance
}

Jason S. Johnston

University of Pennsylvania Carey Law School

Follow this and additional works at: https://scholarship.law.upenn.edu/faculty_scholarship

Part of the Environmental Law Commons

\section{Repository Citation}

Johnston, Jason S., "Signaling Social Responsibility: On the Law and Economics of Market Incentives for Corporate Environmental Performance" (2005). Faculty Scholarship at Penn Law. 63.

https://scholarship.law.upenn.edu/faculty_scholarship/63

This Article is brought to you for free and open access by Penn Law: Legal Scholarship Repository. It has been accepted for inclusion in Faculty Scholarship at Penn Law by an authorized administrator of Penn Law: Legal Scholarship Repository. For more information, please contact PennlawIR@law.upenn.edu. 


\title{
Signaling Social Responsibility: On the Law and Economics of Market Incentives for Corporate Environmental Performance
}

\author{
By Jason Scott Johnston ${ }^{1}$ \\ Robert G. Fuller, Jr. Professor and Director, \\ Program on Law and the Environment \\ University of Pennsylvania Law School \\ This version, (C) May 11, 2005
}

\section{Introduction}

One of the oldest bits of legal folk wisdom is that environmental, health and safety laws are only as strong as their enforcement by public regulators and private citizen suit litigants. In this article, I argue that this piece of folk wisdom is false. The everyday world of market transactions - purchases and sales of stock and other corporate assets by investors, as well as consumer transactions - significantly enhances the incentives created by regulatory and legal enforcement. Regulatory compliance costs and potential regulatory sanctions for noncompliance are felt in virtually every transaction involving the purchase, sale or restructuring of a company or its assets. Whether deals occur at all, and the price negotiated in such deals, is very often a direct function of the underlying regulatory regime within which firms operate. For an increasing number of investors and consumers, moreover, the decision whether to transact at all - whether to buy a company's product, or invest in its stock - is

\footnotetext{
${ }^{1}$ An early summary of the analysis in this paper was presented at the May, 2003 Program on Law and the Environment Roundtable entitled "Capital and Conservation." I am grateful to all the Roundtable participants for an insightful and illuminating discussion, and especially to Cary Coglianese and Mike Radcliffe for comments following the presentation and to Jeff Smith for written comments. Later versions of this article were presented to the Ad Hoc Workshop at Penn Law, the Law and Economics workshops at the University of Michigan and Vanderbilt University Law Schools, and the Spring, 2004 Annual Meeting of the American Law and Economics Association. Thanks are due to Larry Hammermesh, Kristin Madison and Eric Orts for helpful written comments. Responsibility for errors and sloppy thinking remains, of course, mine.
} 
made by looking not just at what a company sells - its product, or the risk-return package presented by a share of its stock - but by looking at how the company does business - at its environmental, health, safety and labor practices. When consumer and investors' willingness to pay depends not just on "what" but on "how", product and stock markets may themselves directly reward companies for internalizing regulatory norms.

Market internalization -- the capability of markets to both penalize and reward firms for their environmental, health and safety performance -- provides a fundamentally new view from which to understand and evaluate environmental, health and safety laws and regulations. When market sanctions - such as lower stock prices - are the primary sanction for environmental and regulatory compliance failures, actual or realized regulatory effectiveness is no longer contingent upon the scope and extent of public and citizen enforcement, but upon the quality of the information about regulatory costs and liabilities that gets to market participants and how quickly it gets there. The traditional legal focus on administrative process issues pertaining to and the timing and scope of judicial review is replaced, on the market internalization model, with a focus on laws and regulations that determine the quantity and type of information that is available to private markets. These include what might be called market information legal rules, those that regulate firms' voluntary and mandatory disclosures and that assign potential liability for false disclosures. Market internalization is also strongly affected by regulatory substance -- on the clarity and simplicity of firms' regulatory requirements, and on the extent to which regulatory costs are indeed reasonably estimable.

Even more dramatically and generally, only when one recognizes the tremendous sensitivity of firms to their market reputation - both positive and negative - and the huge effort that firms make in communicating information to build such reputation, can one see 
that the regulation of corporate speech is a crucial determinant of corporate incentives for environmental, health and safety policies and performance. Market internalization depends on information, but if all companies have the same general incentive to conceal bad news and exaggerate good news (even to the point of making false claims about their performance), then private incentives in communicating to markets will not generate the required information. It may seem that the market itself - in the form of private, third party certification of reports about corporate regulatory performance - will trigger the supply of such credible information that markets demand. But this is to beg the question of just how it is that private, third party certification will itself be credible. As with financial markets, once we turn our attention to market incentives, there is an inevitable and fundamental question regarding the role of legal liability for false or misleading market communications not only by companies, but by the third parties who audit and certify company regulatory performance reports. Inasmuch as it is not only traditional accounting firms but also wellestablished environmental non-governmental organizations who are acting as such private, third party auditor/certifiers, the market internalization model I develop here generates a novel and quite unexpected possibility, that the potential legal liability of environmental ngo's may be necessary to fully realize market incentives for corporate environmental performance.

There is a vast and growing literature in economics, accounting and business that explores how markets can offer firms both carrots for superior environmental performance and sticks for poor performance. Some of this literature is quite sanguine, indeed gushing about the potential harmony between the firm's legal and regulatory requirements and its 
economic goals. $^{2}$ It thus flips the neoclassical economic critique of corporate social responsibility (CSR) as corporate philanthropy that harms the overriding objective of shareholder wealth maximization, finding that costly CSR can be good for society and shareholders. $^{3}$

There are signs that as CSR is subjected to more sustained and increasingly rigorous analysis, this Panglossian view of harmony between the firm's interest in maximizing profits and society's interest in minimizing external harm from the firm's operations will be replaced by a more nuanced and skeptical view. ${ }^{4}$ Even if more realistic in its attitude, the economic and business literature on CSR has generally ignored or spoken only in very general terms about the role of laws and regulations in facilitating market internalization. It has also tended to neglect the world of private transactions in corporate assets, a world that is primary for many corporate lawyers.

The legal literature has, unsurprisingly perhaps, had the opposite problem, tending to ignore CSR and socially responsible markets as phenomena of general significance for the design of regulatory rules and institutions. There has traditionally been concern with whether corporate fiduciary duties of top management allow them to have the corporations

\footnotetext{
2 Some have gone so far as to argue that costly environmental regulation actually motivates firms to reduce their costs and improve profitability. See, for example, Michael Porter and C.van der Linde, Green and Competitive: Ending the Stalemate, 73 Harv. Bus. Rev. 120 (1995); Forest L. Reinhardt, Down to Earth: Applying Business Principles to Environmental Management (2000); but see Andrew A. King and Michael J. Lenox, Does it Really Pay to be Green? An Empirical Study of Firm Environmental and Financial Performance, 5 J. Indus. Ecol. 105 (2001).

${ }^{3}$ A more recent formulation of the neoclassical position is Jensen's notion of “enlightened value maximization," under which the firm takes account of various, conflicting stakeholder interests, and resolves conflicts among them so as to maximize the long run value of the firm. But on Jensen's view, the solution for externalities is in assigning property rights. Michael C. Jensen, Value Maximization, Stakeholder Theory, and the Corporate Objective Function, 9, 12, Amos Tuck School of Business, Dartmouth College, Working Paper No. 01-09 (2001).

${ }^{4}$ In the popular press, see Clive Crook, The Good Company, The Economist, January 22, 2005, 3-22; for academic skepticism see King and Lennox, supra note _, and Paul R. Portney, Corporate Social Responsibility: An Economic and Public Policy Perspective, in Environmental Protection and the Social Responsibility of Firms: Perspectives from Law, Economics and Business 107 (Bruce L. Hay, Robert N. Stavins and Richard H.K. Vietor, eds. 2005).
} 
they control make charitable gifts and engage in various other philanthropic activities, ${ }^{5}$ as well with the Securities and Exchange Commission's rules regarding the (limited) obligations of publicly traded companies to disclose general non-financial information and more specific obligations to disclose potential regulatory costs and liabilities. ${ }^{6}$ Only very recently have legal commentators recognized the market's potential to both reward good corporate behavior ${ }^{7}$ and reflect bad corporate behavior. ${ }^{8}$ While useful in identifying particular kinds of market responses, ${ }^{9}$ this recent legal scholarship has failed to see the generality of the market internalization phenomenon, oddly failing, for instance, to discuss the role of public securities markets that has been central to economic and business writing about CSR. Even more importantly, the nascent legal literature fails to rigorously analyze how and when market internalization impacts corporate behavioral incentives. Without such rigorous analysis, it is impossible to systematically evaluate proposals for legal or regulatory reform, and one is left with either vague general prescriptions ${ }^{10}$ or cautious and often conflicting ad hoc suggestions. ${ }^{11}$

In this article, I attempt to remedy this gap in the literature by providing an economic analysis of how legal rules shape market incentives for CSR. This analysis reveals not just the centrality of information to the existence and strength of market incentives, but

\footnotetext{
${ }^{5}$ For an exhaustive and authoritative discussion of this literature and an argument that fiduciary duties of management do not preclude CSR, see Einer Elhauge, Corporate Managers Operational Discretion to Sacrifice Profits in the Public Interest, in Environmental Protection and the Social Responsibility of Firms, supra note _ at 13

${ }^{6}$ See Cynthia A. Williams, The Securities and Exchange Commission and Corporate Social Transparency, 112 Harv. L. Rev. 1197 (1999), and see discussion infra at notes _ to _ .

${ }^{7}$ Douglas A. Kysar, Preferences for Processes: The Process/Product Distinction and the Regulation of Consumer Choice, 118 Harv. L. Rev. 525 (2004).

${ }^{8}$ Michael P. Vandenbergh, The Private Life of Public Law: Accounting for the Influence of Private Agreements on Public Regulation, forthcoming _ Colum. L. Rev. _ (2005).

${ }^{9}$ In the case of Kysar, consumer product markets, and in the case of Vandenbergh, markets for corporations and their assets.

${ }^{10}$ See Kysar, supra note _ at 579-640 (discussing implications of consumer process preferences for international trade and product disclosure laws).

${ }^{11}$ Vandenbergh, supra note _ at 53-61.
} 
provides insight into how and when mandatory disclosure and/or legal liability for false communications is necessary to supplement the incentives for voluntary disclosure that the existence of socially responsible markets provides alone.

"Social responsibility" is, of course, hardly a self-defining term. Here, I simplify analysis by equating a firm's performance on some general social responsibility scale with its environmental performance as measured against both existing regulatory and legal standards and a general sense of what constitutes "best practice" within an industry or sector. My analysis reveals that market transactions - both private and public sales of corporate assets as well as transactions in publicly traded securities - are an important avenue through which firms realize comparative advantages in regulatory compliance, and that such transactions have the potential to significantly enhance corporate environmental and social performance. Asset transactions tend to drive environmental cleanup and transfer assets to firms that are better able to know about and comply with relevant regulatory directives. Due diligence in such transactions generates new information about environmental problems, and environmental fixes. On public securities markets, the very fact that traders are imperfectly informed about firm-specific regulatory risk causes disproportionately large market reaction to the revelation of such risks. The incentive to avoid such large, negative market reactions to the revelation of negative information leads may induce a higher level of compliance than were no such market reaction anticipated.

This does not, however, lead to the further implication that corporate managers will have an incentive to voluntarily disclose negative environmental (regulatory) news. Incentives for voluntary disclosure of negative information are complex, but in general, the problem that firms have is in credibly committing to make such disclosure. Mandatory 
disclosure requirements may be crucial in allowing firms to make such credible commitments.

As for the potential positive rewards (in the form of price premia) that SR consumers and investor offer to firms that they perceive to be pursuing CSR, the fundamental problem identified by my analysis is once again informational: CSR cannot be directly observed by consumers and investors, and so unless firms can find a credible signal of CSR, the positive potential of the market may go unrealized. Third party certification of firm-specific CSR, as by environmental groups, has the potential to restore credibility, but only if the market for such third party certifiers is sufficiently robust and competitive. Inevitably, much corporate communication regarding CSR is what economists call cheap talk. My analysis of CSR communication as cheap talk generates two basic predictions. The first is that firms of a particular size and in a particular industry are unlikely to be concerned with issues of CSR until regulators, or perhaps ngo's have targeted them and publicized their activities as having a high environmental impact. Second, once such impacts have become well known, one would expect to see that all firms in a particular, targeted size/industry category issue CSR reports. From these two predictions, there is a final implication: from the fact that firms in a particular size/industry category uniformly issue CSR reports, one can conclude that the category is widely perceived to have a high environmental and social impact; such reports do not, however, generate information on the relative economic and social performance of firms within such a category.

By thinking about the market first, and the law second, this article's analysis permits a revisioning of the law's role in shaping corporate incentives for environmental and social performance. My analysis suggests that from the point of view of enhancing, rather than supplanting, market incentives, the most important thing that laws and regulations do may 
be to help firms commit to credible communication about their environmental performance. That is, on this view, the legal rules that are most crucial in improving CSR are not regulations that try to mandate SR corporate behavior, but rather those determining when and if companies are liable for either failing to disclose or falsely communicating about their social and environmental performance. I explore two areas of the law - securities rules governing the obligation of companies to disclose non-financial, social and environmental performance information, and the issue of when false SR claims should be actionable as a form of false advertising - that illustrate many of the issues raised in thinking about the role of legal liability in bonding credible corporate communication. I then conclude by developing some of the normative implications of the analysis for the design of laws and regulations pertaining to such issues as mandatory disclosure of corporate environmental performance and the extent of liability for environmental non-compliance.

As for laws and regulations governing the disclosure of "bad" corporate environmental news, my analysis supports the SEC standard requiring the disclosure only of those environmental regulatory costs and liabilities that are "probable" and "reasonably estimable." This standard makes good sense as tracking the de facto limits of current accounting practice. The SEC's almost complete failure to enforce its rules regarding the disclosure of environmental risks, however, has made it impossible for corporate managers to credibly commit to being one of the "good guys" by voluntarily disclosing such bad news. With no threat of SEC enforcement, managers of public companies have an incentive not to reveal bad environmental news, but to conceal it. There are commonly observed and yet egregious examples of concealing strategies that the SEC should enforce against. Such enforcement would go a long way toward making it possible for companies to credibly commit to effective voluntary disclosure. 
As for good news, the policy question that I focus on is the potential for legal liability for false assertions of CSR to deter "bad" companies from pretending to be "good" ones via their CSR communications, thus generating an uninformative (or babbling) market equilibrium. I discuss two separate questions: the economic case for potential liability for communications regarding corporate social responsibility as false advertising; and the potential liability of third party certifiers of CSR. I argue that what is valuable about potential civil liability is not the prospect that firms that lie about their labor practices or environmental performance may be held liable for damages or made to pay fines. Indeed, the magnitude of liability for false assertions of this sort ought to be strictly limited. What is valuable about potential liability is the access to civil discovery that it affords plaintiffs, access that allows for the discovery of information regarding corporate labor and environmental practices that otherwise would be asymmetrically available only to the corporate speaker.

Civil discovery is not the only way that such information can be produced. I conclude the article by analyzing the alternative of private, third party certification of CSR disclosures and assertions. Whether done by large accounting firms, or environmental or other ngo's, such certification is a market response to SR consumers' and investors' demand for credible, reliable firm-specific information. For such private certification to be informative, however, it must itself be credible. While market reputation clearly helps ensure the truthfulness and credibility of private auditors' CSR reports, the risk of collusion between audited companies and their auditors is just as great when it comes to CSR as it is in the traditional area of financial report auditing. Just as with financial reports, the threat of legal liability for intentionally or negligently false CSR audit reports may be necessary for private CSR auditing to generate credible information. 
Thus in the end, just as the tremendous success of American securities markets has been built upon a regulatory regime that ensures that truthful and credible financial information is communicated to the market, so too may the potential for the new world of socially responsible markets to induce companies to internalize social and environmental harms depend upon a sensible legal regime of mandatory, standardized disclosure and (limited) liability for false speech.

\section{The Market Multiplier: Rational Private Actors and the Effect of Market Transactions in Enhancing Incentives for Corporate \\ Environmental Performance}

Markets can provide both carrots and sticks. They can effectively increase the sanction that companies face for having poor environmental records, thus magnifying the deterrent effect of environmental laws and regulations. Because this effect is primarily translated through the price and availability of market transactions, I call it the transactional multiplier. Even if there were no environmental laws and regulations, and hence no potential environmental liabilities, ${ }^{12}$ investors and consumers with a direct interest in a firm's environmental performance might effectively reward strong performers by paying a stock market or product price premium. Just like the transactional multiplier, these positive effects - from what I call socially responsible markets -- depend crucially upon the information that market participants have about corporate environmental performance.

\footnotetext{
12 Throughout the analysis which follows, I refer to environmental liabilities. I mean these in a broad sense, to include not only potential civil penalties for violations of environmental laws and regulations, but also tort damage awards.
} 
In this part, I analyze the potential for market transactions to multiply the effect of a firm's regulatory and common law environmental liabilities and risks, to add a market penalty to the "kick" of regulatory and common law enforcement. This analysis generates concrete normative recommendations for regulatory and legal policies that determine the potential scope, and relative uncertainty, of such environmental liabilities.

\section{A. Rational Private Investors}

Firms engage in a wide variety of transactions. Firms buy or sell assets, such as land (but including entire firms). They obtain capital by selling equity or borrowing. They purchase raw materials and intermediate goods, as well as labor services, and sell their goods and services either to other firms or to consumers. For what I shall call a rational private investor, what matters in choosing whether and on what terms to transact with a firm are the private benefits and costs that they get from such transactions. Rational investors in this sense are interested in the financial return from their investment. They care about the firm's regulatory exposure not because they directly care about third party harms such as pollution or poor working conditions that may trigger regulatory liability and/or compliance expenditures, but only insofar as regulatory costs impact the firm's bottom line financial return.

In this part I analyze how transactions between a rational, profit maximizing firm and such rational investors can magnify the incentive for firm regulatory compliance beyond that which is created by the regulatory enforcement structure alone. I begin, moreover, with the simple case in which the investor is an individual or firm that is acquiring sole ownership and control over an asset. The asset may be one of many held by the selling firm, such as a 
parcel of land, or the entire company. Thus I begin with might best be called the rational private transactional market, a world inhabited by firms, private equity funds and the like.

Later in the article, I analyze the behavior of investors who have broader objectives, and who directly care about third party harms caused by firms (or assets more generally) which they own (all or in part). I call such investors socially responsible, or SR investors. I also analyze the behavior of SR consumers, who are likewise have preferences not just over standard consumption attributes of a good or service, but who also get utility or disutility from the external harms or benefits generated by the firm's operations. There are, of course, lots of consumers whose preferences are narrower in that they care only about what the consumption of a good or service does for them, and care nothing about how the good or service is being produced, or about any other aspect of the selling firm's operations. I do not separately analyze how these ordinary sales transactions might magnify the firm's incentive for environmental performance. Because external harms don't enter the utility functions of neoclassical consumers), how much they pay for a product or service has nothing to do with the level of such harm generated by a firm. Neoclassical consumers do figure in my analysis below, but only in the context of analyzing firm incentives for SR behavior in consumer markets where there is a mix between SR and neoclassical consumers.

B. The Benchmark of Transactional Neutrality for Rational Private Investors For rational private investor, the idea that market transactions can somehow enhance the incentive for CSR created by laws and regulations reduces to the relatively precise question of how the market price paid by such ordinary consumers and investors is affected by the firm's regulatory liabilities. To clarify this question, consider an ordinary investor considering the acquisition of two alternative assets, one environmentally clean, the other environmentally dirty. The environmentally dirty asset carries potential future environmental 
liabilities (either common law or regulatory), while the clean asset does not. ${ }^{13}$ The potential environmental liabilities of the dirty asset represent a claim against the future cash flow generated by that asset. Note that by potential liabilities I mean future regulatory compliance costs, not existing judgments or liabilities. When and if an asset buyer should be liable for existing liabilities is an important normative issue that I discuss below; I assume that future regulatory compliance costs will necessarily be costs assumed by the buyer. The future, contingent environmental liabilities lower the value of the asset to a potential buyer. Relative to an environmentally clean asset, the environmentally dirty asset fetches a lower market price.

The incentive to manage assets to their highest market value creates an incentive for companies to manage assets so as to lessen such contingent environmental liabilities.

This impact on price - what I shall call the price effect -- is perhaps the most basic way that the market for corporate assets incentivizes companies to comply with environmental laws and regulations. By staying in compliance (or even going beyond compliance) with existing environmental regulations, the firm can get a better price for its assets. The market thus creates a direct financial incentive for the correction of conditions that are potentially problematic given current legal and regulatory requirements.

It is one thing, however, for the market price of asset to incorporate the contingent liabilities (environmental and otherwise) carried by those assets, but quite another for market transactions to somehow actually multiply a firm's incentive to reduce such liabilities. A risk neutral buyer, for instance, will subtract the expected regulatory costs running with an asset from the price it is willing to pay for an asset. This seems to suggest that transactions have a

\footnotetext{
${ }^{13}$ It is an obvious simplification to assume that clean asset carries no environmental liabilities, but this simplification does not cause any loss in generality of the analysis.
} 
neutral effect: whether or not it sells the asset, the firm has to bear the expected liabilities generated by its decisions regarding the environmental management of that asset.

To be more precise, consider an asset (a plant, or piece of real property) with a single source of regulatory risk (a single compliance issue) and suppose that compliance would eliminate that risk in the sense of reducing the probability of regulatory sanction from $\mathrm{p}$ to 0 . Suppose also that a buyer could perfectly and costlessly determine whether or not the seller had complied, and assume for simplicity that compliance costs less than noncompliance (in that $c<p F)$. Under these assumptions, in a competitive market, the seller's discount D would equal 0 if the buyer had complied and $c$ if it had not. Either way, the buyer absorbs the cost of compliance, and the market has a neutral effect (relative the regulatory enforcement system) on compliance. A similar story would obtain if $c>p F$, so that the firm noncompliance is cheaper than compliance. If noncompliance is cheaper for a risk neutral seller, then it also would be for a risk neutral buyer. Hence the expected regulatory cost of the asset to any such buyer is also $p F$. It is this amount that the buyer will subtract from what it otherwise would pay for the asset. Thus regardless of whether the firm retains or sells the asset, it internalizes the $p F$ expected regulatory cost.

B. How Asset Transactions Systematically Enhance Regulatory Compliance Incentives

For several reasons, such transactional neutrality is unlikely to hold. Rather, asset transactions are likely to lead to systematically greater incentives for regulatory compliance.

1. Asymmetric Costs and Benefits of Regulatory Compliance: Regulatory Comparative Advantage as a Cause (and Consequence) of Asset Transactions

The first reason why the market for assets may have a non-neutral effect on regulatory compliance incentives is that unlike my earlier example, the buyer and seller are 
not identical with respect to either their cost of compliance $c$ or their expected fine $p F$.

Compliance may mean a number of things, ranging from major capital expenditures on new pollution control equipment or on upgrading old equipment to increases in annual expenditures on the operation and maintenance of such equipment. ${ }^{14}$ For a number of reasons, firms are likely to differ in their actual cost of compliance.

The first reason is that the cost of capital is not the same for all firms. A fundamental tenet underlying the modern corporate finance theory is that it costs firms more to raise capital externally - by borrowing from banks, or selling bonds or stock - then to raise it internally by using retained earnings. ${ }^{15}$ When regulatory compliance demands large capital expenditures, companies with strong cash flow and retained earnings can obtain such capital more cheaply than companies who have to go outside for capital. External capital providers, moreover, tend to be reluctant to fund projects - such as new pollution control equipment which do not add to cash flow but rather simply reduce the expected regulatory fines facing a company. Finally, small, newer companies without established reputations must generally pay a premium when they attempt to borrow money externally. Thus the cost of capital is likely to vary systematically with firm type, so that smaller and newer firms may have a significantly higher cost of acquiring the capital for regulatory compliance than do larger, more profitable firms.

As a direct consequence of this asymmetry in the cost of capital, larger firms are likely to have a comparative advantage in making initial capital investments required to be in compliance with environmental, health and safety regulations. They also are likely to have an advantage in operations and maintenance expenditures. As confirmed by a substantial

\footnotetext{
14 The same is true for contaminated land, where compliance may require a large upfront remediation investment plus ongoing annual expenses for groundwater monitoring.
} 
body of empirical evidence, there are regulatory economies of scale not only in initial

investments to install, e.g. pollution control equipment, but also in operating and

maintaining that equipment so that it performs as regulations require. ${ }^{16}$ Hence larger firms

may have a significant advantage in the overall cost of regulatory compliance.

Against this cost advantage must be balanced the possibility that the higher visibility of larger entities may also face a higher expected regulatory sanction, $p F$, for being out of compliance. There is evidence that larger entities are much more visible to regulators, and more likely to be the subject of inspections and enforcement actions. ${ }^{17}$ On the other hand, in the environmental area, regulatory fines are set so as to force the company to payback the compliance costs it saved. A company with lower compliance costs would also then face a lower fine. Also arguing for lower expected regulatory sanctions for big firms is evidence that larger firms are also better able to contest and negotiate for lower regulatory sanctions when they are alleged to be in noncompliance. The empirical evidence does not answer the question of how an enhanced likelihood of being enforced against but lower expected penalties given enforcement balance out. My own hunch is that on balance, larger companies face higher expected regulatory sanctions for non-compliance.

Even if this is so, however, size and capital cost advantages are likely to make any given expected regulatory sanction $p F$ carry much more weight with a small company than

15 See Kenneth Froot, David Scharfstein and Jeremy Stein, Risk Management: Co-ordinating Investment and Financing Problems, 48 J. Finance 1629 (1993).

${ }^{16}$ Economies of scale in regulatory compliance have been consistently found in empirical studies going back over twenty years. Most recently, W. Mark Crain and Thomas D. Hopkins, The Impact of Regulatory Costs on Small Firms (U.S. Small Business Administration, RFP No. SBAHQ-00-R-0027, 2001) (available at http://www.sba.gov/advo/research) estimate that all federal regulations (environmental, economic, workplace, and tax compliance) cost firms with fewer than 20 employees nearly $\$ 7,000$ per employee per year, versus $\$ 4,300$ for medium size firms and $\$ 4,500$ for large firms, with an even greater small firm disadvantage in the manufacturing sector. Id. at 3. Indeed, in the manufacturing sector, federal environmental regulations cost small firms almost $\$ 17,000$ per employee, versus $\$ 7,000$ for large firms.

${ }^{17}$ For supporting evidence drawn from the occupational safety and health area, see Ann Bartel and L.G. Thomas, Direct and Indirect Effects of Regulation: A New Look at OSHA's Impact, 28 J. Law \& Econ. 
with a large one. This is because for any given fine or penalty $F$, the smaller is the entity facing it, the more likely is it that the fine would threaten the firm with bankruptcy. For a variety of reasons, including direct transaction costs and managerial incentive issues, bankruptcy is very costly. ${ }^{18}$ What this means is that if a sanction $F$ is large relative to the firm's capitalization, then actual expected cost to the firm of that sanction is not just $p F$--the probability it occurs multiplied by the sanction - but $p F$ plus some amount $B$ representing the costs of financial distress that the fine would trigger. Hence when sanctions that are large relative to the firm's capitalization, the firm acts as if it were risk averse with respect to that sanction, it adds what might be called a "pseudo risk premium" B to the expected fine.

The foregoing analysis suggests that there is likely to be a profound difference between large and small firms in both their cost of regulatory compliance $c$ and in the expected sanction $p F$ that they perceive for non-compliance. There are, to be sure, some small firms that are very efficient in reducing their pollution, and some that enjoy very cooperative relationships with the state and local regulators who are responsible for enforcing in many states for enforcing environmental, health and safety laws. As a general matter, however, one would expect that in effective terms, the regulatory burden facing a small firm is greater than the regulatory burden facing a large firm. That is, if we let the subscripts $s$ and $L$ denote small and large firms respectively, then the regulatory burden

(1985), who found that a firm with 500 employees was 5 times more likely to face OSHA inspection than a firm employing 10 or fewer persons.

Id. At 31. Crain and Hopkins found that environmental and tax compliance costs account for virtually the entire cost disadvantage faced by small firms, while the cost of workplace regulations was roughly constant across different firm sizes, and the cost of economic regulation highest for the largest firms. A lucid explanation of regulatory economies plus supporting evidence from outside the United States is presented in Ian Bickerdyke and Ralph Lattimore, Reducing the Regulatory Burden: Does Firm Size Matter? 27-30, 59-72 (Commonwealth of Australia Industry Commission, Staff Research Paper, December 1997). 
facing the small firm, $R_{s}$, which is equal to $\min \left\{c_{s}, p F_{s}\right\}$ is likely to be such that $R_{s}>R_{L}$, where $R_{L}=\min \left\{c_{L}, p F_{L}\right\}$.

If this is true, then the market for firms and assets may systematically improve regulatory compliance by creating a mechanism whereby such firms and assets are transferred from high compliance cost small firms to low compliance cost large firms. The gain in reduced regulatory compliance cost may not often be among the major reasons for companies doing a transaction. Asset acquisitions by large corporate buyers may often be strategic, in the sense that the buyer is acquiring a plant or facility because it is a relatively cheap way for the buyer to expand or fill a gap in its existing capabilities. Still, the very fact that the large buyer finds it cheaper to buy an existing (built) asset rather than building a new asset tends to suggest that the buyer will have a comparative cost advantage in operating that asset. Especially in heavily regulated industries, where regulatory compliance costs are an important share of total costs, there may be a substantial compliance cost reduction when a large company acquires assets from a small company. In theory, such compliance cost reductions could be an important motive for corporate acquisitions in such industries, and an important social benefit of such acquisitions would be the regulatory cost reductions that they generate.

Of course, lots of corporate transactions involve situations where big firms are selling assets to smaller firms. Unsurprisingly, financial economists have adduced a number of reasons for asset divestitures, ${ }^{19}$ but among the most important is the idea that many asset

\footnotetext{
18 On the costs of financial distress and how they induce firms to reduce the risk of such an eventuality, see Neil A. Doherty, Integrated Risk Management: Techniques and Strategies for Managing Corporate Risk 204211 (2000).

${ }^{19}$ Steven Kaplan and Michael Weisbach, The success of acquisitions, evidence from divesitures, 47 J. Finance 107 (1992) have found that such asset sales often follow a failed acquisition. Lots of other reasons for asset sales have been adduced in the literature, one of the most important being that firms often become too diversified, creating such complexity that their own internal capital allocation decisions become inefficient, and making it very costly to monitor managerial behavior. For prominent contributions to this literature, see, e.g.,
} 
sellers are very large conglomerate firms which have become inefficiently diversified. ${ }^{20}$

Although they represent a sale from a larger to smaller firm, such conglomerate divestitures are consistent with the theory of regulatory comparative advantage. Even though the seller is larger than the buyer, the asset may be such a bad fit with its overall business focus that a smaller buyer actually has a regulatory comparative advantage in owning and managing the particular asset. Perhaps more commonly, a large diversified seller may have managed the asset poorly simply due to lack of focus and inefficient allocation of internal capital to other assets or corporate divisions. In such a case, a smaller buyer may refuse to go ahead with a transaction unless or until a large diversified seller finally uses its neglected comparative advantage in capital cost by fixing various regulatory compliance issues that afflict the asset. In such a case, the asset sale will be a motivation for a large, diversified seller to finally focus on and clean up a particular asset.

\section{Transaction-Motivated Information Acquisition: the Social Value of Due}

Diligence

For buyers and sellers to realize gains form a buyer's comparative advantage in regulatory compliance, the buyer must learn about the regulatory risks that run with the asset, and the cost of reducing those risks (or the expected regulatory sanction for noncompliance). In particular, a buyer must know about the potential source of liability. If the asset is a piece of real property, for example, then if a buyer is to discount her price by the

G.L. Hite, J. Owers and R. Rogers, The Market for Interfirm Asset Sales, Partial Sell-Offs and total Liquidations, 18 J. Fin. Econ. 229 (1987), L. Lang, Andrew Poulson and Rene Stulz, Asset Sales, Firm Performance, and the Agency Costs of Managerial Discretion, 37 J. Fin. Econ. 3 (1995).

${ }^{20}$ Financial economists remain puzzled by the diversification discount, the apparent tendency for large conglomerate firms to trade at a discount relative to matched portfolios of undiversified or "pure play" firms. The most recent empirical work on this question has compared the investment behavior of conglomerate firms both before and after they spin-off or sell assets to become less diversified. For an up-to-date discussion of the literature and interesting new empirical approach, see Gonul Colak and Toni M. Whited, Spin-Offs, Divestitures and Conglomerate Investment (June, 2004 revision) (available at http:/ /

www.research.bus.wisc.edu/twhited/colakwhited.pdf). 
expected cost of complying with laws governing the cleanup of hazardous waste sites (such as the federal Superfund law), she must know whether or not the real property in question is or is not contaminated by hazardous waste.

The most direct way for a buyer to acquire such information would be to ask the seller. But suppose that in market equilibrium buyers know that sellers have only incomplete information regarding an asset's future regulatory costs. If this is so, then by performing its own due diligence review, the seller can acquire information regarding such potential future costs that the buyer does not have. Armed with such information, the buyer will be in a better position to take steps to reduce the extent of such liabilities than was the seller. Hence the due diligence accompanying an asset transaction can itself generate the information that allows the buyer to reduce expected environmental harms generated by the asset.

The obvious question is how it is that a due diligence investigation can give the buyer, who has not operated the asset, better information about the regulatory exposures generated by that asset than the seller already has. The first reason is a variant of the earlier comparative advantage argument. For a mutually beneficial price to exist, the buyer must attach higher value to the asset than does the seller; that is, there must be expected gains from trade. One major (indeed some would say predominant) reason for such gains from transferring control of the asset is because the buyer has smarter, better management and run the asset more efficiently (recall that as I am using the term asset, be an entire firm). A seller that is getting a sub par return from the asset probably has poor management in general, and such poor management generally leads to lots of unknown regulatory problems and risks. Thus the transaction itself may be motivated by the seller's relatively poor 
knowledge and management, so that its own independent due diligence investigation is the only way that the seller can find out about the target asset's regulatory exposure. If, for instance, the seller finds a history of regulatory problems, then it will need to adjust its price by the expected capital and operating costs of bringing a company into regulatory compliance. $^{21}$

The problem is likely to be especially severe when the seller is a firm that has been in financial trouble. A firm facing short-term financial crises will rationally ignore long-term regulatory risks. Indeed, under financial distress, managers serving the interests of equity holders will tend to prefer risky, high variance projects, that effectively transfer risk to creditors, among whom are regulators and common law tort claimants. ${ }^{22}$

Poor seller management is not, of course, the only reason why a buyer may be interested in the seller's asset. The acquisition may be strategic in the earlier sense, and the seller may well be an efficient and well-informed firm. In this case, the seller surely could acquire some valuable information from the buyer simply by asking. However, there would still be a strong incentive for the seller to do its own due diligence investigation of the seller's regulatory compliance situation. The buyer may well not even know what the universe of potential problems are - what to ask about - unless and until it brings in informed consultants to do the due diligence. Moreover, the more information the seller has (and has verified), the better will be its position in bargaining with the seller over price and other terms. These other terms, finally, will importantly include those specifying which risks will stay with the buyer even after the sale. The buyer is in a much better position to bargain

\footnotetext{
21 Alexandra Reed Lajoux and Charles Elson, The Art of M\&A Due Diligence 319 (2000). ${ }^{22}$ For this basic result in the theory of corporate risk management, see Neil A. Doherty, Integrated Risk Management 334-335 (2000).
} 
over such terms if it has independently acquired information regarding what might or might not be indemnified. ${ }^{23}$

3. Seller Disclosure: The Common Law of Fraud and the Potential for Advantageous Selection

a) The Relationship between the Seller's Common Law Duty to Refrain from Fraud and the Buyer's Due Diligence Incentive

In discussing buyer due diligence, I presumed that the seller typically believes that the buyers is only imperfectly informed about the asset's regulatory exposure. Of course, since the seller has actually been operating the asset, it would seem that even a poorly informed seller would have some information about the regulatory exposure generated by the asset, and that the easiest way for prospective buyer gain knowledge of the environmental issues pertaining to a particular asset would be to simply ask the seller. Any knowingly or intentionally false assertions by the seller - such as a false statement that land is free from contamination by hazardous waste, or that a plant is in compliance with all relevant air and water pollution permits - would be fraudulent and would constitute grounds for setting aside the transaction. ${ }^{24}$ A commercial seller, however, has no duty to investigate to determine the actual extent of potential environmental liabilities running with the asset that it is selling, and therefore if posed a general question "are there any environmental problems at this site (or plant, or whatever)" can avoid fraud simply by revealing the ones that she does know about. Standing alone, the common law duty to avoid fraud actually tends to create an incentive for a commercial seller to remain ignorant of the potential liabilities attached to

\footnotetext{
${ }^{23}$ For these points, see Denzil Rankine, Graham Stedman and Mark Bomer, Due Diligence: Definitive Steps to Successful Business Combinations 183 (2003)

${ }^{24}$ To be more precise, under the Restatement (Second) of Contracts \$164(1), “if a party's manifestation of assent is induced by either a fraudulent or material misrepresentaion by the other party upon which the recipient is justified in relying, the contract is voidable by the recipient."
} 
ownership of her asset.

But the common law duty for the seller fraud does not stand alone. It creates an incentive for buyers to ask about potential environmental problems, and the answer (or nonanswer) that a seller gives is an important determinant of how much the buyer spends in its due diligence investigation. There are other obvious determinants of a buyer's due diligence effort - such as the size of the transaction and the buyer's ex ante perception of the size of the potential regulatory risks carried by the asset. The seller, however, can have an important effect in determining the buyer's perception of the need for due diligence and on the regulatory risk surrounding the transaction. That is, a crucial determinant of the size of the transaction costs that they buyer incurs to assess the regulatory risks of a transaction is the buyer's perception of the completeness and accuracy of the information pertaining to those risks revealed to it by the buyer.

It is here - in generating information for the buyer about the seller's "type" - that the common law duty to avoid fraud does its most important work. The common law defense of fraud forces a truthful seller answer to the buyer's general 'is there anything we ought to know" question. The more knowledgeable is the seller about the environmental and regulatory exposure attached to the asset that it is selling, the more informative will be its answer to such a general question. The more informative is the seller's disclosure, the less the buyer needs to worry about there being residual, undisclosed risks, and the lower will be the amount that the buyer spends on its own independent investigation of the asset.

b) The General Incentive for Seller's to Acquire and Disclose Information Regarding Environmental Risks

This effect is more general. However it is that the seller is able to reveal itself to be 
knowledgeable regarding its regulatory risks - whether through transactional disclosure, or previously acquired reputation - the incentive to acquire gain such a market identification can magnify the incentives for risk minimization otherwise created by the regulatory enforcement system. Because they spend less in doing independent investigation when transacting with sellers identified as such "good" types, buyers' transaction costs when dealing with such sellers will be less than when they are dealing with relatively careless, ignorant sellers. With lower transaction costs, the buyer is wiling to pay more when dealing with a "good" seller type than with a "bad" seller type.

To see this most clearly, consider the extreme case of two seller types: an informed seller, who has perfect knowledge of all regulatory risks pertaining to a particular asset, and an uninformed seller, one with no knowledge of any such risks. Suppose further that the buyer can acquire perfect knowledge by spending an amount $T$ on due diligence investigation. When dealing with an informed seller, the buyer acquires expected regulatory costs of $\min \{c, p F\}$; when dealing with the bad seller, the buyer acquires the same regulatory costs, but also must incur the cost $T_{b}$ of identifying them. The net value of the asset is higher to the buyer when dealing with the good seller. That is, a buyer will discount the bad seller's asset by $\left[\min \{c, p F\}+T_{b}\right]$, while discounting the good seller's asset only $\min \{c, p F\}$

The argument is not quite finished, for an informed seller will typically have incurred some cost to become knowledgeable about its potential regulatory exposure. If we call this $\operatorname{cost} T_{s}$, and the good seller bears this entire cost, then it is true that her gain from selling the asset will be less the amount $T_{s}$. Thus for the good seller to be better off than the bad seller, it must be that $T_{s}<T_{b}$. With most regulatory risks, this would seem to be likely. Knowledge of many such risks - such as occupational, health, safety and environmental 
issues - is likely to be much cheaper to acquire through day to day operational history than by a one-shot due diligence investigation. Indeed, for a potential buyer to acquire the same sort of knowledge of a plant or facility's regulatory status as a seller who keeps and analyzes accurate data on its health, safety and environmental practices would seem in many cases to be prohibitively costly.

The information cost savings that benefit knowledgeable asset sellers likely underestimates the transactional benefits gained by such sellers. Especially as the complexity of the potential regulatory exposures increases, it is unlikely that the quality of the information gained by a buyer's due diligence investigation can ever be as good as the information possessed by a well informed seller. Importantly, by “information” I mean sources of potential regulatory exposure. Given the nature of the asset, there are certain foreseeable risks. For instance, any reasonable buyer should foresee that chromium wastes might contaminate a property formerly used by a chrome plating plant. Its due diligence investigation should attempt to discern whether there are indeed such wastes, and if they are present on the property, to estimate the expected regulatory costs associated with those wastes. Other risks, however, may not be so easily anticipated and estimated by an outside buyer. The current owner of a plant may, for instance, may have learned that various modifications made to the plant have made it more costly to control pollution than would typically be true of such a plant. Even if its due diligence revealed the modifications, a buyer might not know to ask about the effect of these modifications on pollution control costs.

When knowledge of regulatory risks is asset specific in this way, a well-informed seller will have better information regarding regulatory risk than will even a careful buyer. This superior knowledge creates an additional incentive for "good" environmental management practices, such as a regular program of thorough internal environmental audits that generate 
such knowledge. This incentive comes about because an asset purchased from a firm known to be "good" in this sense has less residual downside uncertainty - uncertainty about unknown risks remaining after due diligence -- to the buyer than does the same asset when purchased from a "bad" type firm.

To see why this is so, recall that a bad type firm has very little knowledge of regulatory risks beyond that which the buyer can obtain for itself by doing due diligence. To simplify, assume that the bad type firm has no comparative advantage in regulatory risk identification versus an outside buyer. But this just means that neither the seller nor the buyer has complete information regarding the regulatory risks carried by the asset in question. Whatever risks have been identified by the buyer, it will rationally realize that there may well be other risks that neither it nor a bad seller know about. In ways that I explain in more detail below, the seller will discount its price not only by the expected regulatory burden $p F$ that it has discovered through due diligence, but also by an additional amount, which we may call $U$, for the unknown, undiscovered burdens.

Now compare the situation confronting the buyer when it is dealing with a good firm. By disclosing the risks that its own management practices have revealed, the good seller not only exploits its comparative advantage in risk identification to lower the total transaction costs of the deal - as described earlier - but also assures the buyer that the probability of additional regulatory risk, unknown to either buyer or seller, is very low. In other words, because a good seller knows a lot more about its regulatory exposure than does a bad seller, when it states that the only risks are $\mathrm{x}, \mathrm{y}$ and $\mathrm{z}$, with an overall expected cost of $\min \{\mathrm{c}, p F\}$, the seller will perceive a very slight chance that there is any other, unknown source of environmental liability. When a bad seller reveals $\mathrm{x}, \mathrm{y}$ and $\mathrm{z}$, by contrast, the buyer, knowing that the seller does not know very much about what the regulatory risks really are, will 
assume that there is a very high probability that there are a number of other potential sources of regulatory cost. Hence the buyer will discount its purchase price by a smaller amount when dealing with a good seller than when dealing with a bad seller.

What has been demonstrated is that if "good" well-informed sellers can credibly identify themselves as such, then the market for assets itself can create an incentive for a company to become informed regarding the regulatory burden carried by those assets, even if the law does not require that it become informed.

c) Why Selection in Regulatory Risk Disclosure is More Likely to be Advantageous than Adverse

I have argued that asymmetric information between buyers and sellers creates an incentive for sellers to become well informed regulatory risks and to reveal these risks so as to reduce the buyer's due diligence transaction costs and the buyer's price discount for unknown but potential liabilities. This is not the standard account of the effect of asymmetric information in asset markets. On that account, asymmetric information creates a potential adverse selection problem in which "bad" sellers with dirty, risky assets drive "good" sellers out of the market.

This adverse selection problem does not affect the validity of my analysis. To understand why, we must recall when and why adverse selection would occur with respect to regulatory risk. Adverse selection occurs when buyers cannot ascertain the quality of the good or service that they are purchasing prior to purchase. If, to be more specific, buyers cannot accurately discern the actual regulatory risk associated with a particular asset, and instead know only the general distribution of regulatory risks for assets of that type, then their discount $D$ will be equal to the expected or average regulatory risk for assets of that type. But then sellers who have spent an above average amount in reducing such risks (or 
have simply been more productive than average in such expenditures) will not be adequately rewarded by the market for their efforts. This would seem at the very least to cut the incentive to be such a good environmental performer. At the worst, it might jeopardize the market in assets, as firms that have reduced environmental risks below the average refuse to sell with such a drastic regulatory risk discount, leaving even worse performers, and so on, until the market collapses.

This form of adverse selection can occur, however, only if buyers are not able to independently discover regulatory risks before buying the asset. In my model, by contrast, I assume that through due diligence, buyers are able to discover all regulatory risks that the seller has not actively taken steps to conceal from such outside investigation. As argued earlier, differential costs of fixing regulatory problems are, if not often a primary motive, at least benefit of many asset transactions: the market tends to move assets with high regulatory compliance burdens to firms best situated to fix those problems. What distinguishes "good" from "bad" asset sellers on my analysis is not the extent of the regulatory liabilities carried by their assets. It is whether or not the firm has become informed as to the extent of its potential regulatory exposure, so that it can reveal that information to potential buyers, cutting a buyer cost and need to do due diligence, and its discount for undiscovered potential liability. A bad seller in my terms can conceal its type in order to get the same price that a good seller gets only if it either fabricates regulatory compliance data that it reveals to the buyer or if it actively takes steps to reveal data indicating lots of regulatory problems. But under the common law of fraud, both outright fabrication and active concealment constitute fraud ${ }^{25}$, and such transactions will not stand. Thus in the situations I am

\footnotetext{
${ }^{25}$ For example, a purchaser can set aside a real estate transaction on grounds of fraudulent concealment by showing its detrimental reliance upon a material fact or defect not readily observable to the purchaser, which was deliberately concealed by the seller. See Black v. Cosentino, 117 Ohio App.3d 40, 689 N.E.2d 1001, 1002
} 
considering, the common law of fraud effectively precludes adverse selection.

This may be criticized as overly ambitious. For while it is true that a seller is guilty of fraud if it takes steps to actively conceal information from a buyer's due diligence, common law fraud is effective only if it can be discovered and the transaction undone. This is likely with regulatory risks, however, for especially when a large firm acquires an asset from a smaller firm, once it owns and begins to operate the asset, it is likely to discover whether the seller misrepresented the extent of the asset's potential regulatory liabilities. That is, even if the seller has fooled the buyer into thinking that it was well-informed and accurately disclosed potential regulatory problems, it will not take the seller long after acquiring ownership to determine whether this was in fact the case.

4) Why Regulatory Comparative Advantage Likely Dominates Regulatory Avoidance by Outsourcing

By outsourcing, I mean those transactions in which a firm sells or closes a division that performed a particular operation (or set of operations), and henceforth contracts with an outside firm for those operations. Examples of operations that firms have outsourced include not only various labor intensive manufacturing processes, which in industries from apparel to automobiles have been outsourced to factories in the developing world, but also relatively land intensive activities, such as poultry and swine growing, which large processors have outsourced to small, independently owned landowner-growers. Outsourcing is primarily driven by economic comparative advantage. American apparel firms design their

(1996); Weintraub v. Krobatsch, 64 N.J. 445, 317 A.2d 68, 74 (1974); White Consol. Industries, Inc. v. Westinghouse Elec. Corp., 179 F.3d 403 (6 $6^{\text {th }}$ Cir. 1999) (involving fraudulent concealment in contaminated property acquisition). 
products in the U.S. but have them sewn in China, where unskilled labor is cheaper. ${ }^{26}$

American chicken and pork processing firms specialize in the selective breeding of poultry and swine and in the development of feeds and the design of rearing facilities, but avoid the costs of land ownership by contracting out the actual raising of the animals to independent growers. ${ }^{27}$ Manufacturers that do not produce sufficient volume to justify having their own internal metal finishing and plating operations contract them out to independent metal finishers, who perform a variety of different plating operations for a variety of different types of manufacturing. ${ }^{28}$

While the realization of economic comparative advantage would seem to be the primary reason for outsourcing in most cases, it has been argued that firms may often outsource as a way or reducing their expected environmental regulatory burden, so that as a transactional type, outsourcing may actually lead to reduced incentives for environmental performance. $^{29}$ On this argument, compliance can be avoided by shifting activities to smaller firms that are so thinly capitalized that they are immune to the threat of ex post liability and so small that they are exempt from regulatory requirements that apply to larger firms.

Although superficially appealing, the foundations of this argument are weak. It is true that under the common law, a firm that buys assets from another firm does not generally acquire liabilities arise from the seller's prior operation or use of those assets. ${ }^{30}$ Hence if the asset is a piece of real property that the seller contaminated with hazardous waste from its

\footnotetext{
${ }^{26}$ [add citation to Chinese apparel industry]

27 [add citations to articles describing the typical processor-grower contract in terms of who does what] ${ }^{28}$ For a description of the independent, "job shop" metal finishing industry, see Jason Johnston, The Promise and Limits of Voluntary Management-Based Regulatory Reform: An Analysis of EPA's Strategic Goals Program, in Leveraging the Private Sector _ (Cary Coglianese and Jennifer Nash, eds., forthcoming, RFF Press, 2005).

${ }^{29}$ For such an argument and the term regulatory avoidance, see Vandenbergh, The Private Life of Public Law, supra note _ at 30-32, 56-57.

${ }^{30}$ For this basic proposition and an overview of the law of successor liability, see Marie T. Reilly, Making Sense of Successor Liability, 31 Hofstra L. Rev. 745 (2003).
} 
operations, then purely as a matter of the common law, a firm buying the property would not ordinarily become liable for the harm caused by that contamination. Thus it would seem that even if it has a regulatory comparative advantage in the form of lower costs of site cleanup, a larger, buying firm would have no incentive to eliminate the contamination. However, if the liability stays with the seller, the seller may seek to cover its cleanup cost in the purchase price, and if the buyer is indeed the cheaper site cleaner, then both buyer and seller would be better off if the seller agreed to assume the seller's cleanup liabilities, getting in exchange some substantial fraction of the difference in cleanup costs.

This rather straightforward application of the Coase Theorem ${ }^{31}$ shows that the common law rule limiting successorship liability does not itself eliminate the transactional incentive for efficient site cleanup. Even with no successor liability, the parties have an incentive for the cheaper cost - bearer to incur the cost of cleanup. This is true only, however, if the common law actually creates an incentive for the seller to incur the cleanup cost. As with all common law schemes, the seller will only have an incentive to do costly cleanup if the cost of cleanup is less than its expected sanction if it does not do the cleanup. If, however, the seller firm is bankrupt, or more generally has assets that are much smaller than the sanction for failing to cleanup, then it is effectively judgment proof, and the specter of potential common law liability will not induce it to incur cleanup. If the seller has no incentive to cleanup, and the buyer assumes no liability for the seller's failure to cleanup, then neither the buyer nor the seller will have an incentive to cleanup the contaminated site.

The judgment proof problem would seem to be much worse even than this, for it creates an incentive for larger firms to outsource dirty, liability-triggering activities to small, thinly capitalized firms. That is, insofar as common law incentives are generated by ex post

${ }^{31}$ Ronald Coase, The Problem of Social Cost, 2 J. Law \& Econ. 1 (1960). 
liability, the ability of firms to escape ex post liability by having judgment proof outside firms conduct dirty, liability-triggering activities means that firms can use such outsourcing deals to eliminate common law incentives for environmental performance.

Far from being ignorant of or condoning this strategy, however, common law rules are designed to preclude it. While it is true that employers are not generally liable for the torts committed by their independent, outside contractors, ${ }^{32}$ there is an important exception, under which the employer remains liable when the contractor is employed to do work "involving a special danger to others which the employer knows or has reason to know to be inherent in or normal to the work." 33 Under the common law, an employer has a nondelegable duty to exercise due care when performing an inherently or abnormally dangerous activity, and the employer cannot discharge this duty by hiring an independent contractor. ${ }^{34}$ While this rule does not make big corporations strictly liable for the environmental harms caused by every small firm with whom they deal, it clearly does justify the imposition of liability upon a finding that the larger firm was in a true independent contractor relationship with the smaller firm, and therefore able to influence or control its actions. ${ }^{35}$ The effectiveness of this common law approach in preventing firms from externalizing harms by hiring judgment proof independent contractors is in fact well demonstrated by the fact that courts have engrafted it upon the federal Superfund law. ${ }^{36}$

It may be objected that outsourcing is used not to eliminate common law liabilities, but rather regulatory compliance burdens. It is true that public regulation does not rely upon ex post damages as a way of changing corporate behavior. Command and control

\footnotetext{
${ }^{32}$ See Richard Epstein, Cases and Materials on Torts 465 (6 th $^{\text {ed. }}$ 1995).

${ }^{33}$ Restatement of Torts $₫ 427$.

${ }^{34}$ Bahlre v. Exxon Corp., 678 A.2d 225, 231 (N.J. 1996).

${ }^{35}$ Bahlre v. Exxon, supra note _ at 232.
} 
regulation directly mandates that firms do certain things to reduce or avoid polluting the environment, and firms may face severe sanctions for failing to comply. Indeed, for this reason one may view public regulation as a response to the judgment proof problem.

Still, command and control regulation also imposes costs, and small firms may have great difficulty in bearing these costs while remaining profitable. Insofar as such small firms are important not only politically but also economically, as an engine for job creation and economic growth, Congress has generally treated them more leniently under the major federal environmental regulatory statutes. There are countless examples of this phenomenon. Small industrial firms that discharge into small publicly owned wastewater treatment facilities are not subject to federal Clean Water Act standards. ${ }^{37}$ Small firms do not need to report their toxic releases under the Toxic Release Inventory. ${ }^{38}$ Major sources of air pollution are treated differently minor sources. ${ }^{39}$ More generally, command and control environmental regulations vary across industry categories and subcategories, and under virtually all command and control environmental regulatory statutes, regulators are told to consider the costs to an industry category or subcategory of compliance with proposed regulations, and the economic dislocations - in terms of lost jobs, and firm closings - that alternative regulations would entail. ${ }^{40}$ Because, as I discuss momentarily, regulations are more costly to small firms, and more likely to imperil their economic viability, the actual regulatory process has generated a regulatory system in which smaller enterprises generally face different, and more lax regulatory requirements than do larger enterprises. In theory,

\footnotetext{
${ }^{36}$ See, for example, United States v. Aceto Agricultural Chemicals Corp., 872 F.2d 1373 (8 ${ }^{\text {th }}$ Cir. 1989)(looking to common law to fashion test for liability under Superfund as an "arranger.")

${ }^{37}$ [cite to pretreatment standards]

${ }^{38}$ See Vandenbergh, supra note _ at 56-57.

39 [add citation to relevant sections in CAA]

${ }^{40}$ For examples of such statutes, see Jason Scott Johnston, Tradable Pollution Permits and the Regulatory Game, in Thirty Years of Market Based Instruments (Jody Freeman and Charles Kolstad, eds., Oxford University Press, forthcoming, 2005).
} 
such a system enables large firms to effectively lower their environmental performance by outsourcing environmentally harmful activities to small firms.

In practice, the incentive for firms to unload their regulatory obligations by vertically disintegrating their dirty operations is likely to be limited. If the only reason for such disintegration is to eliminate regulatory obligations by shifting the regulated activity to a smaller and less intensively regulated firm, then a larger, disintegrating firm must balance its reduced regulatory compliance costs against the increased contracting costs that it will now have in dealing with an outside firm, versus an internal division. Only if regulatory compliance savings were substantial would a firm incur the costs of outsourcing. But if regulatory compliance costs are substantial, then it is likely that the activity (e.g. factory farming) generates lots of pollution and has high regulatory and public visibility, in which event outsourcing will itself generate political, legal and regulatory pressure to shift regulatory obligations back to the disintegrating larger firm. ${ }^{41}$ In other words, by trying to outsource away their regulatory compliance costs, firms may end up triggering a political and regulatory reaction that puts an even tougher regulatory burden on them.

More fundamentally, in the universe of asset transactions, regulatory comparative advantage is likely to be of much greater significance than is regulatory avoidance. The reason is that regulatory comparative advantage arises from a confluence of economic and regulatory incentives. Efficiency gains are the primary reason for private asset transactions, and the same things that make one firm a more efficient owner of an asset - such as superior management and greater access to internal capital - also make that firm a superior environmental manager of that asset. A comparative advantage in regulatory compliance thus usually goes with a similar comparative advantage in economic management.

${ }^{41}$ [For a classic recent example, discuss the move to move liability back to poultry processors.] 
Regulatory avoidance, by contrast, involves the transfer of assets to smaller, less efficient ownership merely to get the benefits provided by a regulatory regime that gives special treatment to small business. Such transactions involve a deliberate loss of economic efficiency for the sake of spurious regulatory compliance cost savings. Rather than a phenomenon that has serious implications for how asset transactions are regulated, regulatory avoidance is, I believe, merely a symptom of a much larger and more complex problem, which is the differential treatment of large versus small enterprises in federal environmental regulation.

\section{Empirical Implications and Evidence for the Existence of a Transactional Multiplier}

1. Empirical Implications

Empirically, one would expect that just as they are likely to enjoy a comparative advantage in regulatory compliance cost, so too will large firms have a comparative advantage in lower costs of becoming "good" asset sellers who are well informed regarding regulatory risks and compliance status. The reason is that it is costly to gain information about how and what regulations require, just as it is to comply with those regulations. Economies of scale are just as likely in acquiring information about regulatory obligations as in meeting them. For instance, establishing a firm-wide environmental management system (EMS) designed to improve the firm's knowledge of its environmental issues involves up front, fixed costs, as well as ongoing expenses on monitoring and auditing. As with any fixed cost, there are likely economies of scale in establishing and operating such systems. Small firms, moreover, may not even realize that such a system is even required. Recent survey evidence from Great Britain, for example, shows that $86 \%$ of small businesses did 
not even think that their operations had an environmental impact. ${ }^{42}$ Unsurprisingly, only 9\% had conducted an environmental assessment, and only $6 \%$ had a certified environmental management system.

If small firms are indeed relatively ignorant of their impact on the regulated environment and at a cost disadvantage in acquiring information regarding their regulatory risks and compliance status, then the incentive to gain such information to reduce transaction costs and discounts for residual unknown is likely to be most significant when large firms are asset sellers. There is thus a kind of market duality: large firms are likely to have lower compliance costs and stronger compliance incentives, which means that large firms have an advantage as asset buyers; by the same token, large firms are likely to be much more likely to be aware of and able to cheaply signal their knowledge of existing regulatory risks, which gives them an advantage as asset sellers.

\section{Evidence}

The ideal evidence set to test my hypotheses regarding asset transactions as a source of heightened incentives for environmental performance would consist of as large sample of assets (land, firms, parts of firms), with data on the environmental performance of those assets both before and after their sale, as well as data on the relative size of the buying and selling firms and other observable variables that might be expected to influence changes in environmental performance. I do not, as yet, have such systematic data. The data I can present here are, admittedly, much more anecdotal and indirect. Yet they do indicate the potential importance of asset transactions as regulatory drivers, and the value of attempting more systematic empirical work in the future.

\footnotetext{
${ }^{42}$ See 2002 Net Regs Benchmarking Survey, How Green are Small Businesses? 5 (2002) (available at www.environment-agency.gov.uk/netregs. T.D. Hopkins, Profiles of Regulatory Costs (Report to the U.S.
} 
The American merger and acquisition market is vast. Even in the relatively depressed market that has followed the bursting of the dot-com bubble, there were 5742 mergers and acquisitions in 2002 , valued at over $\$ 333$ billion. ${ }^{43}$ Deals involving public companies are only a fraction of the total number of deals, but public companies must file various acquisition agreement documents with the SEC, and a recent study has found that of the more than 1000 such agreements filed in 2001 , over 76 per cent contained environmental provisions. ${ }^{44}$ Anecdotal evidence suggests that regulatory comparative advantage may often by a significant rationale driving deals. During the 1990's, for instance, Allied Waste Inc. grew at spectacular rates, acquiring small solid waste landfills across the United States. Those acquisitions were financed primarily by the sale of high yield debt obligations. Given the obvious environmental risks and liabilities attendant in the business of owning and operating solid waste landfills, Allied had to assure potential buyers of bonds that Allied had its environmental act together. Through a rigorous pre-acquisition due diligence and post acquisition monitoring program, it did just that. ${ }^{45}$

The market for secured financing may impose even greater pressure for improvements in environmental performance. For instance, because secured commercial lenders typically securitize and sell their commercial loans, they are intensely interested in having loan portfolios that are easily marketable. The existing rating system used to determine the prices of such portfolios employs a series of discrete categories (or grades). ${ }^{46}$ To get the highest grade, and therefore price, with a minimum of transaction costs, lenders have a strong incentive to put together portfolios which are free of complicating issues that

S.B.A., 1995) found that 40 per cent of 340 small businesses surveyed did not fully comply with most regulations, with the reason most often being ignorance of the rules.

${ }^{43}$ See www.mergerstat.com. In 2000, the peak year, there were 10864 deals worth $\$ 1.83$ trillion.

${ }^{44}$ Vandenbergh, supra note at 17.

${ }^{45}$ [find support; perhaps ask JS]

${ }^{46}$ [add cite; ask Georgette] 
diminish the potential value of the security interest, the land, buildings and or/facilities underlying the loans. In order to offer such a clean, easily marketable commodity, lenders have an incentive to simply avoid companies with large potential environmental liabilities.

Although there is no way to put a dollar estimate on the amount of actual environmental cleanup triggered by the pressure imposed by debt markets, the market for land does allow one to get a sense of the potential magnitude of such efforts. Passed in 1980, the federal Superfund law (the Comprehensive Environmental Response and Liability Act, CERCLA) imposes liability that is strict, retroactive and joint and several. Under CERCLA, not only those who generated or disposed of hazardous waste but also those who buy contaminated properties may be held liable for cleanup costs which typically run into the tens of millions of dollars. ${ }^{47}$ Throughout the 1990 's, CERCLA had a profound deterrent effect, not only in causing many land-related deals to fall through, ${ }^{48}$ but in creating an incentive for companies to avoid generating hazardous waste in the first place. ${ }^{49}$ During this period (1991-1996), the amount of hazardous waste generated by the largest hazardous waste generating firms dropped $30 \%{ }^{50}$ CERCLA's impact promises to continue far into the future. Under 1986 and 2002 amendments to that law, those who acquire potentially contaminated properties are insulated from potential liability for cleanup costs (as an "innocent purchaser" or "bona fide prospective purchaser" under the law) if and only if the property buyer has performed "all appropriate inquiry" to determine the presence of

\footnotetext{
${ }^{47}$ [add cites]

${ }^{48}$ Environmental Issues Kill More Corporate Real Estate Deals than Expected, 7 Envl. Site Assessment Report 1, 4-7 (October, 2002)(survey finding that more than one in three corporate senior financial executives had had a real estate deal fall through due to an environmental problem).

${ }^{49}$ See Michael B. Gerrard, Property Trading: The Pervasive Impact and Environmental Promise of Implicit Economic Incentives, Draft p. (paper presented at UC Santa Barbara Workshop, "Twenty Years of Market-Based Instruments for Environmental Protection: Has the Promise been Realized?, August 23-24, 2003).

${ }^{50}$ Gerrard, supra note _ at 4.
} 
contamination on the property (meaning that they buyer has done a site assessment). ${ }^{51}$

Especially for acquisitions of industrial property, lenders will agree to finance the acquisition

only if such a site assessment is done, and such an assessment is required for the borrower to be able to obtain environmental insurance on the property. ${ }^{52}$

Unsurprisingly, environmental site assessment has become a thriving business, with Phase I environmental site assessments recently averaging 250,000 per year in the United States. ${ }^{53}$ Given the average Phase I cost of $\$ 2,000,{ }^{54}$ the specter of potential CERCLA liability is indirectly responsible for causing at least $\$ 500$ million per year to be spent on

\footnotetext{
${ }^{51}$ The most recent relevant amendments are contained in the Small Business Liability Relief and Brownfields Revitalization Act of 2002, H.B. 2869. I discuss these amendments in more detail infra, at pages _ to _. For a short description, see Brownfields and the new CERCLA Amendments, 7 Environmental Site Assessment Report 1 (November, 2002).

${ }^{52}$ Banks have become increasingly aware of the potential for environmental risk exposure to impact their own stock market valuation, and are especially concerned about the quality of environmental site assessments done for securitized loans. See Banking Community Makes it Clear: Stricter Due Diligence Fueled by Credit Risk Fear, 7 Environmental Site Assessment Reports 14 (Sept. 2002). See also Banks Provide Perspective on Property Environmental Due Diligence, 6 Environmental Site Assessment Report 1 (August 2001); Environmental Due Diligence Now Institutionalized in Banks, 3 Environmental Site Assessment 1 (August 1998). Lenders generally both conduct environmental due diligence and also require insurance against defaults that arise due to environmental liabilities on securitizing properties. See Environmental Insurance vs. The Phase I, 3 Envl. Assessment Reports 1 (Nov. 1998); Environmental Insurance: Another Business Tool to Help Close Deals, 6 Envl. Assessments Reports 1 (Jan. 2001). For some of the issues that arise with regard to such policies, see Rating Agencies Indentify Issues with Secured Creditor Environmental Insurance for Securitization Transactions, 4 Envl. Assessment Reports 1 (1999).

${ }^{53}$ As succinctly set out by Philip L. Comella, Acquiring or Selling the Privately Held Company, 2004 ENVIRONMENTAL ISSUES AND LIABILITY CONSIDERATIONS Practising Law Institute, Corporate Law and Practice Course Handbook Series PLI Order Number 3097 (JuneJuly, 2004), site assessments are typically done in phases:

a) A Phase 0 is research conducted without visiting the site.

b) A Phase I generally entails a site walkover, owner interview, fire insurance map review, title search, and public record review, including UST information. The American Society for Testing Materials (ASTM) issued guidelines for conducting Phase 1 assessments in 1993 and then updated them in 1997 and again in 2000. I discuss these in more detail infra at _.

c) A Phase II assessment is tailored to site specific conditions and usually entails subsurface investigation. See also Dianne P. Crocker, Moving Beyond Phase I to Phase II, 7 Environmental Site Assessment Report 1 (January, 2002). For recent monthly data on the number of Phase I assessments, see Market Radar, 9 ESA Report 2 (July 2004).

${ }^{54}$ See Market Radar, 9 ESA Report 2 (July, 2004).
} 
environmental assessment, ${ }^{55}$ and likely many times that amount in actual environmental cleanup. $^{56}$

E. Adding Business Realism: External Debt and Equity Financing

My discussion thus far has assumed away financing issues, essentially assuming that a buyer firm uses its own money to buy the asset (that is, more precisely, the firm financing the asset acquisition on internal capital markets). I've also assumed that regulatory risks are borne solely by an asset buyer and seller, rather than being at least partially borne by a third party insurer. These assumptions, I would maintain, are realistic for asset acquisitions that are small relative to the capitalization of the acquiring firm. But even large buyers often resort to external private debt or equity financing when they are acquiring (or merging with) large companies. The question explored in this section is whether the transactional incentives for enhanced environmental performance uncovered by the analysis thus far are likely to remain even when one takes more explicit account of how such transactions may be financed.

1. External Debt Financing and Scrutiny for Catastrophic Risk

To quickly summarize the earlier analysis, asset transactions are likely to generate improved incentives for environmental regulatory compliance because buyers likely have a

\footnotetext{
55 Phase I assessment is often followed up with Phase II assessment and, in the case of some especially cautious buyers, groundwater sampling and other testing prior to acquisition.

${ }^{56}$ See Gerrard, supra note
} 
comparative advantage in regulatory compliance, and the transactional event itself generates incentives for both buyers and sellers to become informed regarding potential regulatory risks and costs. The most basic effect of the availability of external capital markets - either debt or equity - is to enhance transactional market efficiency by allowing firms run by better, more efficient managers of assets to obtain control of those assets even when they do not have the internal capital to do so. This is indeed the basic logic behind the efficiency of leveraged buyouts in general. Regulatory risk, after all, is just one of many kinds of risks that a company must deal with. There are operating risks (as when a plant breaks down), financial risks (due, for example, to exchange rate variations) and, perhaps most fundamentally, market risk regarding both demand for the product produced with the asset and the cost of production. ${ }^{57}$ To the extent that external capital markets operate efficiently, to fund managers who are good at dealing with the whole range of risks faced by the firm, they operate also to promote the regulatory efficiencies I have argued for earlier.

The exception to this generally sanguine analysis applies to what may be called catastrophic regulatory risks. Most regulatory risks - such as obtaining proper permits, and properly maintaining existing pollution control equipment - are basically a form of operating cost, and one that may be relatively certain. Other kinds of regulatory risks - such as the possibility that regulators will demand the expenditures of hundreds of millions or even billions of dollars worth of new pollution control technologies, or the risk of finding that real property is contaminated and that regulators will order tens or hundreds of millions of dollars in cleanup expenditures - may well be catastrophic, in the precise sense that they far exceed the present value of the asset. While I discuss the general implications of catastrophic

\footnotetext{
${ }^{57}$ For a discussion of the various sorts of risks facing non-insurance firms, and how firms must consider the entire range of risks in devising risk management strategies, see Doherty, Integrated Risk Management, supra note _ at 268-280.
} 
risk for the operation of the transactional multiplier in more detail below, the key point for present purposes is when a loss is so large that it wipes out the value of the underlying asset, equity owners have every incentive to walk away form the asset, leaving it for creditors to claim. Thus it may seem to follow that because equity owners' liability is limited by the amount of their equity ${ }^{58}$, when they engage in heavily leveraged asset transactions, they will have a much weaker incentive to investigate for such catastrophic risks than my earlier analysis implied.

To make this implication, however, is to forget that lenders will be especially concerned to discern the potential existence of such catastrophic regulatory risks that run with assets whose purchase they are financing. The prospect of equity holders walking away and leaving banks and other debt providers holding worthless assets should make such debt providers especially concerned to do their own due diligence investigation, one that is focused especially on such catastrophic (as opposed to operating) regulatory risks. Thus rather than cutting the regulatory benefits of asset transactions, the expansion in investment facilitated by external debt markets should increase the degree and specialization of due diligence by bringing a player which is especially concerned with the particular category of catastrophic regulatory risk.

The available evidence strongly supports this prediction. Banks become very attuned to potential environmental regulatory risks carried by properties the securitize their loans, and commonly demand environmental assessments not only of Superfund-related hazardous waste contamination but also of environmental regulatory issues more generally. ${ }^{59}$ Lenders also demand environmental insurance against default caused by the realization of

\footnotetext{
58 This is just the rule of limited shareholder liability, as stated, for example, in Frank H. Easterbrook and Daniel R. Fischel, Limited Liability and the Corporation, 52 U. Chi. L. Rev. 89, 89-90 (1985).

${ }^{59}$ See sources cited supra at note _.
} 
environmental risks that destroy the value of such securitizing real estate. ${ }^{60}$ Finally, the terms of loan agreements typically contain provisions that give lenders the right to monitor their borrowers' environmental compliance, and which make borrower noncompliance a default of the loan. ${ }^{61}$ Indeed, one recent study has found that of a sample of 1500 credit agreements filed with the SEC, more than 70 per cent included such environmental provisions. ${ }^{62}$

2. Why Private Equity Likely on Balance Enhances the Market Multiplier

Private equity capital comes primarily in the form of investments by venture capital (VC) and leveraged buyout (LBO) firms. ${ }^{63}$ These firms are typically organized as limited partnerships in which institutional investors (such as pension funds and university endowments) and wealthy individuals are limited partners who promise to supply capital to general partner fund managers for a fixed time period (typically five years), in exchange for the general partners' promise to return capital over similarly fixed (but generally longer, ten year) time period. ${ }^{64}$ During the 1990's, U.S. investments in such firms grew spectacularly, from less than $\$ 10$ billion in 1991 to over $\$ 180$ billion in $2000 .^{65}$

\footnotetext{
${ }^{60}$ See sources cited supra at note

${ }^{61}$ See Vandenbergh, supra note _ at 25.

62 Vandenbergh, supra note _ at 23.

63 See Steve Kaplan and Antoinette Schoar, Private Equity Performance: Returns, Persistence and Capital Flows 2 (NBER Working Paper No. _, November, 2003).

${ }^{64}$ Kaplan and Schoar, supra note _ at 5. For more detail on the contractual rights and obligations of private equity general and limited partners, see Josh Lerner, Venture Capital and Private Equity 71-77 (2000).

${ }^{65}$ Kaplan and Schoar, supra note _ at 2. Flows into venture capital funds expanded from roughly zero in the mid-1970's to $\$ 17.2$ billion in 1998 , with the most dramatic growth occurring after 1978 , when federal pension law was amended to allow pension funds to invest in high risk assets, and with the tremendous increase in financial wealth that occurred during the bull stock market of the late 1990's. Paul A. Gompers and Josh Lerner, The Venture Capital Cycle 1, 1-10 (2002). See also Josh Lerner, Venture Capital and Private Equity 42 (2000) (noting that after the relaxation of pension fund investing guidelines in 1978, pension fund investments in private equity skyrocketed, from $\$ 64$ million in 1978 to $\$ 4.4$ billion in 1985). Private equity has also become a significant force in the United Kingdom (U.K.) where according to Peter Temple, Private Equity: Examining the New Conglomerates of European Business 1 (1999), private equity finance accounted for more than half of all "normal" (that, excluding mega-mergers) merger and acquisition activity in the U.K. in 1997.
} 
There are various kinds of private equity investments. Perhaps most famously, private equity (in the form of venture capital funds) provides capital to entrepreneurs for the development and start up of new companies. ${ }^{66}$ In its LBO (or related buy-in) form, private equity provides capital for existing managers to buy a business, group of businesses or subsidiary company from a parent company. ${ }^{67}$ Private equity may most commonly mean private independent venture capital firms, whose goal is to eventually sell or take public the firms they buy or finance at a healthy profit. But the world of private equity also includes so-called "captive" venture investments. Controlled by large corporations such as Microsoft, the goal of these funds is to pursue "strategic" (as opposed to "financial") objectives by investing in companies that will allow them to increase the value of their core business assets core business by acquiring related assets owned by smaller or startup firms. ${ }^{68}$

Financial and strategic private equity investors are likely to have quite different attitudes toward regulatory risks associated with the assets in which they invest. Consider first the traditional financial private equity firm (such as a VC firm). Traditional financial private equity investors are generally looking for the high returns that come from being willing to invest for a fixed, medium term period (that is typically ten years) in ventures of above-average risk. ${ }^{69}$ For such investors, the objective of the private equity "game" is to acquire corporate assets (either a firm or part of one), "fatten them up" into an attractive business and then sell that business for substantially more than the original purchase price. ${ }^{70}$ Regardless of whether the assets are sold to larger company in the same or related industry or taken public, the ability of financial private equity investors to exit their investments with

\footnotetext{
${ }^{66}$ See Temple, Private Equity, supra note __ at 4.is

${ }^{67}$ Temple, Private Equity, supra note _ at 4. Private equity may also be provided to an established company to finance production expansion, the development of a new company or a strategic asset acquisition. Id. ${ }^{68}$ For a formal model of strategic venture investing and the distinction between financial and strategic investing, see Thomas Hellman, A Theory of Strategic Venture Investing, 64 J. Fin. Econ. 285 (2002).

${ }^{69}$ Temple, Private Equity, supra note _ at 3.
} 
such a sale is crucial to the entire private equity process, shaping everything from how funds are raised to where they are invested. ${ }^{71}$ As Gompers and Lerner opine, because the typical private equity fund only lasts a decade, "if private equity investors cannot foresee how a company will be mature enough to take public or sell at the end of the decade, they are unlikely to invest in the firm." ${ }^{, 72}$ Indeed, in more than a few instances, private equity investors have had a potential buyer in mind before they have even bought the target firm. ${ }^{73}$ While the absolute magnitude of target rates of return on their investments have varied historically (as the rate of inflation has steadily fallen and remained low) and with the type of investment, financial private equity investors are looking for big returns, ranging from 20 to 50 per cent per year. ${ }^{74}$ Whether achieved by an early stage investment in a risky start-up company or by acquiring and turning around the management of an existing firm or division, the fundamental determinant of a private equity investment's expected internal rate of return is the expected market value of the firm at the exit time (in the case of an early stage investment, in an IPO, in the case of a turn around investment, to another firm). ${ }^{75}$

\footnotetext{
70 Temple, Private Equity, supra note _ at 3.

71 Paul A. Gompers and Joshua Lerner, The Venture Capital Cycle 205 (1999, $1^{\text {st }}$ paperback ed. 2002)

${ }^{72}$ Gompers and Lerner, Venture Capital Cycle, supra note _ at 206. See also Temple, Private Equity, supra note _ at 101 ("the private equity investor will almost certainly have thought long and hard about how and when to exit, even before the investment has been made. Assessing the chances of a profitable exit is a key aspect of deciding whether to invest in a particular situation").

73 Temple, Private Equity, supra note _ at 101.

74 According to Peter Temple, Private Equity, supra note _ at 47, target rates of return vary little between the U.S. and U.K., but range from 50\% for early stage investors to around $20-30 \%$ for conventional buyouts, buyins, and development capital; the lower the target rate of return, however, the earlier is the planned exit from the investment. One thing that accounts for the high rates of return expected by private equity investors is their use of leverage. Temple, Id. Thus as I discuss later credit providers' attitudes toward regulatory risks influence private equity investments, just as they influence any investment that is dependent at least in part on debt financing.

${ }^{75}$ See Temple, Private Equity, supra note _ at 46 (“[w] hile a trade buyer may pay more for a business than it would fetch on flotation, the likely value of the company on the stock market will be the basis of the best guess made of the ultimate value of the company on exit..."). Since future market value is itself highly uncertain, valuation is necessarily uncertain, and private equity investors have often used extremely high discount rates in discounting future returns. On this issue and for a more general discussion of alternative methods of valuing private equity investments, see Gompers and Lerner, supra note _ at 181-200.
} 
Insofar as private equity investors are making financial investments - buying a company or part of a company seeking a quick turnaround resale - they are likely to place a great deal of emphasis on the size (or certainty) of the potential resale market. In the language of the investment world introduced in this section, the general individual asset buyer of my earlier analysis is a strategic, internally financed buyer. Compared with that benchmark, financial private equity buyers are unlikely to enjoy a comparative advantage in regulatory compliance. Indeed, while they are likely to spend even more on due diligence than an internally financed strategic buyer, they are likely to be extremely risk averse with respect to regulatory risks that such an investigation may reveal. The reason is that once

they know about such risks, they also know that other potential future buyers will likely find out about such risks, and that many such buyers - financial buyers such as themselves - will not be interested in such a "dirty" asset.

From this, one cannot conclude that private equity weakens asset transactions as a driver of environmental improvement. The reason is that not all private equity investment is financial. Private equity can also be used to finance strategic investments, made to acquire assets that are then integrated into an ongoing firm's operations. Strategic private equity thereby facilitates transactions that allow for gains from regulatory comparative advantage. Inasmuch as private equity expands the set of strategic transactions that occur, its existence enhances the potential for asset transactions that lead to improvements in firm environmental performance.

\section{The Transactional Multiplier in Public Securities Markets}

A. The Transmission of Information in Public Securities Markets

Private buyers of companies and land necessarily assume a great deal of asset-specific risk. It is true that through syndication, securitization and other devices, such buyers and 
their capital providers attempt to diversify away such asset-specific risk. Even after such diversification efforts, however, they are still left with a strong incentive to both investigate the regulatory risks associated with a particular potential asset acquisition, and to operate those assets once acquired so as to efficiently manage environmental and other regulatory risk. With a lot at stake, private investors have an incentive to spend significant amounts investigating and controlling for regulatory risk.

Public shareholders present a starkly contrasting picture. Such shareholders do not have a legal right to manage or control the firms in which they invest. Their small investments are highly liquid and easy to diversify. Public shareholders cannot exercise managerial control to reduce risk, but they don't need to: they can simply assemble the market portfolio of stocks, confident that on even weakly efficient stock markets, the price of any particular security will be discounted for firm-specific risks, including regulatory risk.

Given that information acquisition is costly, a world of millions of tiny shareholders creates something of a paradox: shareholders rely upon market prices to inform their buy and sell decisions, but given perfectly informative market prices, no shareholder would have an incentive to incur positive costs of trying to discover information that is not already public and incorporated into market share prices. ${ }^{76}$ More generally, with large, sunk costs of information acquisition, the cost of becoming informed can only be worthwhile for a shareholder who is able to leverage, and arbitrage, trades in sizeable blocks of stock. ${ }^{77}$

Viewed in this light, the investment problem on public markets has a relatively simple solution. Insofar as millions of shareholders are after the same thing - to maximize

\footnotetext{
${ }^{76}$ Sanford Grossman and Joseph Stiglitz, The Impossibility of Informationally Efficient Markets, 70 Amer. Econ. Rev. 393 (1980).

77 Uninformed traders are thus those who for one reason or another, such as borrowing constraints, cannot buy the market. See James Dow and Gary Gorton, Profitable Informed Trading in a Simple General Equilibrium Model of Asset Pricing, 67 J. Econ. Theory 327 (1995).
} 
their risk-adjusted return from holding stocks and other securities - there is a market for agents who become informed and manage the portfolios of their clients so as to deliver what small investors want. This is the world of mutual funds and stock analysts. Economists have long questioned whether a mutual fund manager who "actively" manages her clients' portfolios -- by picking among individual stocks based on reports by analysts about the future prospects for their issuing companies - can generate a better risk-adjusted return than the client could achieve simply by holding the market portfolio. ${ }^{78}$ Regardless of the skepticism of financial economists, millions of people continue to invest their money in actively managed mutual funds that use information about individual companies provided by market analysts in an attempt to "beat the market." Even as the evidence mounts that analysts' recommendations are often biased and fail to make full use of available and relevant economic information, ${ }^{79}$ economists have shown that even a slight probability that mutual fund managers know what they are doing may justify people putting at least some of their money in actively managed mutual funds. ${ }^{80}$

Thus there is a large and active industry of mutual fund managers and stock market analysts, all of whom attempt to discern the likely future financial prospects of firms with publicly traded stocks and bonds. To the extent that a firm's environmental performance has an influence on its bottom line, mutual fund managers will use their knowledge of that risk in their decisions regarding how much of the firm's stock to buy or sell. And while an ordinary person's decision to buy or sell a few shares has no impact on share price,

\footnotetext{
${ }^{78}$ Beginning with Michael C. Jensen, The Performance of Mutual Funds in the Period 1945-1964, 23 J. Finance 389 (1968), decades of empirical studies have found that actively managed mutual funds do not on average outperform the market.

${ }^{79}$ See. e.g., Narasimhan Jegadeesh, Joonghuk Kim, Susan D. Krische and Charles M.C. Lee, Analyzing the Analysts: When do Recommendations Add Value?, 59 J. Finance 1083 (2004).

${ }^{80}$ For a model showing that even a slight probability of mutual fund managerial stock-picking skill may justify investors in holding a positive fraction of their portfolios in actively managed funds, see Klaas P. Baks, Andrew
} 
institutional trading decisions do affect the market price of shares both in the short and long term. $^{81}$ Hence when mutual fund managers and other informed traders learn about a previously unknown regulatory risk carried by a particular firm and sell the firm's stock in response, its share price should fall. Indeed, as the information becomes public, the firm's stock price should fall by precisely the expected regulatory burden (as above, either the expected fine $p F$ or the compliance cost $c$ ).

If this is the extent of the price effect in public markets, however, then those markets have a neutral effect relative to regulatory enforcement. In the sense introduced earlier, public equity markets would not enhance incentives for firm environmental performance, but merely mirror the incentive that a fully informed firm will have already perceived. Indeed, it might seem that if anything, public securities markets create a perverse incentive for firms to take steps to conceal or remain ignorant of their regulatory costs and liabilities from the market so as to avoid adverse stock price movements.

B. Beyond Neutrality: The Market Multiplier in Public Securities Markets This possibility is unlikely. The same basic incentive to acquire and transmit information is at work in public securities markets as in private asset markets. While that incentive plays out differently in public securities markets, it nonetheless enhances the firm's incentive for regulatory compliance beyond that created by the threat of regulatory and legal enforcement.

1) Asymmetric Information and Market-Enhanced Incentives for Acquiring Information about and Controlling Environmental Regulatory Risk

Metrick and Jessica Wachter, Should Investors Avoid All Actively Managed Mutual Funds? A Study in Bayesian Performance Evaluation, 56 J. Finance 45 (2001).

${ }^{81}$ Louis K.C. Chan and Josef Lakonishok, Institutional Trades and Intraday Stock Price Behavior, 33 J. Fin. Econ. 173 (1993) [and recent J Fin article on aggregate effect]. 
In this regard, the most important difference between public securities markets and private asset markets is that mutual fund managers and stock analysts have much weaker incentives to become informed about a firm's regulatory exposures than does a private buyer of the firm (or some of its assets). Mutual funds hold shares in dozens or even hundreds of different firms, and by remaining sufficiently diversified (avoiding too large holdings in particular firms), most mutual funds can retain substantial liquidity, in the sense that they can buy, sell and alter their portfolios without having major effects on stock prices. ${ }^{82}$ Stock analysts tend to cover entire industry sectors, and to rank firms as potential investments relative to other firms in the same industry. Firm-specific risks such as a firm's potential regulatory exposures thus are likely to be diversified away by fund managers - so that they are indifferent to them - unless the risks are so large, and so bad relative to other firms in the same business that analysts dissuade managers from holding a firm's stock at all. Analysts reports and fund managers' knowledge of firm-specific regulatory risks rarely if ever would approach the level of knowledge that a private buyer of the firm or a portion thereof would acquire through due diligence.

For precisely this reason, however, managers should rationally fear that if and when a regulatory problem affecting their firm becomes public knowledge, fund managers and analysts will likely have their expectations about future firm financial performance upset, and to collectively sell so many shares that the firm's stock price falls. It is, moreover, likely to fall by significantly more than the actual liability or cost associated with the particular regulatory event. The reason has to do with once again with the distinction between known, priced risks and unknown risks that I adduced earlier in my discussion of advantageous selection possibilities in asset markets. When a previous unpriced, unknown risk is

\footnotetext{
82 The important exceptions are funds, such as CALPERS, that are so large that even when they hold the
} 
discovered by market participants, they will rationally increase their subjective probability that other unknown risks also exist. Economists have not yet developed canonical formal models of how such subjective beliefs regarding lack of knowledge (or more precisely, degree of unawareness) are formed and adjusted. ${ }^{83}$ Whatever the precise magnitude of the adjustment in beliefs, however, when analysts and mutual fund managers are surprised by a previously unknown regulatory risk affecting its firm, they are likely to take that risk as a signal that there are likely others affecting the same firm that are still unknown to them, ${ }^{84}$ and to push the firm's stock price down by significantly more than the magnitude of the actual liability or regulatory cost entailed by the surprise event. ${ }^{85}$

2) Incentives for Voluntary Disclosure of Bad Environmental News: The Credibility Problem

Thus provided that firm managers know that mutual fund managers and analysts are far from fully informed about any particular firm's regulatory risks and will overreact to unexpected bad news when such a risk is realized, firm managers' incentives to lessen or eliminate such risks will be greater than if there were no such market reaction to worry about. Of course, this is true only insofar as managers care about short-term stock price movements. Regardless of whether or not one thinks it is a good thing, there currently is consensus that stock option and equity - based managerial compensation schemes have

market portfolio, they still have such large holdings that their actions affect market price.

83 [cite a couple of recent things on formalizing unawareness].

84 On this point, see Paul Lanoie, Benoit Laplante and Maite Roy, Can Capital Markets Create Incentives for Pollution Control?, 26 Ecological Econ. 31 (1998).

${ }^{85}$ For evidence that the stock market imposes precisely such a penalty magnification upon manufacturers of recalled drugs and cars, see Greg Jarrell and Sam Peltzman, The Impact of Product Recalls on the Wealth of Sellers, 93 J. Pol. Econ. 512 (1985); for a similar study involving the effect of press reports of allegations of corporate fraud, finding that the stock price falls by an order of magnitude more than the expected penalties and criminal fines, see Jonathon M. Karpoff and John R. Lott, the Reputational Penalty Firms Bear from Committing Criminal Fraud, 36 J. Law \& Econ. 757 (1993). But see Cindy R. Alexander, On the Nature of the Reputational Penalty for Corporate Fraud: Evidence, 42 J. Law \& Econ. 489 (1999) (finding significant market price effects only in cases involving contractual, or "related party" fraud, where it is reasonable to expect that market price drop measures expected reputational, extralegal sanctions.) 
made corporate managers more sensitive than ever before to short-term stock price performance.

Ideal managers, however, worry about long-term firm value maximization, rather than short-term value. From the point of view of market participants with long-term value maximization as a goal, the ideal manager is one who is knowledgeable about the firm's longterm prospects, both positive and negative. When it comes to regulatory liabilities, what such investors want to see is a long-term managerial strategy to minimize those risks and prevent them from threatening the firm's continued growth in earnings. Managers cannot have effective long-term strategies for dealing with regulatory exposure unless they are knowledgeable about the extent of their firm's exposure. Thus just as a private asset seller may have an incentive to disclose enough to a potential buyer to show that buyer that she is indeed aware of the potential regulatory liabilities carried by a particular asset, so too may managers of public companies have an incentive to demonstrate their knowledge of regulatory risks to market analysts and mutual fund managers.

This is surely true of general knowledge, but what about the disclosure of specific regulatory risks and liabilities of which managers have knowledge but analysts and mutual fund managers do not? The answer to this question turns on general managerial incentives for disclosure of firm-specific information that is known to be of material significance to market participants. Space does not permit me to summarize adequately here the vast theoretical and empirical literature in economics and accounting on the disclosure issue. ${ }^{86}$ The most important points from that literature for present purposes may indeed be its relative inapplicability to the problem of incentives to disclose bad environmental news.

\footnotetext{
${ }^{86}$ For an overview of the theoretical models, see Robert E. Verrechia, Essays on Disclosure (June 2001); [add survey of empirical work]
} 
The first thing is to dispense with the notion that because firms with good environmental news will have an incentive to reveal it, firms who don't voluntarily reveal such good news will be revealed to have bad news. ${ }^{87}$ This result holds only when the information revealed to market participants is perfectly verifiable, and when every firm has the same sort of information that could be revealed. The paradigm generating the theoretical result is product quality. Environmental regulatory exposure is not like product quality. Environmental regulatory exposure is not perfectly verifiable; moreover, it is not an on-off, observable one-dimensional attribute that every firm "has," so that the inferences can rationally be drawn from a particular firm's failure to voluntarily reveal. Indeed, in a very real, and very important sense, good news about environmental regulatory exposure is incapable of being simply revealed in the same way as something like product quality. If the good news is in the form of an excellent history of compliance with existing regulations, and investing in pollution control technologies, then market participants may be skeptical that the investments and compliance record will continue, that the typically large costs of properly maintaining the abatement technology will continue to be made in the future. Moreover, the regulatory environment may change, so that what was once "good" performance is no longer up to regulatory standards.

These differences between financial and environmental performance data are ignored by the relatively small body of work that attempts to apply the financial theory of voluntary (that is, discretionary) disclosure to generate predictions about when firms will voluntarily disclose environmental risks. ${ }^{88}$ That literature relies upon work in theoretical accounting

\footnotetext{
87 This is known as the "unraveling result" and was modeled first by Sanford Grossman, The Informational Role of Warranties and Private Disclosure about Product Quality, 24 J. Law \& Econ. 461 (1981); Paul Milgrom, Good News and Bad News: Representation Theorems and Applications, 12 Bell J. Econ. 380 (1981).

88 Yue Li, Gordon D. Richardson, and Daniel B. Thornton, Corporate Disclosure of Environmental Liability Information: Theory and Evidence, 14 Contemp. Acct. Res. _ (1997); Ahmed Riahi-Belkaoui, The Extent of
} 
which explains why the unraveling result is not in fact observed with respect to financial data; why, that is, voluntary disclosure does not cause all firms to disclose. On these models, when firms incur "proprietary costs" to disclose (in that they have information about future demand, say, the disclosure of which would effect product market competition ${ }^{89}$ ) or when investors do not know whether or not managers even have any information to disclose, ${ }^{90}$ then generally only firms with very good information will voluntarily disclose it, so that voluntary disclosure conveys some but still imperfect information to the market. These models, however, cannot be directly applied to analyze incentives for voluntary disclosure of potential environmental regulatory risks. Environmental regulation is generally sector-based, and if one firm in an industry foresees environmental regulatory problems, so too will others in its industry. Disclosure generally has no effect on product market competition, so that the proprietary cost models are not helpful.

Models that hinge upon the market's uncertainty about whether managers have private information may seem to have greater potential applicability to the problem of environmental disclosure. However, as argued above, at least in industries where environmental risk management is important to firms' bottom lines, their managers should have a strong incentive to try to persuade the market that they are indeed will informed about such risks. Thus managers have an incentive to eliminate the kind of asymmetric information about the state of their information regarding environmental regulatory risks that drive the partial disclosure financial models. So again it is not clear whether those models really apply to the problem of environmental disclosure. Moreover, the most

Environmental Disclosures: Effects of Regulatory Costs and Level of Exposure to Environmental Risk, 1 Int.J. Envl. Tech. \& Manage. 75 (2001).

${ }^{89}$ Robert Verrechia, Discertionary Disclosure, 5 J. Acct. \& Econ. 179 (1983).

${ }^{90}$ R.A. Dye, Disclosure of Nonproprietary Information, 23 J. Acct. Res. 123 (1985). 
credible kinds of information about environmental risks tend to be bad news, news about impending liability or regulatory compliance costs. Such information generally becomes public knowledge quite quickly anyway, so it is hard to see how there could be much incentive for early, voluntary disclosure, unless it is disclosure designed to "spin" the bad news in the hopes of lessening its negative market impact. ${ }^{91}$

Still, there is a body of work in finance which shows that asymmetric information increases the firm's external cost of capital, ${ }^{92}$ and if a firm could somehow credibly commit to rapid and full disclosure of environmental risk information, then it could lower its capital costs by assuring investors that they needn't worry about information asymmetry. ${ }^{93}$ The problem is that especially when it comes to bad news about future environmental risks, managers who succeed in persuading the market that they are very well informed will for that very reason find it difficult if not impossible to make such a credible commitment. If investors really have worse information than managers, they may never find out that managers could have but did not disclose negative information.

There are two means of creating a credible commitment to voluntary disclosure of negative news regarding environmental regulatory exposure. The first is a risk that an outsider to the firm - such as a public regulator, or private environmental group - will reveal and disclose bad news if managers do not do so first. ${ }^{94}$ The second is through third party certification - again either by a public agency, or a private environmental group - that the firm's voluntary disclosures have been complete and are accurate. This second avenue to

\footnotetext{
${ }^{91}$ In critiquing Li et. al., supra note _ _, John S. Hughes, Discussion of 'Corporate Disclosure of Environmental Liability Information: Theory and Evidence,” 14 Contemp. Acct. Res. 475 (1997) makes a similar point. 92 [add cites]

${ }^{93}$ For evidence on how uncertain Superfund liability raised the capital costs for a sample of chemical companies, see Steven Garber and James K. Hammitt, Risk Premiums for Environmental Liability: Does Superfund Increase the Cost of Capital?, 36 J. Env'l Econ. \& Manage. 267 (1998).
} 
restore credibility, however, hinges upon the credibility of the third party certification.

Given that it is the firm that is in possession of the information, the firm can control third party certifiers' access to evidence about the firm's environmental risk exposure. Hence the firm can hide at least some negative information from third party certifiers. Moreover, as is all too apparent in the post-Enron world, there is an obvious incentive for third party auditors to collude with their clients and keep negative information that they have discovered from the public.

Now it is true, as always, that if third party auditors suffer reputational harm and lost profits when and if they are discovered to have colluded with clients, then those reputational sanctions may, if sufficiently large, make them honest certifiers of firm environmental risk. The problem is that the only way that third party auditors can suffer such reputational sanctions is if somebody finds out and reports they have colluded with their clients. This information can be generated in one of two ways. Regulators could find out about collusion. But the only way that regulators can catch auditor collusion is if regulators go through and re-audit the firm's environmental regulatory exposure claims. But if regulators are auditing the private auditors, and then potentially enforcing against both the auditors and the firm, then the question is whether the use of private auditors has actually generated cost savings or instead actually increased the total cost to the firm (and society) of credible disclosure.

The second avenue to information revelation about auditor collusion is market competition. Competition for business among third party certifiers could conceivably create an incentive for such auditors to check up on one another, and to reveal instances of collusion to the market in the hopes of stealing clients from auditing firms revealed as

\footnotetext{
94 I have borrowed this argument from Allen Farrell, The Case for Mandatory Disclosure in Securities Regulation Around the World 39 (Harvard Law School Law and Economics Discussion Paper No. 492, September, 2004).
} 
colluders. Such a "tattle tale" strategy, however, is unlikely to be profit maximizing for an auditor. As to be shown in a not-yet-included appendix, primarily because 1) auditors themselves have an incentive to spread false information about collusion between their competitors and their competitors' clients, and 2) some false certifications are honest mistakes in that they occur because auditors have themselves been misled by their client firms (given incomplete or misleading data upon which to base their audit), the market will probably discount tattle tale stories by a sufficient amount that a strategy of informing on others is unlikely to be superior to simply minding one's own business.

\section{3) Summary}

The previous analysis shows that it is the very fact that market participants tend to be poorly informed regarding firm-specific environmental regulatory risk that causes relatively significant market reaction to the revelation of unexpected regulatory risk. The desire to avoid such market reaction enhances managerial incentives to manage environmental risk. When the risk of revelation itself can be controlled, managers can have a perverse incentive to take steps not to lower their firms' actual regulatory exposure, but rather to hide the extent of their noncompliance from the market. However, certainly for firms with relatively high visibility, who face a significant probability that negative information will be revealed anyway by regulatory or third party enforcement action, the predominant effect of the asymmetrically informed public securities market is to enhance incentives to take steps to actually lower the firm's environmental risk.

As for the potential for voluntary disclosure of bad environmental news, my analysis implies that while there may be a kind of advantageous selection at work on public markets, its potential is much more limited that on private asset markets. On public markets, it is much more likely that external providers of capital will not find out about negative 
regulatory exposures via their own investigation. For this reason, even though public firm managers have an incentive for information acquisition, and generally wish to avoid surprising the market with unanticipated bad news, they will generally be unable to credibly commit to disclosing such bad news voluntarily unless there is a significant risk that regulators or will eventually compel them to reveal the information publicly.

C. The Evidence

1) The Effect of Disclosure of Negative Information on the Stock Market and Firm Behavior

Perhaps the most well known evidence that the stock market reacts significantly to the disclosure of negative environmental performance information and that this reaction affects managerial behavior comes from studies of the effect of the release of information on firm emissions included in the Toxic Release Inventory (TRI) that is required annually under the federal Emergency Planning and Community Right to Know Act (EPCRA). Both Hamilton $^{95}$ and Khanna found that firms disclosing information about their toxic releases suffered statistically significant losses in stock market value immediately after the disclosure. Likewise, both Khanna and Konar and Cohen ${ }^{96}$ found that firms with the biggest emissions and stock market losses had the biggest reported improvement (decline) in emissions.

While there are problems with using declines in reported emissions as proof of a change in actual corporate behavior, ${ }^{97}$ studies of stock market reaction to disclosures about firm environmental performance more generally confirm the predictions of my analysis. By

\footnotetext{
${ }^{95}$ James T. Hamilton, "Pollution as News': Media and Stock Market Reactions to the Toxic Releases Data, $28 \mathrm{~J}$. Envl. Econ. \& Manage. 98 (1995).

96 S. Konar and Mark Cohen, Information as Regulation: The Effect of the Community Right to Know Laws on Toxic Emissions, 32 J. Envl. Econ. \& Manage. 109 (1997). For a useful discussion of this and related work, see Tom Tietenberg, Disclosure Strategies for Pollution Control, 11 Envl. \& Res. Econ.587 (1998).

${ }^{97}$ Some environmental groups have justifiably argued that it is possible for firms to reduce their reported emissions simply by reclassifying some wastes as being part of, rather than a waste product from, the
} 
2003, there were already well over 100 studies of how a firm's environmental performance affects its stock market performance. ${ }^{98}$ As very usefully summarized in a recent article by Wagner and Schaltegger, ${ }^{99}$ these studies fall into three distinct groups, based upon the methodology employed. The first and largest group consists of event studies, some of the more notable of which are summarized in Table 1 below.

The event studies confirm the most important predictions of my analysis above. As Table 1 shows, the empirical work to date suggests three general stock market phenomena. First, and most importantly for present purposes, there is a consistent finding that bad environmental news causes firms to suffer negative stock market price moves. No studies of which I am aware have tried to compare the extent of a firm's negative abnormal return with its actual expected regulatory or civil liability or expected cost of getting back into compliance. Still, it seems fairly clear that negative abnormal returns on the order of 10 to $15 \%$ would likely far exceed firms' expected penalty or compliance cost. Thus as my analysis predicts, the market reacts to the revelation of bad news with a strong multiplier effect.

production process, thus removing them from the TRI. For examples of these so-called "phantom" emissions reductions, see [finish note]

98 This is an estimate inferred by extrapolating from the bibliography of 95 such studies compiled by Donald Cram and Dinah Koehler in March, 2000. This bibliography is available at

http://www/mit.edu/environmental/envir-fin-literature.html.

99 The Relationship between the Environmental and Economic Performance of Firms, 34 Green Management Intl. 95 (2001). 
Table 1

Some Event Studies of Market Reaction to

Firm-Specific Environmental Events

\begin{tabular}{|c|c|c|c|}
\hline Authors and Date & Type of Study & $\begin{array}{l}\text { Environmental } \\
\text { Performance Measure }\end{array}$ & Findings \\
\hline $\begin{array}{l}\text { Lanoie, Laplante and Roy, } \\
1998^{100}\end{array}$ & $\begin{array}{l}19 \text { Canadian firms, } \\
\text { Vancouver stock mrkt. }\end{array}$ & $\begin{array}{l}\text { Classification by British } \\
\text { Columbia Environment } \\
\text { Ministry as either "out of } \\
\text { compliance" or "of } \\
\text { concern" }\end{array}$ & $\begin{array}{l}\text { No statistically signif. } \\
\text { Abnormal returns in either } \\
\text { category }\end{array}$ \\
\hline Hamilton, $1995^{101}$ & $\begin{array}{l}436 \text { companies with }+5 \text { day } \\
\text { window }\end{array}$ & $\begin{array}{l}\text { Chemical and pathway } \\
\text { specific publicly available } \\
\text { data on } 1989 \text { TRI toxic } \\
\text { releases by facility }\end{array}$ & $\begin{array}{l}\text { Statis. signif. Abnormal } \\
\text { returns between }-.2 \text { and } \\
-.3 \%\end{array}$ \\
\hline $\begin{array}{l}\text { Dasgupta and Laplante, } \\
2001102\end{array}$ & $\begin{array}{l}10 \text { day window of } 48 \\
\text { publicly traded firms in } \\
\text { Argentina, Chile, Mexico } \\
\text { and the Philippines }\end{array}$ & $\begin{array}{l}7354 \text { positive and negative } \\
\text { environmental news stories } \\
\text { appearing in selected } \\
\text { newspapers during } 1990 \text { - } \\
1994\end{array}$ & $\begin{array}{l}\text { Stories of government or } \\
\text { citizen complaints generate } \\
4-15 \% \text { decline in firm } \\
\text { market value (stat. signif. At } \\
.10 \text { level); only positive } \\
\text { government recognition w. } \\
\text { statis. Signif. Positive effect }\end{array}$ \\
\hline Gupta and Goldar, $2003^{103}$ & $\begin{array}{l}15 \text { day window of } 78 \text { firms } \\
\text { in pulp and paper, } \\
\text { automobile manufacturing } \\
\text { and chlor alkali industries }\end{array}$ & $\begin{array}{l}\text { Publication of initial } \\
\text { comparative, plant specific } \\
\text { environmental rating by the } \\
\text { leading Indian } \\
\text { environmental NGO }\end{array}$ & $\begin{array}{l}\text { Statistically significant (SS) - } \\
.27 \text { average abnormal return } \\
\text { for pulp and paper; no } \\
\text { signif. Result in chlo alkali; } \\
\text { autos SS. } 13 \text { ab. Ret. }\end{array}$ \\
\hline White, 1996104 & $\begin{array}{l}6 \text { month event window; } \\
\text { Exxon, Alyeska consortium } \\
\text { firms, and Exxon } \\
\text { competitors }\end{array}$ & Exxon Valdez oil spill & $\begin{array}{l}\text { SS Immediate, cumulative } \\
\text { and lasting negative } \\
\text { abnormal returns for } \\
\text { Exxon; no effect for others }\end{array}$ \\
\hline Dasgupta et. al., 2004105 & $\begin{array}{l}7 \text { day event window, } 87 \\
\text { firms, negative disclosures }\end{array}$ & $\begin{array}{l}\text { Gov't notices of violation } \\
\text { picked up by news media }\end{array}$ & $\begin{array}{l}52 \text { of } 87 \text { suffered SS } \\
\text { negative abnormal returns } \\
\text { avg'ing } 9.7 \%\end{array}$ \\
\hline $\begin{array}{l}\text { Klassen and McLaughlin, } \\
1996^{106}\end{array}$ & $\begin{array}{l}3 \text { day window, } 96 \text { firms (16 } \\
\text { for negative) }\end{array}$ & $\begin{array}{l}\text { Positive events (receipt of } \\
3 \mathrm{~d} \text { party envl award) and } \\
\text { negative reg. events }\end{array}$ & $\begin{array}{l}\text { SS } 63 \% \text { abnormal return for } \\
\text { positive news; }-.82 \text { for } \\
\text { negative events }\end{array}$ \\
\hline
\end{tabular}

100 Paul Lanoie, Benoit Laplante and Maite Roy, Can Capital Markets Create Incentives for Pollution Control, 26 Ecological Econ. 31 (1998).

${ }^{101}$ James T. Hamilton, Pollution as News: Media and Stock Market Reaction to the Toxic Release Inventory Data, 28 J. Envl. Econ. \& Manage. 98 (1995).

102 Susmita Dasgupta and Benoit Laplante, Pollution and Capital Markets in Developing Countries, 42 J. Envl. Manage. 310 (2001).

103 Shreekant Gupta and Bishwanath Goldar, Do Stock Markets Penalise Environment-Unfriendly Behavior? Evidence from India, Dehli School of Economics, Center for Development Economics, Working Paper No. 116 (March, 2003).

104 Mark A. White, Investor Response to the Exxon Valdez Oil Spill (University of Virginia, 1996), available at http://etext.lib.virginia.edu/etcbin/br...SI/archive/images\&data=/lv6/OSI/archive.

105 Susmita Dasgupta, Jong Ho Hong, Benoit Laplante and Nlaundu Mamingi, Dislcosure of Environmental Violations and the Stock Market in the Republic of Korea, World Bank Policy Research Working Paper 3344 (June 2004).

106 Robert D. Klassen and Curtis P. McLaughlin, The Impact of Environmental Performance on Firm

Performance, 42 Manage. Sci. 1199 (1996). 
The event studies also suggest that the size of the market multiplier increases with the level of investors' uncertainty regarding the full extent of a firm's potential environmental regulatory exposure. A look back at Table 1 shows that the disclosure of bad news induces very large declines in stock prices only in developing country stock markets. A plausible explanation for this phenomenon is that market participants in developing country stock markets operate with worse information than do their developed country counterparts, and therefore are surprised more often, and more significantly, by the revelation of bad news.

Finally, the studies tend to show a relatively weak stock market reaction to good news, such as the firm's receipt of an award from an environmental group or some other award, although government awards for superior environmental performance do seem to have some small positive effect. In the next part of this article, I explain why rational investors should indeed be expected to be relatively indifferent to good news of this form.

In measuring the impact of both positive and negative environmental news on share prices, event studies suffer from several weaknesses inherent in their methodology. In brief, that methodology involves: 1) identification of publicly known events and a time period over which to study the reaction of stock prices to those events (the event window), as well as a sample firms; 2) prediction of "normal" returns for those firms over this period in the absence of the event; 3) calculation of "abnormal" return during the event window, where the abnormal return equals the difference between the actual and predicted stock market return; and, 4) testing whether the abnormal return is statistically different than $0 .{ }^{107}$ Event studies proceed upon the assumption that capital markets are efficient, at least in the "semi-

\footnotetext{
${ }^{107}$ For a more detailed discussion, see A. C. MacKinlay, Event Studies in Economics and Finance, 35 J. Econ. Lit. 13 (1997). Normal returns are those that are predicted by a standard model of securities returns, such as the market model or capital asset pricing model.
} 
strong" sense that markets eventually incorporate all publicly available information into stock prices. ${ }^{108}$ This means that it takes the market a while to assimilate new information, even information that is easy to interpret in bottom line terms. Such ease of interpretation is hardly true of either positive or environmental news, which generally does not come with a precise dollar figure attached to it. The problem, however, is that the longer is the period after the event over which event studies measure stock prices -- the event "window" - the greater is the risk that something other than the event (some unobserved "confounding" factor) has caused any observed abnormal share price movement. If markets are efficient in the semi-strong form, it will take them a while - weeks, even months, for complicated events - to figure out how the event will affect the firm's revenues, costs and profits. But event studies cannot extend their windows this far without making confounding bias a virtual certainty.

Due to these limitations on the event study methodology, investigators have taken a variety of approaches to measuring the relationship between stock market value and firm environmental performance. They have broadened their measures of firm environmental performance to consider such measures as publicly disclosed toxic emissions (or changes therein), internal firm environmental policies (does the firm, for instance, have an environmental management system in place?) and firm environmental ratings by external ratings agencies. They have also broadened their measure of firm economic performance to consider directly the firm's capital value, or return on investment. ${ }^{109}$

These studies too generally confirm the predictions of my analysis. Since the studies employ widely varying measures of both environmental and economic performance for widely varying samples of firms, their contrasting findings cannot be directly compared.

\footnotetext{
108 [add cite to recent literature on market efficiency and semi-strong efficiency]
} 
Still, taken as a whole, these regularly find a market penalty for bad environmental news (or bad environmental performance), and at least a positive correlation between good environmental performance and good economic performance. ${ }^{110}$

2) Evidence of Voluntary Disclosure: Confirming the Model

Compared with studies of the stock market's reaction to the disclosure of environmental news, there has been much less empirical work exploring the magnitude and determinants of voluntary environmental disclosure by firms. Most of the work in the accounting literature, for example, has been focused primarily not on incentives for voluntary disclosure, but on whether various Securities and Exchange Commission (SSEC) and Financial Accounting Standards Board (FASB) rules and guidance regarding the disclosure of contingent (i.e., unrealized) environmental liabilities have led to increased disclosure. ${ }^{111}$ The general finding in this literature is that SEC rules matter, and do lead to increased disclosure of such liabilities. ${ }^{112}$ While the influence of specific regulatory rules remains somewhat unclear, ${ }^{113}$ more general empirical work comparing levels of disclosure

${ }^{109}$ For a good summary of such studies, see Wagner and Schaltegger, supra note _ at 104 .

110 One of the best such studies is Shameek Konar and Mark A. Cohen, Does the Market Value Environmental Performance?, 83 Rev. Econ. \& Stat. 281 (2001). For the average firm in the Konar and Cohen sample, a 10\% reduction in toxic emissions would have resulted in a $\$ 34$ million increase in firm value, or approximately .7\% of the replacement value of firm assets. Importantly, although intangible asset losses due to poor environmental performance exhibited tremendous variation across industries (ranging from 1\% in the transportation equipment industry to $31 \%$ in the chemical industry), such effects were present even after Konar and Cohen controlled for industry fixed effects. They did not, however, include a firm fixed effects variable, leaving the possibility that a firm's toxic emissions might be proxying for unobserved firm-specific attributes. Their conclusion that environmental litigation is economically insignificant in most industries, is rather too broadly put. What they have actually found is that in a particular year, 1989, the number of environmental lawsuits pending against a firm did not significantly effect firm value for the average firm, while for two firms with a very large number of environmental lawsuits, these lawsuits had a catastrophic effect on firm value.

112 See, for example, Mary E. Barth, Maureen F. McNichols and G. Peter Wilson, Factors Influencing Firms' Disclosures about Environmental Liabilities, 2 Rev. Acct. Stud. 35 (1997)(finding that firms increased environmental disclosures in response to increased SEC monitoring). E. Stanny, Effect of Regulation Changes in Disclosure of Reserved Amounts for Environmental Liability, 3 J. Fin. Statement Analysis 34 (1998).

${ }^{113}$ For evidence that firms did not increase their disclosures in response to SEC Staff Accounting Bulletin 92 (put out in 1993), se Carol Cox Leary, Factors Influencing the Level of Environmental Liability Disclosure in 10K Reports (2001, mimeo, George Mason University). 
across countries also shows that levels of disclosure are much higher in countries where regulators and/or legislation requires disclosure (or is threatening to do so soon), than in countries, such as the United States, with relatively little required disclosure. ${ }^{114}$

Inasmuch as it has consistently found very little voluntary disclosure of negative environmental regulatory information, ${ }^{115}$ this literature confirms my general prediction that market forces alone do not encourage such disclosure. The literature also confirms my central conjecture: that the firms which disclose the most are those that are large, and in industries with high regulatory exposure, and hence a high probability their environmental regulatory problems will be revealed via regulatory or citizen enforcement. ${ }^{116}$

114 See Ans Kolk, Trends in Sustainability Reporting by the Fortune Global 500, 12 Bus. Strat. \& Env. 279 (2003) (finding an increase in SR disclosures between 1998 and 2001 in countries where more disclosure is being required, or is threatened, but a decrease in such disclosures among the U.S. companies in the sample); Rob Gray, Reza Kouhy and Simon Lavers, Corporate Social and Environmental Reporting: A Review of the Literature and a Longitudinal Study of UK Disclosure, 8 Acct., Audit. \& Accountability J. 47 (1995)(finding an increase in disclosure, most of which was required, but only cursory disclosure of non-required environmental disclosure).

115 This is demonstrated by some of the early studies, which predated SEC involvement in requiring disclosure, such as R. Ingram and K. Frazier, Environmental Performance and Corporate Disclosures, 18 J. Acct. Res. 614 (1980); M. Freedman and C. Wasley, the Association between Environmental Performance and Environmental Disclosure in Annual Reports and 10K's, Adv. Public Interest Accting. 183 (1990); G.,O. Gamble, K. Hsu and R. Radke, Environmental Disclosures in Annual Reports and 10K's: An Examination, 9 Accting. Horizons 34 (1995). It has also been the consistent finding of government studies, such as the 1998 EPA Study of Environmental Compliance Reporting [get cite] and the 2002 SEC Survey of Fortune 500 Companies [get cite] and the summer, 2004 GAO report [get cite]. For similar findings from Australia (summarized in the latter article as indicating that it is "unlikely that voluntary environmental reporting creates an environment of adequate and appropriate disclosure for poor environmental performers"), see C. Deegan and M. Rankin, Do Australian Companies Report Environmental News Objectively? An Analysis of Environmental Disclosures by Firms Prosecuted Successfully by the Environmental Protection Authority, 9 Acct., Audit. \& Accountability J. 50 (1996): Jason Mitchell, Majella Percy and Bridget McKinlay, Voluntary Environmental Reporting Practices: A Further Study of "Poor" Environmental Performers (University of Michigan Business School, July 2004). 116 Dennis M. Patten, The Relation between Environmental Performance and Environmental Disclosure: A Research Note, 27 Acct. Org. \& Soc. 763 (2002), finds that firms with higher levels of TRI emissions also disclose more, which he takes as evidence that a company's level of exposure to regulatory and political enforcement increases its level of disclosure. Consistently, S. Hughes, A. Anderson and S. Golden, Corporate Environmental Disclosures: Are they Useful in Determining Environmental Performance?, 20 J. Acct. Pub. Pol. 217 (2001) found significant differences in the environmental disclosures of good, mixed and poor environmental performers in annual report notes and management discussion and analysis, with poor performers providing the greatest amount of disclosure. While disagreeing over precisely what TRI releases measure, a recent study that controls for the endogeneity between environmental performance and environmental disclosure, Sulaiman A. Al-Tuwaijri, Theodore E. Christensen and K.E. Hughes, II, The Relations Among Environmental Disclosure, Environmental Performance, and Economic Performance: A Simultaneous Equations Approach, 29 Acct. Org. \& Soc. 447 (2004) similarly finds that public visibility and environmental exposure are significantly positively related to the level of a firm's environmental disclosures. 


\section{Extended Preferences: Socially Responsible Consumers and Investors}

Some consumers and investors many have much broader preferences than are assumed by what I have called the neoclassical or self-interested model of behavior. Rather than caring just about product characteristics or the financial return from holding a firm's stock, consumers and investors may care about the firm's social, environmental and labor practices, about how the firm has produced its product and achieved its financial results. ${ }^{117}$ Such consumers and investors may be willing to pay more for the product or stock of firms with good social and environmental performance, thus providing a positive market reward for such performance. That is, just as market transactions involving neoclassical investors may heighten the effect of bad firm environmental performance, so too may market transactions involving SR consumers and investors offer market carrots - in the form primarily of price premia - that reward firms for especially good market social and environmental performance.

In this part of the article, I argue that the ability of such SR consumers and investors to significantly change firm incentives depends not only upon the number of such SR actors, but also, and crucially, upon the ability of firms to credibly commit to "socially responsible" performance. I consider the relative roles of potential legal liability, versus market intermediaries -- largely, at least to date, various non-profit non-governmental organizations (ngo's) - in enabling firms to make such credible commitments. I conclude that as a general

For a similar finding, but using ordinary least squares, see Leary, supra note _. See also S. Cowen, L. Errreri and L. Parker, The Impact of Corporate Characteristics on Social Responsibility Disclosure: A Typology and Frequency-Based Analysis, 12 Acct., Org. \& Soc. 111 (1987); Dennis M. Patten, Exposure, Legitimacy and Social Disclosure, 10 J. Acct. \& Pub. Pol. 297 (1991). 
matter, the likely market return to credible commitments to corporate SR is insufficient to motivate firms to make such commitments in the absence of a regulatory requirement.

It has become common to take it for granted that consumers and investors just simply "have" SR preferences will enact those preferences in their consumption and investment decisions. ${ }^{118}$ I believe that this inference - from SR preferences to SR actions is unwarranted, and so I begin by taking a look at the economic rationality of socially responsible investing and consumption activities.

A. Should SR Consumers and Investors Make SR Consumption and Investment Decisions? Direct versus Indirect Expression of SR Preferences

My project here is not to explore how or why some consumers and investors might have SR preferences. Still, the precise specification of SR preferences is important in developing a positive theory of the behavior of such SR consumers and investors. Insofar as SR consumers and investors get utility or disutility from the way companies do business more specifically the environmental, social or labor harm that they cause - there is no reason to think that their concern should be limited to companies whose products they buy or whose stocks they hold. That is, SR investors and consumers are SR people who decide to express their preferences through their product and stock purchase decisions. Now it may be that the only reason why SR consumers and investors avoid buying products or stock from "bad" companies is because they would feel even worse about a bad company's environmental record if they owned its product or stock than they do anyway, since then they would have contributed to such a "bad" company's market success. But it is also

${ }^{117}$ For a wide ranging, but non-economic analysis of the various legal implications of SR consumer preferences, see Douglas Kaysar, Preferences for Process, supra note _.

${ }^{118}$ An important exception is Kysar, Preferences for Processes, supra note _, who at expends considerable attention, 118 Harv. L. Rev. 525, 582-640, discussing possible explanations for SR consumer preferences, but these do not include the very basic economic calculus that I offer below. 
possible that SR consumers and investors avoid buying the products and stock of bad companies, while favoring those of good companies, because they want to penalize the bad companies with a decline in sales and stock market valuation and reward the good companies with increased sales and profit growth and increasing stock market value.

A rational individual (as opposed to institutional) consumer or investor, however, must realize that (aside from very special cases) ${ }^{119}$ his or her decision to buy or not buy a particular company's product or stock will have no impact on that company's bottom line. The quantity of goods or securities purchased by a typical individual is so small that it will go completely unnoticed by a typical large corporation. For this reason, SR consumers and investors may be better off economizing in their market purchase decisions and then investing the money they save buying the products and make buying the stocks of bad SR companies in other attempts to influence the behavior of such companies. Rather than spending $\$ 1000$ per year more on products made by SR companies, and losing $\$ 1000$ in annual investment returns by investing only in the stock of SR companies, an SR person can switch her market purchases to SR bad companies, and take the $\$ 2000$ a year that she has earned via such a switch and invest in non-market strategies, such as litigation and lobbying, designed to induce the bad companies to improve their performance.

However, just as an individual's market decision to avoid its products and stock likely to be of trivial significance to a large company, so too is the amount that an individual saves (and earns) by buying such a company's products and stock likely to be much too small to finance effective non-market strategies. A bad company saves some amount c by cutting its expenditures on environmental compliance, degrading labor practices and the like. The amount that a company will rationally spend to defend itself against private or public

119 [Cite to AER article on college town buying to keep small businesses in business] 
regulatory action to remedy its performance is determined generally by this compliance cost saving, c, plus any fine or damages it expects to pay. These amounts will typically dwarf the amount that an individual consumer or investor could invest in lobbying or litigation against the company. Just as the individual consumer or investor's market influence is too small to effect corporate behavior, so too is her non-market influence likely far too small to change behavior.

For an individual consumer or investor, both her individual market as well as her non-market strategies can be effective only if they are part of a larger, collective market or non-market effort. As I discuss below, as a theoretical matter it is clear that the presence of a sufficiently large number of SR consumers effectively will indeed create an incentive at least some firms to differentiate their products as ones that are sold by a socially responsible, environmentally sensitive company. ${ }^{120}$ Similarly, the presence of a large number of SR investors can shift the demand curve for a firm's stock. Given the likely effectiveness of such collectively expressed market preferences, if SR consumers and investors expect that their market strategies will be followed by a sufficiently large number of like-minded people, then such market strategies may indeed be rational and effective.

It may be objected that such collective market behavior is not rational after all, because if there are indeed a large number of SR consumers and/or investors, then there is an incentive for an SR person to make her market decisions to serve her own narrow selfinterest, leaving it to others to use the market to punish bad companies and reward good ones. As has been shown for altruistic behavior generally, any incentive for such free-riding will generally be offset by the fact that SR consumers and investors get direct utility or disutility from their market decisions. That is, an SR investor or consumer already feels bad,

${ }^{120}[$ See infra discussion at notes _ 
by definition, about sacrificing principle for profits, and the knowledge that others are doing what she really should be doing cannot but help her do what she considers to be the right thing.

Nonetheless, the likely success of both collective market and non-market action is likely to be depend upon the relative institutional capabilities for collective action of these two types. As I discuss below, firms seem to be highly, and indeed surprisingly responsive to even the threat of a consumer boycott. This seems largely due to the existence of very effective collective institutions for organizing and also communicating information about such boycotts. Organizations such as Greenpeace and the Rainforest Action network have been very effective not only in targeting specific practices of specific firms, but in generating mass knowledge of the boycotts they have sponsored and their effectiveness. It seems that many SR consumers may themselves get utility directly from participating what they know to be group action.

While this may be true for consumer product boycotts, where the knowledge of collective action may spread quickly, there may never be solid evidence of the success of individual consumer or investor decisions to favor "good" companies. Here, collective action seems to require the formation of buying collectives, where the collectives establish rules for screening product purchases so that they buy only from SR good firms. It is, however, a much different thing to establish an ongoing market for SR good firms to thrive within than to temporarily boycott an SR bad firm to induce it adopt certain discrete practices (or to refrain from other actions). Participation in a buying collective is a much more

Ultimately, an SR consumer or investor's choice among expressing her SR preferences indirectly - by making neoclassical decisions in the market and then contributing 
what she earns (or saves) to collective action institutions that take non-market action -versus expressing her SR preferences directly in her market choices is likely to vary primarily with the larger political, social and legal culture. In European countries, where individual lawsuits to contest environmental standard-setting are not generally allowed (such individual lawsuits being reserved for challenges over site-specific permits), a rational SR consumer or investor will look to take direct, market action. In the United States, by contrast, where there are more opportunities for effective public interest group litigation, the choice is likely to tilt toward expressing SR preferences indirectly.

B. CSR as a Credence Good: Non-governmental organizations (NGO's) as Market Information Providers

Institutions for collective action by SR consumers and investors - environmental groups such as Greenpeace and the Rainforest Action Network -- play an important role not only in ensuring SR consumer and investors that the actions they take will be part of a collective effort that may actually influence corporate behavior, but in determining the preferences of such SR actors. Such non-governmental organizations (ngo's) play a crucial role in making the SR market. Unlike, for instance, the performance of an automobile or the taste of an allegedly fine wine (goods economists sometimes call experience goods), a consumer or investor cannot directly observe where a particular company's environmental performance falls along the spectrum of good to bad. The things that SR consumers and investors care about - the environmental, health and safety effects of a company's operations - are what economists call credence goods, goods that the consumer (or investor) never actually learns about fully, even after buying and consuming the good (or investing in the stock). 
The basic efficiency problem in markets for credence goods is that consumers may get the wrong quality - a quality other than that which they demand - either mistakenly, or intentionally, as when a seller deliberately charges a high quality price for what is actually a low quality good or service. ${ }^{121}$ Credence goods markets exhibit an extreme form of information asymmetry, and so are subject to the general adverse selection result that asymmetric information may destroy market equilibrium - as consumers discount the price they pay for their lack of knowledge, leaving only the low quality suppliers in the market, which then induces a further discounting, and further producer exit, toward the eventual elimination of any but the lowest quality producer. The economic literature has identified two possible solutions to the adverse selection problem in credence goods markets. One is for the consumer to get independent information ex ante regarding the quality provided by a particular good or service producer (either by getting multiple opinions, as in the case of professional services such as medical care, or from a third party inspector or certification agency or firm). The other fix is ex post legal liability, as for fraudulent misrepresentations regarding quality. Both of these assume at least limited verifiability of actual quality. ${ }^{122}$

Observe that these are precisely the same solutions that arose in my earlier discussion of how firms might attempt to credibly commit to voluntarily disclose environmental regulatory risks. Just as firms have an incentive to conceal (or at least not reveal) negative information, so too do they generally have an incentive to exaggerate their

\footnotetext{
121 This very nice summary of the problem in credence good markets, plus a succinct literature summary and interesting new model, is provided by Uwe Dulleck and Rudolf Kerschbamer, Of Doctors, Mechanics and Computer Specialists, or Where are the Problems with Credence Goods?, University of Vienna Dept. of Econ. , Working Paper No. 0101 (January, 2001).

122 See the discussion in Timothy J. Feddersen and Thomas W. Gilligan, Saints and Markets: Activists and the Supply of Credence Goods, 10 J. Econ. \& Manage. Strat. 149, 150, 150 n.4 (2001). For an analysis with imperfect monitoring by a third party, see Stefanie Kirchoff, Overcompliance, Labeling, and Lobbying: The Case of Credence Goods, University of Maryland Dept. of Agricultural and Resource Economics Working Paper No. 98-25 (1998); for an interesting demonstration that capacity constraints can generate non-fraudulent
} 
positive environmental performance. Indeed, to get the business of SR consumers and investors -- who want both to avoid dealing with SR bad firms and to deal only with SR good firms - it would seem that firms have an incentive to both exaggerate the things they do that SR actors praise and hide the things they do that SR actors blame.

Faced with these incentives on the part of firms (if these are indeed the incentives of a typical firm, about which I shall have more to say below), SR actors may find it difficult or impossible to implement their preferences in actual decisions - to figure out which firms' products or stock to buy, or avoid -- unless they can get firm-specific information about corporate CSR from a trustworthy third party certifier. Indeed, CSR, as a product or service attribute, is an extreme form of credence good, for unlike many credence services, such as medical care or automobile repair, in the case of CSR the question is not is right for a particular consumer, so that shopping for second opinions may generate information, but rather what a particular company really does or does not do. Even worse, as I argued earlier in discussing incentives for voluntary disclosure of environmental risks, unlike a medical procedure - which either is or is not what the patient needs for a particular condition - the fact that a firm currently exhibits "good" environmental performance does not mean that it will continue to do so in the future. For SR actors to translate their preferences into actual market decisions, they need not only information about what companies are currently doing, but also information about what the companies will do in the future.

NGO's are the logical solution to the need for market certification in SR markets. Provided that it has sufficient vulnerability to market reputation, an NGO will have a strong economic interest in providing reliable and credible firm-specific CSR information. Given

equilibria even without third party certification, see Winand Emons, Credence Goods and Fraudulent Experts, 28 Rand J. Econ. 107 (1997). 
this information, SR investors and consumers can make their market decisions, perhaps following the explicit advice of the NGO.

The qualification in the preceding paragraph is crucial. For NGO's to be reliable certifiers, it must be that they will pay a real market penalty if revealed to have colluded with the companies that they are ostensibly judging, or if revealed to simply be inaccurate in their assessment of actual CSR performance. Such a market penalty is most likely to exist when: a) there is competition in the ngo market, so that SR actors have lots of alternatives to turn to if dissatisfied with advice from a particular organization; b) ngo's are themselves strongly dependent upon contributions from SR consumers and investors, as opposed to the firms that they evaluate; and c) there exist other sources of information regarding firm environmental performance - such as disclosures required and certified by government agencies - that SR actors can use to verify their ngo's report. Thus government monitoring is likely to compliment, rather than substitute for ngo monitoring.

C. Institutional SR: Corporate Supply Chain Management and Institutional Investors

Before turning to what is in a sense the ultimate question for SR markets - will the presence of SR consumers and investors really change firm behavior? - It is important to pause to consider what may be the most important category of SR actors, firms themselves, and institutional investors. Urged on by their ngo watchdogs, firms ranging from Home Depot (in its purchasing) and Citicorp (in its lending policies) to McDonald's (in their packaging) have advertised as one of their primary acts of CSR the adoption of new environmentally friendly (or, in contemporary jargon, "sustainability") policies and objectives in their own market transactions. Whether as buyers or sellers, firms have seemingly introduced SR objectives into their own market decisions. Similarly, many of the largest 
institutional investors - pension funds such as CALPERS, and mutual funds such as Calvert - have broadcast that as long-term investors, they care as much about what the companies they invest in do for the world, as they do about the financial returns those companies generate for investors.

One view of such institutional SR is that it is more or less identical to individual SR, in that it simply involves companies making charitable, altruistic contributions to social welfare at the expense of their bottom line financial performance. ${ }^{123}$ I believe that this view is mistaken. Such institutional SR is quite different than individual SR consumers and investors I have been considering. Socially responsible institutional investors are much more akin to ngo's than to individual investors. Indeed, socially responsible mutual funds are the ngo's of the investment world. Like individuals, these funds employ both market and nonmarket strategies. The primary, complimentary market strategies are avoidance screening -not investing in companies that the investor considers to be "bad" -- and positive screening - buying the stock of companies who have been identified as meeting certain standards for corporate conduct and whose conduct along these dimensions is superior within a particular industry class. ${ }^{124}$ The non-market social investment strategy involves shareholder activism in filing and voting on proxy resolutions pertaining to social and environmental issues.

SR institutional investors are thus not acting out their own preferences, ${ }^{125}$ but rather serving as an institution for SR investor collective action. As for SR corporate transacting, it is true that companies are not themselves certifying the environmental or social soundness

\footnotetext{
${ }^{123}$ For an elegant model in which CSR is modeled simply as a charitable contribution by a company, but in which SR firms may not need to pay a market penalty for such altruism in the form of a lower stock price (essentially because when all consumers prefer such charity, it is irrelevant whether the firm makes the contribution or consumers do), see Arthur A. Small and Joshua Graff Zivinm, A Modigliani-Miller Theory of Corporate Social Responsibility (Columbia University, August 2002).

124 These are discussed briefly in Social Investment Forum, 2003 Report at 3, 5-6.
} 
of those transactions. Rather they look (as in the examples of Home Depot and McDonald's) to ngo's to certify that they have indeed done the environmentally or socially responsible thing. But to say that such behavior reflects corporate SR preferences seems farfetched. Despite the vast amount of rhetoric about "caring," and "concerned" companies, the evidence strongly suggests that corporate SR is adopted in response to external pressures - either from regulation (existing or threatened), or from ngo market and non-market actions (often to stave off ngo threats) - and designed to serve the long run goal of economic value maximization. Hence the question is not why companies "care," but how and when they should be expected to respond to the pressures exerted by SR consumers and investors. It is to that issue that I now turn.

\section{What Kinds of Incentives Does the SR Market Create?}

Supposing that at least some consumers and investors find it best to express their preferences for SR corporate behavior directly, through their market buy and sell decisions, the real question for policy is whether the aggregate effect of such individual decisions will indeed influence companies to improve their environmental performance. In both product and stock markets, the basic incentive offered by SR actors is to offer a reward, in the form of increased demand, or higher price, for SR companies to undertake the costly investment that improved SR performance requires. A growing body of work shows, moreover, that firms will indeed be induced by the rewards (and price penalties) offered by SR consumers

125 The behavior of public pension funds such as CALPERS is an exception to this statement. There is abundant evidence that the managers of these funds are pursuing their investment objectives so as to maximize their own private objectives, such as political advancement. [See Romano] 
and investors to differentiate themselves, with some making costly investments in environmentally friendly production. ${ }^{126}$

The question, however, is whether this reward will be sufficient to induce firms to make real, credible investments, or will instead lead only to a public relations façade designed where firms spend minimal amounts to persuade consumers and investors that they are socially responsible, but there is no actual improvement in environmental or social performance.

1) When, if Ever, Will Signals of Corporate Social Responsibility be Informative? The analysis above has already supplied one answer to the question in this subsection: Credible communication about CSR is to be expected when there are reliable, equally credible third party certifiers of such communications. This section explores the possibility for credible communication about CSR in the absence of such credible third party verification. It may be understood as asking whether the market - unaided by such third party certification, or by legal liability for false CSR assertions - is likely to provide the information about CSR that SR actors demand.

The primary obstacle to a happy answer to this question is that if SR consumers and investors do indeed generate market, bottom line rewards for firms that establish reputations for CSR, then there will be an incentive for companies with no particular interest in making the costly investments required to actually achieve superior environmental performance what might be called "bad actors" - to mimic the behavior of good actors. That is, if a

\footnotetext{
126 See, for example, Klaus Conrad, Price Competition and Product Differentiation when Consumers Care for the Environment (FEEM Working Paper, July, 2003); Clas Eriksson, Can Green Consumerism Replace Environmental Regulation - A Differentiated Products Example, 26 Resource \& Energy Econ. 281 (2004); Gregory S. Amacher, Erkki Koskela and Markku Olllikainen, Environmental Quality Competition and EcoLabeling, 47 J. Envl. Econ. \& Manage. 284 (2004). In the investor context, the basic effect of SR investors in shifting the demand for the firm's stock is demonstrated by Michael S. Knoll, Ethical Screening in Modern Financial Markets: The Conflicting Claims Underlying Socially Responsible Investment, 57 Bus. Lawyer 681 (2002).
} 
company really does get tangible economic benefits from persuading consumers, investors and regulators that it is a good actor, then there is an incentive to establish a reputation as such an actor, regardless of whether the reputation is warranted by good actions. When both good and bad actors purport to "walk the talk" of corporate environmental concern, such signals (or communications, as I shall use the two interchangeably) are no longer informative regarding the actual level of corporate commitment.

Economists call such a situation an uninformative pooling equilibrium. In such an equilibrium, the money spent attempting to persuade investors, consumers and regulators that firms are good actors is a social waste, because it does not generate any socially valuable information. From an economic point of view, the better state of affairs is when social responsibility signaling is informative. One of the central results in contemporary economics is that for such signaling to be informative, it must be the case that the cost of such signaling to firms varies with their actual level of expenditure on environmental performance. Credible signaling requires that the firm's (marginal) cost of signaling environmental commitment is lower, the higher is the firm's actual level of investment to reduce or mitigate the adverse environmental impact of its activities or to enhance and restore the natural environment. $^{127}$

Some signals of corporate environmental performance seem to meet these requirements, but the existing regulatory structure does not create incentives for such informative signaling investment. If it is true that the higher the level of prior investment, the lower is the firm's cost of meeting tougher future environmental performance standards, then such prior investment would be an informative signal of firm type, where type is understood to mean the firm's future expected environmental performance. Most command 
and control regulation, however, is not performance-based, but rather emissions rate based. Under such command and control regulation, newer, cleaner technologies are often effectively penalized by being required to achieve a much lower emissions rate than is required of older technologies. In this way, the command and control system discourages technological innovation and change. More to the present point, it also discourages precisely the kinds of investments that might well be informative, credible signals of present and future environmental performance that are needed to effectuate the SR market.

It is true that firms' regulatory exposure varies tremendously, both across different industries, and by firm (and facility) size. Pulp and paper mills and oil refineries, for example, face much lower regulatory costs than does even a mass retailer such as Wal-Mart. Firms vary in their visibility to SR investors and consumers. Such variation can clearly create variations in the costs and benefits of attempting to signal social responsibility. But this variation does not necessarily lead to credible signaling. Indeed, if one firm within an industry is larger, with higher visibility than a second firm, then one would expect the first to invest more to try to persuade SR actors that it is a good type than will the second. This does not make its communication any more credible. Indeed, the two firms are in a very real sense not even playing the same game.

\section{2) Corporate Cheap Talk}

Many environmentalists and other social activists are also skeptical about the viability of such informative signaling equilibria. A common allegation is that many large corporations engage in so-called "greenwashing": while running advertisements in newspapers and magazines that broadcast the firm's commitment to "ethical" environmental

127 The clearest formal demonstration of this result of which I am aware is contained in Jean-Jacques Laffont and David Matrimont, The Theory of Incentives 28-81, 387-390 (2002). 
and labor practices, their actual practices remain unchanged. ${ }^{128}$ From a game-theoretic point of view, greenwashing involves communication that is "cheap talk" in that it costs the firm virtually nothing (relative to overall firm budgets). ${ }^{129}$ One of the more interesting results in modern game theory is that even cheap talk can be informative. However, although there are various routes to this result, it generally holds only under the following condition: given that the talk is believed to be true (that listeners believe the company is eco-friendly when they see a one page spread with jungles and monkeys in their favorite magazine) only the firms for which the statement is literally true actually are better off sending the statement. ${ }^{130}$ It is not easy to characterize the existing market conditions with respect to corporate SR talk. Available empirical evidence suggests that even as corporate SR reporting is becoming increasingly widespread, the link between the reports and actual environmental and social performance is unclear and difficult if not impossible to ascertain. ${ }^{131}$ At the same time, there is still considerable variation in the length and content of corporate SR reports. In my view, the variation is so large that one cannot describe the existing state of affairs as one in which every corporation is communicating a message of commitment to CSR. In other words, if corporate SR communications are cheap talk, then we seem to have an equilibrium that is informative, rather than pooling.

\footnotetext{
129 Shell's recent announcement that it will avoid exploring or drilling for oil on sites designated by the United Nations as World Heritage areas provides a vivid recent example of such cheap talk: Shell had no plans to explore or drill for oil in any of these sites. See Heather Timmons, Shell to Avoid Oil Drilling at Sites Listed by Unesco, NY Times, September, 2003 [get precise cite]. The strategy of "talking the talk" while continuing to view environmental compliance in purely neoclassical terms, cost minimization terms appears to be exemplified by Holcim, a cement manufacturing firm with a long history of recurrent violations at its American plants, but whose owner, Stephen Schmidheiny and family, have been major forces in creating the Business Council for Sustainable Development. See Lucy Komisar, USA Holcim: Global Greenwasher, CorpWatch, August 26, 2002, available at www.corpwatch.org/news?PND.jsp?artricleid=3709 (last visited March 3, 2003).

130 [add cite to Farrell and JET article with little summary of alternative refinements to eliminate pooling]

131 See, for example, Ans Kolk, More than Words? An Analysis of Sustainability Reports, 3 New Acad. Rev. 59 (2004).
} 
Game theory teaches that for such an informative equilibrium to exist, it must be that firms that do not send a CSR message are better off with whatever inference it is that the market draws from their failure to send such a message than they would be with the inference drawn were they to send such a message. So the question is: just what is that the market of SR consumers and investors think they are learning from the fact that a company puts out a SR statement?

The answer, I believe, is once again to be found in the parallel between the incentive for voluntary disclosure of bad environmental news and that for affirmative communication of good environmental news. By speaking out about its CSR, a firm reveals that its operations have potentially large social and environmental impacts. For firms in high visibility, heavily polluting industries, this impact is already obvious to market participants, both neoclassical and SR. Those firms are trying to convince the market that they have actually undertaken various commitments to improve their future performance, to cut the externalities generated by their operations. For these high visibility firms, failure to issue an SR statement may well be taken to indicate lack of concern, a lack of concern that may well be costly to both types of market participants.

Now consider those firms that market participants have traditionally presumed to have lower impact operations. For such firms, whatever positive information is conveyed by the issuance of an SR statement - that the firm cares about the externalities generated by its operations - may well be overwhelmed by the negative information revealed by the fact that it has reported at all - information to the effect that its operations are having a significant environmental impact.

Putting these two pieces together, we have two basic predictions. The first is that firms of a particular size and in a particular industry are unlikely to be concerned with issues 
of CSR until regulators, or perhaps ngo's have targeted them and publicized their activities as having a high environmental impact. Second, once such impacts have become well known, one would expect to see that all firms in a particular, targeted size/industry category issue CSR reports. From these two predictions, there is a final implication: from the fact that firms in a particular size/industry category uniformly issue CSR reports, one can conclude that the category is widely perceived to have a high environmental and social impact; such reports do not, however, generate information on the relative economic and social performance of firms within such a category.

E. Some Selected Evidence on the SR Market

1) Who Talks? Incentives for CSR Reports and other Disclosures

Companies can communicate their environmental and social performance through a variety of outlets, including print and television advertisements, annual reports, and special CSR reports. Perhaps my central prediction regarding CSR communication is that only those firms that are already have high regulatory and political visibility and which are known to have a large social and environmental impact are likely to benefit from CSR communications. For other firms, the information revealed by a CSR report - that the firm has such a high social and environmental impact that a CSR report is warranted - will likely more than offset the relative good news contained in the report - that the company is taking steps to lower its external impact.

The industry group within which a firm is categorized proxies well for its perceived social and environmental impact and regulatory exposure. Indeed, industry group is such a good proxy that it is one of the primary screens used by the SR investment funds discussed 
below. ${ }^{132}$ The existing pattern of firm CSR disclosures by industry group strongly confirms my central prediction regarding CSR talk. Table 1 depicts the results of a 2001

PricewaterhouseCoopers survey of disclosure by the top 100 global companies. ${ }^{133}$

As Figure 1 shows, most of the industries in which a majority of the large companies surveyed publish CSR reports are those - autos, energy and utilities, industrial products and pharmaceuticals - whose production processes and/or products are well known to have a high external impact, and which are quite heavily regulated. Indeed, other than these, only the retail and consumer sector - where the SR consumer market may itself create an independent reason for CSR advertising - has a majority of large firms publishing CSR reports.

\footnotetext{
132 See discussion infra at notes _ to _. . As stated by a recent report from the United Kingdom's Environmental Agency, “[t]he type and scale of a company's environmental impacts are largely dependent on the business activities in which it is involved, i.e. the industry sector to which it belongs." Trustcost and Environment Agency, Environmental Disclosures in the Annual Reports and Accounts of Companies in FTSE All Share (July, 2004)(available at www.environment-agency.gov.uk).

133 Graham Gilmour and Aaron Caplan, The Future of Corporate Reporting (2001), available at www.pwcglobal.com/extweb/pwcpublications.nsf/DocID/F021151B26E05EBA80256B05003FAC53 (last visited April 19, 2005).
} 


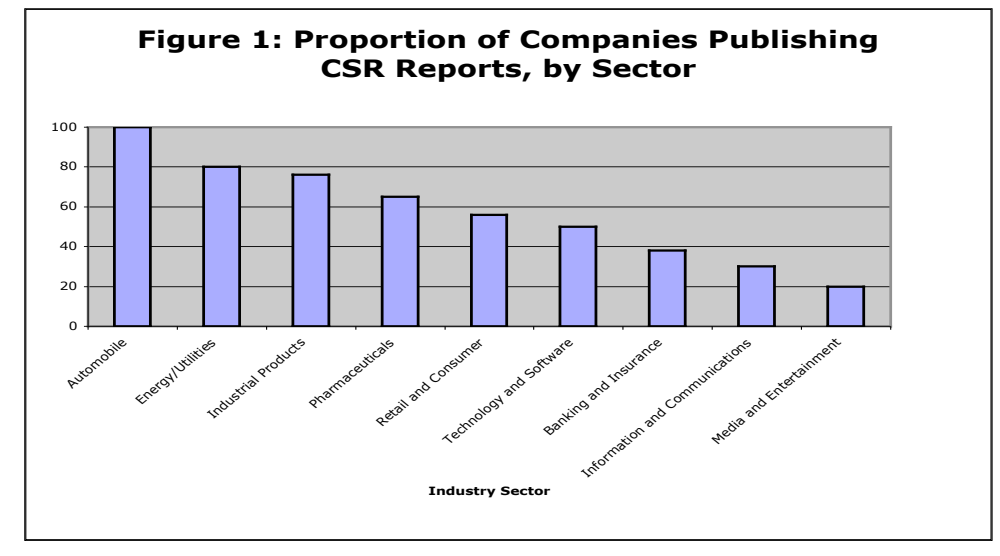

More recent evidence on CSR communication by industry sector confirms the general pattern depicted by Figure 1. Because carbon dioxide emissions are currently unregulated, and there is little firm-specific information about such emissions, firms generally have no wish to alert the market to the potential cost that global warming regulation might impose upon them. ${ }^{134}$ Of the top 100 firms in a 2004 Standard \& Poor's/UNEP report ranking firm practices in non-financial reporting, almost one-quarter $(23 / 100)$ were energy or utility firms, while 52 of 100 were from four sectors -- materials, energy/utilities, transportation/automobile manufacturing, and pharmaceuticals. ${ }^{135}$ Finally, a recent comprehensive report by the U.K. Environment Agency on environmental disclosures by companies included in the FTSE all share index likewise finds a direct relationship between the regulatory visibility and known external effects of a company, as

\footnotetext{
${ }^{134}$ Doug Cogan, Most U.S. Firms Still Not Disclosing Climate Risks, IRRC Corp. Social Issues Reporter 12 (Dec. 2003).

135 Standard \& Poors, UNEP and SustainAbility, The Global Reporters 2004 Survey of Corporate Sustainability Reporting: Risk and Opportunity -- Best Practice in Non-Financial Reporting (2004)(available at www.sustainability.com/insight/research-article.asp?id=128 )(last visited April 19, 2005).
} 
disclosure rates vary directly with the perceived environmental impact (that is, the probability that a company discloses impacts on a particular resource are higher, the higher is the company's impact on that resource), and large companies are systematically more likely to disclose than are small companies. ${ }^{136}$

\section{2) Consumers}

The most striking, and in some ways surprising, evidence regarding SR consumers is the apparently large impact of consumer boycotts (to use my earlier terminology, a collective market strategy). Boycotts such as the Greenpeace-led boycott of Shell over its plan to sink the Brent Spahr oil platform in the North Sea, the Rainforest Action Network's consumer campaign against Burger King's purchase of beef grown in deforested rainforest areas and the multi-organizational campaign against Monsanto's genetically modified food products all had a relatively swift and dramatic effect in changing firm behavior. ${ }^{137}$ On the other hand, the evidence is also clear that consumer boycott announcements do not always work, either because consumers simply don't respond to the call for a boycott, or because the firm does not change its behavior and simply rides out the boycott period. ${ }^{138}$ Available evidence suggests that calls for consumer boycotts succeed only when the threatened corporate actions are widely perceived to be highly egregious in their effects on the environment, working conditions and other social conditions. ${ }^{139}$ Yet when boycotts do succeed, it seems that they do so precisely as the theory would predict, by causing a range of severe short term effects - in the form of decreased sales, and intensely adverse media coverage - rather than

\footnotetext{
${ }^{136}$ See Trucost \& U.K. Environment Agency, Environmental Disclosures, supra note _ at _ , and _.

137 See Ethical Consumerism: Consumer Campaigns, available at http://www.oneworld.org/guides/ecg/campaigns.html. Thomas Friedman, Elites Worried About Increasing Consumer Boycott Power, New York Times, June 1, 2001.

${ }^{138}$ See David P. Baron, Facing-Off in Public, Stanford Social Innovation Review (August, 2003); Monroe Friedman, Consumer Boycotts (1999).
} 
by causing any change in firm market value. ${ }^{140}$ As an activist in the 24-year campaign to end

Nestle's marketing of powdered milk in developed countries recently put it, successful boycotts are an "instantly understandable signal that something is seriously wrong with a company." ${ }^{141}$ Especially outside the United States, consumer boycotts seem to be becoming an increasingly frequent means of attempting to influence corporate behavior. ${ }^{142}$

Evidence that consumers have and are expressing SR preferences in their day-to-day market purchasing decisions is somewhat more mixed. Whether consumers can express such a preference depends, of course, upon whether they have information regarding SR product characteristics at the time they make their purchase decisions. Evidence that companies do indeed have an incentive to generate such information to attract such consumers comes in a variety of forms, including corporate investment in costly "ecolabeling" to advertise these environmental product attributes, the production and dissemination of reports on the firm's environmental, health and safety accomplishments, and public relations campaigns including costly media advertisements. ${ }^{143}$ As succinctly described by Russell and Clark, ${ }^{144}$ there are a variety of SR product labeling schemes. They

\footnotetext{
${ }^{139}$ Jill G. Klein, Andrew John and N. Craig Smith, Exploring Motivations for Participation in a Consumer Boycott, London Business School, Centre for Marketing Working Paper No. 01-701 (November, 2001).

${ }^{140}$ For example, the Greenpeace-initiated boycott of Shell caused a decrease in its German sales of from 20 to 30 per cent. See Baron, supra note _ . The effects of boycotts on firm market value have by contrast been small. See The Effect of Socially Activist Investment Policies on the Financial Markets: Evidence from the South African Boycott, Siew Hong Teoh, Ivo Welch and C. Paul Wazzan, 72 Journal of Business 35 (1999). ${ }^{141}$ Quoted in, Let's Hear it for the Boycott, The Observer, Sunday, March 2, 2003.

142 Ethical Consumer magazine now lists 60 active boycotts [add cite]. In Britain, a government minister recently warned the oil industry that it faces a very real threat of consumer boycotts if it does not join in a global drive to eliminate government corruption in the developing world. See Charlotte Denny, Short Warns of Oil Boycott over African Corruption, The Guardian, Feb. 11, 2003. In the United States, senior citizen groups are beginning to take direct action against pharmaceutical industry practices that they perceive as contributing to high prescription drug prices. See Minnesota Senior Federation, Mulitistate Consumer Boycott of GlaxoSmithKline Called, Feb. 20, 2003. Available at www.mnseniors.net./tumsdown/030220mediaadvisory.html

${ }^{143}$ David Baron, Private Politics, Corporate Social Responsibility and Integrated Strategy, 10 J. Econ. \& Manage. Strategy 7 (2001) has dubbed such moves "strategic social responsibility."

${ }^{144}$ Clifford S. Russell and Christopher D. Clark, Public Information Provision as a Tool of Environmental Policy, Draft III, p. 3 (March, 2003).
} 
vary both in their sponsorship - industry, NGO or government - and also in the kind of product information that the label certifies - ranging from a report card - like grade aggregated from various product and producer attributes to information on specific product attributes or dimensions. From this variety of experience, a few lessons have been learned. As exhibited most dramatically by the public panic over that ensued over reports that apple juice was contaminated by the pesticide Alar, ${ }^{145}$ consumers have long been concerned to varying degrees about pesticide residues on food, ${ }^{146}$ and are willing to pay premium prices for the perceived safety of pesticide-free organic produce. ${ }^{147}$ Organic food sales have increased by more than 20 per cent per year for over a decade, and according to the Organic Trade Association, sales of organic products in the U.S. are now over $\$ 6$ billion per year. ${ }^{148}$ Consumer surveys similarly show that consumers are willing to pay premium prices for seafood that is certified to be safe. ${ }^{149}$ Conversely, consumers who believe that genetically modified (GM) foods pose a threat to human health would only consume GM foods if they were discounted by at least $40 \%$ relative to the price of non-GM foods. ${ }^{150}$

\footnotetext{
${ }^{145}$ Alar was the trade name for a plant growth regulator used to keep apples firm and red during storage. The TV broadcast of results of a Natural Resources Defense Council risk assessment claiming that eating Alar on apples caused between 1 out of every 4200 schoolchildren to get cancer before the age of six caused a consumer panic, and a precipitous decline in apple consumption that caused apple growers to persuade Alar's manufacturer to permanently remove the product from the market. For a more extended description of the Alar episode, see Robert V. Percival, Christopher H. Schroeder, Alan S. Miller and James P. Leape, Environmental Regulation: Law, Science and Policy 387-393 (4th ed. 2003).

${ }^{146}$ See Riley Dunlap and Curtis Beus, Understanding Public Concerns About Pesticides: An Empirical Examination, 26 J. Consumer Affairs 418 (1992); Eileen Van Ravenswaay and John Hoehn, The Impact of Health Risk Information on Food Demand: A Case Study of Alar and Apples, in Julie Caswell, ed., Economics of Food Safety 155 (1991); JC Buzby and JR Skees, Consumers Want Reduced Exposure to Pesticides on Food, 17 Food Rev. _ (1994).

${ }^{147}$ See G.D. Thompson, Consumer Demand for Organic Foods: What we Know and What We Need to Know, 80 Amer. J. Ag. Econ. 1113 (1998); J. Kidwell, Explaining the Choice of Organic Produce: Cosmetic Defects, Prices, and Consumer Preferences, 80 Amer. J. Ag. Econ. 277 (1998).

148 [to be verified with OTA]

149 For similar evidence in the context of seafood safety, see Cathy Roheim Wessells and Joan Gray Anderson, Consumer Willingness to Pay for Seafood Safety Assurances, 29 J. Consumer Affairs 85 (1995).

${ }^{150}$ Because European retailers do not carry genetically modified foods, it is not possible to directly observe consumer choices there between genetically modified and traditional foods. In the U.S., genetically modified foods are sold, but are not labeled as such, so there too researchers cannot test actual market choices over the
} 
That consumers are willing to pay more for food that they perceive to be safe merely means that there are a number of consumers with SR preferences in the very narrow sense that they care about food product safety as well as taste, appearance and other traditional characteristics. It does not mean that lots of consumers are willing to pay more for food that is not any safer or better tasting but which is grown under conditions that are less environmentally harmful - whether, that is, consumers have strong SR preferences. What evidence does exist, however, tends to suggest that labeling a product as environmentally or socially sound in this broad sense does make a difference to some consumers. While most of the studies involve hypothetical survey questions (e.g., "would you pay more for tuna labeled as "dolphin-safe"?), ${ }^{151}$ there are a few studies that have attempted to econometrically estimate whether people actually are paying more products that are certified to have been produced in an environmentally friendly way. Such studies have found that consumers will pay a price premium for certifications that tuna is dolphin-safe, ${ }^{152}$ that textiles have been produced with low or no pesticide use $\mathrm{e}^{153}$ and that their electric power is "green" (viz., is not generated by coal-burning plants). ${ }^{154}$ These and other studies suggest that there exists a set of

two options. Recent experimental work, however, shows that while some European consumers will refuse to purchase genetically modified foods at any price, most will purchase such foods if the price is low enough. Charles Noussair, Stephane Robin and Bernard Ruffieux, Do Consumers Really Refuse to Buy Genetically Modified Food? 114 Econ. J. 102 (2004). At least one economist has estimated that it would take a price discount of up to 40 per cent to induce such consumers to buy GM-modified foods. See Jim Giles, Europe Finds Transgenic Food Hard to Swallow, 424 Nature 116 (2003). For evidence from surveys of hypothetical consumer choice, see Jill J. McCluskey, et. al., Consumer Reponses to Genetically Modified Food Products in Japan, 32 Ag. \& Res. Econ. Rev. forthcoming (2003); Kristine Grimsaud, et.al., Consumer Attitudes toward Genetically Modified Foods in Norway, IMPACT Center Working Paper (2003).

${ }^{151}$ As observed, and briefly catalogued by Russell and Clark, supra note

152 Mario F. Teisl et.al., Can Eco-Labels Tune a Market? Evidence from Dolphin-Safe Labeling, 43 J. Envl. Econ. \& Manage. 339 (2002).

${ }^{153}$ See Wesley Nimon and John Beghin, Are Ecolabels Valuable? Evidence from the Apparel Industry, 81 Amer. J. Ag. Econ. 801 (1999); Wesley Nimon and John Beghin, Ecolabels and International Trade in the Textile and Apparel Market, 81 Amer. J. Ag. Econ. 1078 (1999);

${ }^{154}$ Brian Roe et.al., U.S. Consumers' Willingness to Pay for Green Electricty, 29 Energy Policy 917 (2001). See also other studies cited by Russell and Clark, supra note _. 
consumers who actually do translate their preferences for certain public attributes of firm performance into private consumption decisions. ${ }^{155}$

2) SR Investors

a) SR Investors and the Relationship Between Environmental and Financial Performance

It is clear that SR investors do exist. Recent surveys reveal that a large fraction of private investors want more information pertaining to such dimensions of firm performance as privacy, labor and environmental policies, and that institutional investors consider this same sort of information relevant to their investment decisions. ${ }^{156}$ There are now a number of companies, such as Innovest Strategic Value Advisers and Thompson Financial's Social Investing Research Service, who provide systematic data on corporate social performance to both traditional and social responsibility - oriented institutional investors. ${ }^{157}$ Such "social" investment funds - which weigh corporate social and environmental performance in deciding where to put their money - have grown rapidly, both in terms of numbers and amount invested. ${ }^{158}$ According to the Social Investment Forum, assets held by socially responsible institutional investors in the United States ${ }^{160}$ increased from $\$ 639$ billion in 1995

\footnotetext{
${ }^{155}$ See Maria L. Loureiro, Jill J. McCluskey and Ron C. Mittelhammer. "Valuing Eco- Labels in the Market Place." Forthcoming in Advances of Economics Research. Nova Publishing, Inc., 2003.

${ }^{156}$ Michelle Chan-Fishel, After Enron: How Accounting and SEC Reform Can Promote Corporate Accountability While Restoring Public Confidence, 32 ELR 10965, 10968 (August, 2002).

${ }^{157}$ Chan-Fishel, supra note _ at 10969.

${ }^{158}$ Cynthia A. Williams, The Securities and Exchange Commission and Corporate Social Transparency, 112 Harv. L. Rev. 1197, 1287 (1999).

159 This is a broad category that includes any investment institution that 1) employs one or more social screens as part of a formal institutional policy, or 2) sponsors shareholder resolutions on social issues or has an active social investment committee that determines proxy-voting policy on social issues before the issues come up fot vote, or 3) is a Community Development Financial Institution (CDFI). For this definition, see Social Investment Forum, 2003 Report on Socially Responsible Investing Trends in the United States i (December, 2003) (available at www.socialinvest.org/areas/research).

${ }^{160}$ Social Investment Forum, 2003 Report at i.
} 
to $\$ 2.32$ trillion in $2001 .^{161}$ Even taking account of a slight decline (to $\$ 2.16$ trillion) over the 2001-2003 bear stock market period, assets held by socially responsible investors have grown 40 per cent faster than all professionally managed assets in the U.S., and account now for a little over $11 \%$ of all investment assets under professional asset management in the U.S. ${ }^{162}$ The number of mutual funds using social screens grew from 139 in 1997 to 200 in 2003, increasing from 181 to 200 even during the bear market period of 2001-2003, when such funds continued to grow in terms of investor assets, while the overall mutual fund industry contracted. ${ }^{163}$

As noted above, it is theoretically possible that social screening could shift the demand curve for companies' stock, thereby creating an incentive for companies to avoid getting on the list of "bad" companies and/or acquire a reputation for good SR performance that would get them past positive screens. The ideal empirical test for such an effect would involve regressing reliable measures of corporate SR performance on, say, the amount of capital invested in SR funds, including as controls all other theoretically significant determinants of corporate SR performance. Such a study has not yet been done. Rather than focusing on the effect of SR investing on corporate SR behavior, the existing empirical literature has been preoccupied with investigating the financial performance of SR investors and companies with strong SR records. There have been a fair number of studies finding that companies with strong environmental ratings are also good stock market bets, ${ }^{164}$ but in general the findings of such studies have been ambiguous. ${ }^{165}$ Some find that firms with better

\footnotetext{
${ }^{161}$ Social Investment Forum, 2003 Report at i.

162 Social Investment Forum, 2003 Report at i.

${ }^{163} \mathrm{Id}$.

${ }^{164}$ Wagner and Schaltegger, supra note _ at 103.

165 In addition to the studies discussed supra notes _ to _, see R. Gray, R. Kouhy and S. Lavers, Corporate Social and Environmental Reporting: A Review of the Literature and a longitudinal study of UK disclosure, 8 Accounting, Auditing and Accountability J. 47 (1995); R.W. Roberts, Determinants of Corporate Social Responsibility Disclosure: An Application of Stakeholder Theory, 17 Accounting, Organizations and Society
} 
environmental performance are also better economic performers. ${ }^{166}$ Others find the opposite. ${ }^{167}$ This is unsurprising on my theory, for given the absence of a standardized measure of corporate social and environmental performance, results would be expected to vary with the particular SR performance measure used.

Moreover, even if there were a standardized measure of corporate social or environmental performance, no econometric study is likely to be able to separately identify the role of environmental performance in overall firm performance. The reason is that if firms with strong environmental performance are also strong, say, in marketing, finance and other typically key aspects of firm operations, then the correlation among the various measures of firm performance is too strong to permit statistical identification of the separate role of environmental performance. Indeed, the website of the oldest and largest SR mutual fund manager, Calvert, pitches its SR funds by arguing that "today's social and economic issues have a way of becoming tomorrow's economic problems...So, investing in companies that are committed to meeting the challenges of the future with an expanded view of corporate responsibility is more than just 'doing the right thing' - it also makes good business sense." 168 If Calvert is right, then corporate SR performance may simply be a relatively easily observable signal of future financial performance.

A larger empirical literature has explored the very practical question of whether SR investors pay a price, in the form of lower financial returns, for their SR preferences. This body of work has examined the financial performance of SR mutual funds relative to one or

595 (1992). For a general survey of this literature which attempts a more detailed explanation of the conflicting findings than I do here, see Joshua D. Margolis and James P. Walsh, People and Profits? The Search for a Link between a Company's Social and Environmental Performance (2001).

166 See, e.g., Cohen and Konar, supra note __; Butz and Planner, in Wagner and Schaltegger, supra note __ at 104.

${ }^{167}$ Cordeiro and Sarkis, cited in Wagner and Schaltegger, supra note _ at 104.

${ }^{168}$ See www.calvert.com/sri/htm. 
another benchmark for non-SR funds. Here too the findings are mixed. ${ }^{169}$ As summarized recently by Michael Knoll, SR screens have tended to cut out more large, established firms, generating portfolios composed disproportionately of shares in small, high tech firms.

Roughly speaking, SR funds have tended to deliver the same kind of returns one would get from holding a small cap index fund. ${ }^{170}$ With the bursting of the tech stock bubble, it is not surprising that the market performance of such "green" or "sustainable" funds has declined relative to the market. ${ }^{171}$ Even so, whether SR investors have paid a price for SR investing depends upon where they would otherwise have put their money. Since even financial economists now admit that it is possible to beat various market indexes by investing in various kinds of managed funds (at least over some time horizon), it is not at all clear what the relevant market alternative is for SR investors: that is, there is no reason to compare the return of SR funds to the return from holding various market index funds, because lots and lots of investors continue to prefer investing in one or more of the literally thousands of managed funds to investing in a fund that simply replicates the market portfolio.

b) The Uncertain Impact of Shareholder Advocacy

I use the term "shareholder advocacy" to include both the activity of making formal shareholder proposals for inclusion in the firm's proxy materials and also private advocacy, where a shareholder or group of shareholders negotiate directly with the firm's board of directors. In either form, shareholder advocacy is intended to influence corporate policies and performance. Shareholder advocates range from gadfly individual investors to the

\footnotetext{
${ }^{169}$ For a lucid summary of the evidence, see Michael S. Knoll, Ethical Screening in Modern Financial Markets: The Conflicting Claims underlying Socially Responsible Investment, 57 Bus. Lawyer 681, 697-700 (2002). For a careful recent study reinforcing and summarizing earlier findings, see Michael Schröder, Socially Responsible Investments in Germany, Switzerland and the United States, Zentrum fur Europaische Wirtschaftsforschung Discussion Paper No. 03-10.

${ }^{170}$ See Schröder, supra note _ f for the most recent evidence to this effect.

${ }^{171}$ Chao Lou and John Ganzi, 2001 Performance Review: Profit-Driven Sustainability Funds, Environment and Finance Enterprise, August, 2002.
} 
largest institutional investors, and their objectives likewise range from changes in corporate governance intended to improve the firm's financial performance, to changes in corporate SR performance. Shareholder proposals - brief statements submitted by a shareholder requesting specific managerial actions - are included in a firm's annual proxy statement (at the firm's expense) along with management's response to and recommendation on the proposal. $^{172}$

According to financial economists Diane Del Guerico and Jennifer Hawkins, ${ }^{173}$ until the late 1980's, shareholder proposals were used "almost exclusively" by individual investors and social activists. In the late 1980's, institutional investors began submitting proposals on corporate governance topics. Unlike earlier shareholder proposals, which had rarely got even $10 \%$ of the shareholder vote, corporate governance proposals have often received majority support. ${ }^{174}$ In 1992, in what legal commentators have called the first major changes to the SEC's proxy rules in nearly forty years, ${ }^{175}$ the SEC allowed shareholders to disclose information to and communicate with one another regarding proxy issues. This rule change greatly facilitated collective action by large institutional shareholders, and support for shareholder proposals increased throughout the 1990's. ${ }^{176}$ As proposals became a more

\footnotetext{
172 See Del Guerico and Hawkins, supra note _ at 296. Shareholder proposals are regulated by the Securities and Exchange Commission under Rule 14a-8, 17 C.F.R. \$240.14a-8 (2000). This rule requires that companies must bear the cost of including shareholder proposals, but also allows management to omit shareholder proposals on various grounds, including ...

${ }^{173}$ Del Guerico and Hawkins, supra note _ at 296.

${ }^{174}$ Del Guerico and Hawkins, supra note _ at 296.

${ }^{175}$ N. Shahara and A. Hoke-Witherspoon, The Evolution of the 1992 Shareholder Communication Proxy Rules and their Impact on Corporate Governance, 49 Bus. Lawyer 327 (1993).

${ }^{176}$ See Roberta Romano, Less is More: Making Institutional Investor Activism a Valuable Mechanism of Corporate Governance, 18 Yale J. Reg. 174, 178 (2001).
} 
potent threat, large institutional investors were able to successfully negotiate with management for changes in corporate governance without even filing a formal proposal. ${ }^{177}$ Typical corporate governance shareholder proposal topics of the 1990's included requests that shareholder voting be confidential, demands that anti-takeover devices such as poison pills be rescinded, and board of directors issues, such as the request that a majority of the board be made up of independent (outside) directors. ${ }^{178}$ There is a fairly extensive empirical literature finding little effect on financial performance. While there is debate as to why, the most plausible explanation is that the things requested just are not that related to performance. $^{179}$

SR proposals are becoming increasingly common. Popular SR proposals in the past few years have been those (sponsored by labor unions) that would require corporations to disclose their political expenditures, to extend their workplace antidiscrimination policies to cover sexual orientation, and various environmental proposals. ${ }^{180}$ The environmental proposals have tended recently to focus on global warming, asking companies to report and/or reduce their greenhouse gas emissions, to report more generally on how climate change issues are likely to affect their future profitability, or to adopt the GRI reporting guidelines. ${ }^{181}$ As in prior years, the vast majority of these proposals were either withdrawn, or never came to a shareholder vote. ${ }^{182}$ Moreover the SEC's rules on when companies can omit shareholder proposals from their proxy materials has created something of a Scylla and Charybdis effect, as the SEC has allowed companies to exclude some global warming

\footnotetext{
${ }^{177}$ Del Guerico and Hawkins, supra note _ at 297.

${ }^{178}$ For a discussion of the most common type of governance proposals, see Romano, supra note _ at 192208.

${ }^{179}$ Id. [Romano]

180 See Meg Voorhes, 2004 Annual Meeting Season Sets Records, IRRC Corp. Social Issues Reporter 1-5 (April 2004).

${ }^{181}$ Id. [corp social issues reporter, april 2004]

${ }^{182}$ Corp. Social Issues Reporter, April, 2004 at 4.
} 
proposals on the grounds that the proposals asked about risk assessment, an "ordinary business" issue considered outside the scope of shareholder proposals, ${ }^{183}$ while allowing companies to omit many of the proposals calling for enhanced environmental reporting on the ground that the proposals were so vague as to be potentially misleading to shareholders. ${ }^{184}$

Still, the SEC has clearly not been overly hostile to shareholder environmental proposals; SEC staff actually guided activists in revising climate change proposals so that companies could not lawfully omit them. ${ }^{185}$ Moreover, as with corporate governance proposals, the withdrawal of SR shareholder proposals often signals not failure but a successful negotiated agreement with the company. Many proposals asking companies to comply with GRI guidelines in their environmental reports, for example, were withdrawn only after the targeted companies agreed to do so. ${ }^{186}$ There are also cases, admittedly infrequent, where companies have actually agreed to the shareholder proposal. ${ }^{187}$

Inasmuch as the major players in such shareholder activism are large, institutional investors, such activism might seem to contradict my earlier skepticism regarding the existence of institutional investors who truly have SR preferences. Such a contradiction is only superficial. First, as an empirical matter, when SR shareholder proposals have come to

\footnotetext{
${ }^{183}$ Under Rule 14A-8(i)(7), 17 C.F.R. \$240.14a-8(i)(4) (2005). Carolyn Mathiasen, Social Issues Filings Increase for 2004, IRRC Corporate Social Issues Reporter 1, 5 (Jan. 2004).

184 That is, the proposals were omitted under SEC Regulation 14A-8(i)(3), 17 C.F.R. \$240.14a-8(i)(3) (2005). Carolyn Mathiasen, SEC Staff Sanctions Omissions of GRI Proposals, IRRC Corp. Social Issues Reporter 9 (March, 2004).

${ }^{185}$ Mathiasen, Social Issues Filings Increase, supra note _ a t 5. Unsurprisingly, SEC staff were thereafter unsympathetic to corporate attempts to omit the revised proposals, which asked companies to appoint a committee of independent directors to evaluate the company's response to rising public, regulatory and competitive pressure to reduce greenhouse gas emissions. Carolyn Mathiasen and Meg Voorhes, SEC Staff Makes First “No-Action” Decisions, IRRC Corp. Social Issues Reporter 6,7 (Feb. 2004).

${ }^{186}$ Mathiasen, SEC Staff Sanctions Omissions of GRI Proposals, supra note _ at 11; Voohes, 2004 Annual Meeting Season Sets Records, supra note _ at 5.

${ }^{187}$ See, for example, Voorhes, 2004 Annual Meeting Season Sets Records, supra note _ a at 5 (recounting how Tyco International agreed to a shareholder proposal that it report on how it plans to reduce its toxic emissions).
} 
a vote, the vast majority of mutual funds voted against them. ${ }^{188}$ Institutional investors who sponsor such proposals tend either to be mutual funds who are specifically targeted at SR investors, and who therefore may be attempting to credibly signal their own investment policies with such proposals, ${ }^{189}$ or public pension funds such as CalPERS (California Public Employees Retirement System).${ }^{190}$ Other shareholder proposals are made by environmental ngo's, for whom the shareholder proposal is but one aspect of a multifaceted campaign to alter corporate policies. ${ }^{191}$ It is theoretically possible that the market penalties that bad SR companies suffer are so large that even neoclassical institutional investors see a need to protect their investments by making SR shareholder proposals. ${ }^{192}$ The problem with this hypothesis, however, is that on the whole, SR proposals seem to cost a great deal of effort, but to generate very little return in terms of actual changes in corporate behavior. At the most, environmental shareholder proposals have prompted companies either to standardize their reporting or to promise to study and then report on their environmental impacts. ${ }^{193}$ While the standardization of reporting is a good thing (as I argue in more detail below), given the relatively low probability that a shareholder proposal achieves even that much of a

188 Doug Cogan, Most Mutual Funds Opposed All Social Proposals, IRRC Corp. Social Issues Reporter 1-3 (Aug/Sept 2004).

189 Calvert's website, for example, takes pains to publicize its SR shareholder proposal efforts. See Voorhes, 2004 Annual Meeting Season Ends, supra note _ at 5

190 The founding members of the Investor Network on Climate Risk, for instance, were eight state and city treasurers and two labor pension funds. See Doug Cogan, Pension Funds form Investor Network on Climate Risk, IRRC Corp. Social Issues Reporter 10 (Dec. 2003).

191 The Rainforest Action Network's successful attempt to get Citigroup to adopt new lending practices, which involved not only a consumer boycott of Citibank credit cards but also 80 demonstrations in 12 countries, also included a shareholder resolution. Carolyn Mathiasen and Meg Voorhes, Citigroup, RAN Reach Accord on Environmental, IRRC Corp. Social Issues Reporter 17 (Feb. 2004).

${ }^{192}$ As discussed by Gordon L. Clark and Tessa Hebb, Why do they Care? The Market for Corporate Global Responsibility and the Role of Institutional Investors (Working Paper, University of Oxford, School of Geography and Environment, June, 2004).

193 There is a close parallel betweent the SR advocacy of large institutional shareholders such as CalPERS and their corporate governance activity. In the corporate governance area, CalPERS generally only incurs the costs entailed by shareholder advocacy and publicity campaigns when it holds a large block of stock in a particular company; similarly, companies targeted by CalPERS corporate governance reform campaigns do respond, but in ways that (as Romano discusses in more detail) do not necessarily lead to improvements in performance. See generally David A. Skeel, Shaming in Corporate Law, 149 U. Pa. L. Rev. 1811, 1836-1841 (2001). 
change in corporate policy, an activist's return to filing and fighting for such proposals would seem to be not in the outcome of such a conflict, but in the conflict itself. That is, just as companies may wish to signal their own SR performance, so too do activist investors and ngo's need to show their investors and contributors that they are actually committed to the cause of CSR. Shareholder SR proposals are a way to signal such a commitment.

As Roberta Romano has argued in considerable detail, this problem is particularly acute when the institutional investor is a public pension fund controlled not by financial managers but by political appointees. ${ }^{194}$ There is a great risk that what will be in the political self-interest of such appointees may not be in the financial interest of the fund's beneficiaries. In particular, such appointees may well find SR shareholder proposals politically valuable even if they generate no financial return for the public employees' pension funds that they control. More generally, because it costs companies money to consider and (typically) defend against SR shareholder proposals, such proposals represent a transfer of corporate resources from neoclassical shareholders - with no intrinsic concern over the company's SR performance - to activist shareholders. It is indeed precisely for this reason that critics of shareholder proposals such as Romano advocate imposing requirements such as minimum share ownership and cost sharing on SR shareholder proposal advocates.

\section{Legal and Regulatory Implications}

By thinking about the market first, and the law second, the analysis in the preceding two parts of this article has allowed us to revision the law's role in shaping corporate incentives for environmental and social performance. My analysis suggests that from the 
point of view of enhancing, rather than supplanting, market incentives, the most important thing that laws and regulations do may be to help firms commit to credible communication about their environmental performance. That is, on this view, the legal rules that are most crucial in improving CSR are not regulations that try to mandate SR corporate behavior, but rather those determining when and if companies are liable for either failing to or falsely communicating about their social and environmental performance.

In this part, I explore two areas of the law - securities rules governing the obligation of companies to disclose non-financial, social and environmental performance information, and the issue of when false SR claims should be actionable as a form of false advertising that illustrate many of the issues raised in thinking about the role of legal liability in bonding credible corporate communication. I begin, however, by using the federal Superfund law as a paradigm in considering how background legal rules affect the transactional market multiplier. Among other things, this analysis points out the economic importance of a distinction that my earlier analysis elided, that between risk and uncertainty.

A. Lessons from Superfund: Risk, Uncertainty, and the Effects of Extended Liability on the Market Multiplier and Market Existence

As briefly described earlier, the federal Superfund law (more officially, the Comprehensive Environmental Response, Compensation and Liability Act - CERCLA) established liability for the cost of cleaning up certain designated hazardous waste sites. ${ }^{195}$ CERCLA extends strict, joint and several liability to a wide class of actors, including not only those who generated, transported or disposed of hazardous waste, and those who owned

\footnotetext{
${ }^{194}$ Roberta Romano, Public Pension Fund Activism in Corporate Governance Reconsidered, 93 Colum. L. Rev. 795 (1993).

195 CERCLA is codified at 42 U.S.C. $\$ \int 9601-9675$ (2004). In addition to the liability provisions that I focus on here, it also created the Superfund monies that have been available for government-initiated site remediation. For a discussion of Superfund's remediation provisions, and the operation of its remediation program, see
} 
sites at which such waste was disposed, but also current owners of contaminated lands. ${ }^{196}$ Although the original version of Superfund excluded from liability persons holding security interests in land, the exemption was granted only to those holding such interests who did so "without participating in the management" of the property. ${ }^{197}$ Congress did not define the term "without participating in the management," however, and under a number of court decisions, lenders risked CERCLA liability as "owners" or "operators" if they went too far in participating in the management of a property. ${ }^{198}$ Similarly, although Congress set up an affirmative defense for landowners who had exercised due care against all foreseeable third party actions causing hazardous contamination, ${ }^{199}$ the fact that landowners were often in a contractual relationship with the party who had caused the release (such as the real estate seller) made the defense practically unavailable to most landowners.

As of the mid 1980's, CERCLA had created the specter of highly uncertain, near absolute liability for having anything to do with a contaminated piece of real estate, liability that ranged into the tens of millions of dollars for some sites, but which had no known upper bound and was practically extremely unpredictable. The Superfund liability system was not without a rationale, indeed a rationale that my earlier analysis suggests was a good one. By extending strict, joint and several liability over the whole chain of hazardous waste management - from the original generator of the waste, to the disposer, the owner of the (land) disposal site, and even subsequent owners -- Superfund made it impossible for large companies who generate hazardous waste to eliminate their potential liability for its

Robert V. Percival, Christopher H. Schroeder, Alan S. Miller and James P. Leape, Environmental Regulation: Law, Science and Policy 284-288 (4th ed. 2003).

196 See CERCLA Section 110.

197 See 42 U.S.C. $\$ 9601(20)(A)$.

198 Most famously, in U.S. v. Fleet Factors, 901 F.2d 1550 (11 th Cir. 1990), cert. denied, 111 S.Ct. 752 (1991), where the court ruled that a secured lender could be found to have participated in management if it had the capacity to influence the borrower's treatment of hazardous waste.

19942 U.S.C. $\$ 9607(b)(3)$. 
mismanagement by outsourcing disposal to small, judgment proof companies. Evidence suggests that Superfund's extended joint and several liability scheme has had a profound effect in changing how companies manage their hazardous waste, with the largest firms now internalizing all aspects of hazardous waste management, and facing a much stronger incentive to minimize the amount of hazardous waste that they generate.

At the same time, especially up until 1990 or so, the magnitude of potential Superfund liability was so uncertain that the law effectively destroyed the market for contaminated lands. The key to understanding Superfund's chilling effect on the contaminated land market is the distinction between risk and uncertainty. My earlier analysis of the market multiplier presumed that environmental regulatory exposure can be thought of as a kind of risk that markets price into transactions. While risks can indeed be priced, uncertainty cannot. The distinction between risk and uncertainty is between environmental liabilities with known probabilities and potential magnitudes (environmental risk) and environmental liabilities with unknown probabilities or magnitudes (uncertainty) ${ }^{200}$ Environmental risks can be priced. If, for instance, a potential buyer and seller agree that it may cost somewhere between $\$ 5$ and $\$ 10$ million to clean up a Superfund site, and share the perception that all values within this range are equally likely, then they can agree that the expected Superfund cleanup cost will be $\$ 7.5$ million. As between risk neutral parties, this is the amount that the party assuming the cleanup risk would demand to assume that risk. By contrast, environmental uncertainties cannot be priced. If, for instance, the buyer and seller know that regulators may require costly site cleanup, but don't know what the range of potential cleanup costs might be, or have any particular guess as to the probability of different cleanup

\footnotetext{
200 The terminological distinction between "risk" and "uncertainty" has a long lineage in economics, going back at least to John Maynard Keynes, A Treatise on Probability (1921) and Frank Knight, Risks, Uncertainty and Profit (1921).
} 
cost realizations, then they cannot form an expected cleanup cost and cannot price this into a transaction.

Because environmental uncertainties cannot be priced into transactions, they will often prevent transactions from occurring at all unless they are resolved. In other words, because the parties cannot allocate environmental uncertainties by price, they allocate them in direct, non-price ways, by taking actions to remedy the environmental problem. Sometimes, however, environmental uncertainty is so severe that it completely destroys the potential supply of capital for a transaction. When it is environmental risk that causes this availability effect, it is relatively straightforward to see how the effect is a direct consequence of the risk-return tradeoff that lies at heart of business finance. Buying a business or a piece of real estate is an investment. Given the great diversity of available investment opportunities, if the potential environmental liabilities involved in purchasing assets such as an abandoned industrial site or small chemical company are huge, then the potential returns from such an investment will have to be correspondingly large for a rational, risk averse buyer to choose to make that purchase. When the potential downside dwarfs the potential upside to a deal, no investor interested in a positive expected return will touch it. In transactions involving environmental risk, it is the magnitude of the risk in relation to potential upside return that determines whether the deal is market-worthy.

True environmental uncertainty is even more likely to be a transactional death knell. Because environmental uncertainties cannot, by definition, be measured, they cannot be analyzed in the conventional risk-return framework. If they are small, then such uncertainties can be safely ignored. But when they are large, and potentially open-ended, environmental uncertainty in this "hard" sense raises the specter of potentially catastrophic 
loss. The inability to safely bound its potential loss to rule out such catastrophic loss may cause even the largest, and otherwise risk neutral firm to avoid investments that risk such loss. This is one of the lessons of the modern (and still developing) economic theory of credit risk pricing and measurement. ${ }^{201}$ This body of work teaches us that even for a risk neutral firm, the cost of risk is likely to be supra-linear for high realizations of risk: that is, it is more than proportionately costly for a firm to cover a really large loss than to cover a small loss. There are a variety of reasons why this will be true. When a loss is so large that it wipes out the equity value of the firm, then the firm will have to be liquidated or reorganized. For large losses that are not so great as to completely wipe out equity, covering such a large loss will nonetheless typically mean selling relatively illiquid assets, perhaps getting only highly discounted "fire sale" prices. In these and many similar cases, transaction costs magnify quickly when such "crisis" states are reached. From a functional point of view, a "catastrophic" loss is any loss greater than that level at which the firm's cost of risk becomes supra-linear. When environmental uncertainty extends to encompass such catastrophic levels of loss, even rational risk neutral market actors will eschew transactions that carry such uncertainty with them.

For policy purposes, the important lesson is that whether environmental liabilities generate risk or uncertainty is a function largely of the legal system in which such liabilities are determined. It seems clear that until at least the late 1980's, Superfund was perceived as imposing high levels of uncertainty about potential liability for the costs of cleaning up hazardous waste sites. With strict, joint and several and retroactive liability covering everybody from hazardous waste generators to land purchasers, and no boundaries on the outer limits of liability, Superfund had a chilling effect on business transactions involving

\footnotetext{
${ }^{201}$ See Darrell Duffie and Kenneth J. Singleton, Credit Risk: Pricing, Measurement and Management (2003).
} 
any business or site that anything to do with hazardous waste. ${ }^{202}$ Beginning in the 1980 's, however, and continuing into the 1990's, Superfund liability was transformed from a regime of unbounded uncertainty to one of estimable risk. One set of changes occurring during this period was a series of Congressional amendments that created a fault-based safe harbor for new purchasers (and their lenders) of contaminated lands. In 1986, Congress created what is known as the innocent purchaser defense, immunizing from Superfund remediation costs those purchasers of contaminated lands who "have undertaken at the time of acquisition, all appropriate inquiry into the previous ownership and uses of the property consistent with good commercial or customary practice in an effort to minimize liability." ${ }^{203}$ In 1996, Congress overrode court decisions by specifying that secured lenders could incur Superfund “owner” or "operator" liability only by actually participating in the management of a contaminated property (rather than merely having the capacity to influence such management). ${ }^{204}$ Most recently, in the 2002 Small Business and Brownfields Revitalization Act, Congress required that EPA promulgate regulations specifying what sort of site investigation constitutes the "all appropriate inquiry" that will immunize landowners and prospective purchasers from potential Superfund liability. ${ }^{205}$

These statutory changes have both aided in and reflected the transformation of liability for hazardous waste cleanup from a regime of unbounded, deal-killing uncertainty to one of estimable risk. The 1986 innocent purchaser amendment created at best a very blurry safe harbor, with court decisions making it a very difficult defense to satisfy. ${ }^{206}$ The effect of

\footnotetext{
202 [add citations]

20342 U.S.C. $\int 9601$ (35)(B).

204 Asset Conservation, Lender Liability and Deposit Insurance Protection Act of 1996, PL No. 104-208.

205 This portion of the 2002 Brownfields Act is codified at 42 U.S.C. \$9601(35)(B)(iii).

206 See, e.g., United States v. A\&N Cleaners \& Launderers Inc., 854 F. Supp. 229 (S.D. N.Y. 1994) (requiring landowner to inquire as to disposal practices of business previously operating on property), United States v.
} 
these was to create a significant probability that real estate purchasers would assume Superfund liability for contamination caused under prior ownership. As my model predicts, buyers responded to this potential liability by demanding pre-acquisition site investigation and overall environmental due diligence. This demand evolved from the highly firm-specific standards of the 1980's to the promulgation in 1993 of formal, ASTM-certified professional standards for site assessment and transaction screening. ${ }^{207}$ These standards were a market response to a legal regime of uncertain liability assumption, precisely the sort of response that my model predicts. After the adoption of these standards, the market in contaminated properties was rejuvenated. ${ }^{208}$ It was market demand, not legal reform, which crystallized the uncertain Superfund liability regime into one of estimable, priceable risk. ${ }^{209}$

B. The Rage for Transparency: The Relative Ineffectiveness of Voluntary Disclosure, and How Mandatory Disclosure May Help

1. Environmental Disclosure Requirements under the Federal Securities Laws

Broderick Investment Co., 862 F. Supp. 272 (D. Colo. 1994) (actual knowledge that lessor discharged waste on the property vitiated defense).

207 On the history of this process, culminating in what are known as ASTM 1527-93 (Phase I site assessments) and ASTM 1528-93 (transaction screens), see Dianne P. Crocker et. al., Conflict-Compomise-Consensus: The Embroiled History of the ASTM ESA Standard, 7 Envl. Site Assessment Report 1 (July 2002).

208 As evidenced by a dramatic increase in the number of Phase I site assessments, from roughly 150,000 in 1994 to over 260,000 in 1998. See Environmental Site Assessment State of the Industry Report for 1998, 4 Environmental Site Assessment Report 1, 2 (Feb. 1999) and Environmental Site Assessment State of the Industry Report, 3 Envl. Site Assessment Report 1, 5 (Feb. 1998). For judicial recognition that by 1995, ASTM E1527-93 was the recognized standard for determining whether a purchaser had undertaken "all appropriate inquiry,” see XDP, Inc. v. Watumull Properties Corp., 2004 WL 1103023 (D. Ore. May 14, 2004). ${ }^{209}$ Indeed, under the 2002 Brownfields Reform Act, until such time as the EPA promulgates the required regulatory definitions, ASTM 1527-97 (the 1997 revision of the original 1993 Phase I site assessment standard) satisfies the statutory "all appropriate inquiry" requirement for the innocent purchaser/bona fide prospective purchaser defense. See 42 U.S.C. $\int 9601(35)(B)(i v)(I I)$. 
American public securities markets are often held up as an international model of how legal requirements for accurate, transparent financial disclosure in corporate reports can facilitate market efficiency. ${ }^{210}$ Even in the post-Enron environment, however, federal securities laws generally require corporations to disclose only certain types of financial data pertaining to operating results and capital structure and do not require the disclosure of general information pertaining to a company's environmental performance. ${ }^{211}$ More precisely, three "Items" under regulation S-K -- which catalogues specific disclosure requirements under all federal securities laws and regulations - may apply to require the disclosure of a corporation's environmental performance: 1) Item 101, which requires a description of the reporting company's business; 2) Item 103, requiring disclosure of legal proceedings; and, 3) Item 303, which requires a management discussion and analysis which must disclose "known future uncertainties and trends" that may materially affect financial performance. ${ }^{212}$ In actual application, whether any of these items require the disclosure of particular aspects of a firm's environmental performance depends upon whether those aspects surpass either a general materiality threshold defined by reference to whether the

\footnotetext{
${ }^{210}$ See Louis Lowenstein, Financial Transparency and Corporate Governance: You Manage what You Measure, 96 Columbia L. Rev. 1335, 1340-41 (1996)("More than any other nation, we have cast a broad vote of confidence in the integrity and efficiency of the markets, and in the transparency not just of the markets but of the underlying companies.") For an empirical study of the relative efficiency of American securities markets, see [cite Guzman etc.], and for more general discussions of how global capital market integration impacts upon the optimal design of U.S. securities regulation, see, e.g., Merritt B. Fox, Securities Disclosure in a Globalizing Market: Who Should Regulate Whom, 95 Mich. L. Rev. 2498 (1997) and James D. Cox, Rethinking U.S. Securities Laws in the Shadow of International Regulatory Competition, 55 Law \& Contemp. Probs. 157 (1992).

${ }^{211}$ See the brief summary of disclosure requirements provided by Williams, supra note _, 112 Harv. L. Rev. 1197, 1206-1209 (1999). On the effect of Sarbanes-Oaxley in altering and enhancing disclosure requirements see Philip E. Karmel, SEC Disclosure Requirements for Environmental Liabilities and the Impact of the Sarbanes-Oxley Act, 511 PLI/Real 473 (Nov. 2004).

${ }^{212}$ See Perry W. Wallace, Disclosure of Environmental Liabilities Under Securities Laws: The Potential of Securities-Market-Based Incentives for Pollution Control, 50 Wash. \& Lee L. Rev. 1093 (1995); Elizabeth Geltman, Disclosure of Contingent Environmental Liabilities by Public Companies Under the Federal Securities Laws, 16 Harv. Envtl. L. Rev. 129 (1992).
} 
"reasonable" investor would consider the information relevant in making her investment decision, or a specific threshold that may be as high as $10 \%$ of firm market value. ${ }^{213}$

These requirements have been further clarified by SEC Staff Accounting Bulletins and by various rules and interpretations issued by the Financial Accounting Standards Board (FASB). In 1993, the SEC issued Staff Accounting Bulletin No. 92 (“SAB 92”), whose question and answer format is perhaps most notable for clarifying that when a company doesn't think any particular loss realization within its range of potential losses is any more likely than any other within the range, then it may disclose the minimum loss estimate (lower bound) within the range. Perhaps the most concrete guidance, however, has been provided by Statement of Position 96-1 issued by the Association of Certified Public Accountants (which applies to disclosure of Superfund-type remediation liabilities) (14 $^{214}$ and FASB Statement of Financial Accounting Standards No. 5 (which sets out a general standard for the recognition of contingent liabilities in financial statements). Under these two guidance documents, a company's obligation to disclose contingent environmental liabilities turns on whether the liability is "probable" and "reasonably estimable," in which case the company is required to recognize its estimated liability, but may disclose either a range of values, or the most likely or expected value within that range. ${ }^{215}$

Thus the federal securities laws clearly require that companies disclose some kinds of information about environmental performance, such as material information about pending

\footnotetext{
${ }^{213}$ Williams, supra note _ at 1208. See also Levine v. NL Industries, Inc., 717 F.Supp. 252 (S.D. N.Y. 1989), affd, 926 F.2d 199 (2d Cir. 1991) (holding that firm was not required to disclose in its Form 10-K various emission standards violations at one of its facilities, because the government, not the firm, was potentially liable for those violations under an indemnity provision, and the facility accounted for at most .2\% of the company's annual gross income, and hence the information was not material).

${ }^{214}$ See Herbert S. Wander, Securities Law Disclosure After Sarbanes-Oxley, SJ 014 ALA-ABA 547, 801-804 (2003).

${ }^{215}$ See Philip E. Karmel, SEC Disclosure Requirements for Environmental Liabilities and the Impact of the Sarbanes-Oxley Act, 511 PLI/Real 473, 480-481 (November, 2004). See also Williams, supra note _ at 12081209.
} 
lawsuits and "probable" and "estimable" future liability. ${ }^{216}$ On the other hand, it is equally clear that American securities laws generally do not require publicly traded companies to disclose general information regarding things such as product safety, environmental performance, labor practices and supplier/vendor standards. ${ }^{217}$ Whether such "social disclosure" was required by the securities laws was intensely debated during the 1970's, when the Natural Resources Defense Council (NRDC) attempted to persuade the SEC that information regarding corporate social performance had at the very least to be disclosed in proxy materials regulated by Section 14(a) of the Securities Exchange Act of $1934 .{ }^{218}$ By the early 1980's, the SEC had established a relatively narrow disclosure requirement for proxy contest materials, mandating the disclosure of economically material information whose "central purpose" was neither to influence "corporate conduct" nor to "promote social goals unrelated" to the federal securities laws need not be disclosed. ${ }^{219}$

As argued by Williams, ${ }^{220}$ with only two "ethical investor" funds holding a grand total of only $\$ 19$ million in funds even existence in the late 1970's, the SEC may well have been correct that as of that time, corporate social performance was simply not relevant to the typical "reasonable" investor, and therefore not economically material. However, as recounted earlier, the growth of such funds has been astronomical. Their growth has been accompanied by the recent release of highly publicized studies indicating that firms in certain

\footnotetext{
${ }^{216}$ See Williams, supra note _ at 1208-1209.

${ }^{217}$ See Williams, supra note _ at 1201-1202.

${ }^{218}$ Williams, supra note _ at 1235-1263.

${ }^{219}$ Williams, supra note _ at 1264 (citing Commission Conclusions and Rule Making Proposals, Securities Act Release No. 5627, Exchange Act Release No. 11733 [1975-76 Tansfer Binder] Fed. Sec. L. Rep. (CCH) 80,310 at 85,705 (Oct. 14, 1975)).

${ }^{220}$ Williams, supra note _ at 1267.
} 
environmentally sensitive sectors - such as the pulp and paper and electric utility industries are not adequately disclosing financially material environmental liability exposures. ${ }^{221}$

With renewed investor interest in corporate environmental performance, and data showing that existing environmental disclosure is not even meeting current regulatory requirements, ${ }^{222}$ twenty six non-profit foundations recently petitioned the SEC to adopt tougher new mandates for the corporate disclosure of environmental liabilities. ${ }^{223}$ In the summer of 2004, the General Accounting Office (GAO) published results of a survey of expert opinions on the state of corporate environmental disclosure. The main finding of the survey was that it was very difficult to determine just how much companies were disclosing. Rather than recommending major changes in SEC disclosure rules, the GAO report called instead for increased effort by the SEC to systematically collect and analyze data on corporate environmental reporting (and to make such data publicly available through a searchable electronic database) and for more data sharing between the SEC and the EPA. ${ }^{24}$

The Sarbanes-Oxley Act of 2002 may well have given advocates of enhanced environmental disclosure what they have demanded for so long. Sarbanes-Oxley requires corporate CEO's and CFO's to certify that their companies' financial statements "fairly present in all material respects the financial condition and results of the issuer," and also requires the disclosure within four days of any "additional information concerning material

\footnotetext{
${ }^{221}$ See Robert Repetto and Duncan Austin, Coming Clean: Corporate Disclosure of Financially Significant Environmental Risks (WRI, 2000); Robert Repetto and James Henderson, Environmental Exposures in the U.S. Electric Utility Industry (2002).

${ }^{222}$ For a succinct summary of the results of various studies, all of which have found low compliance rates with various reporting guidelines, see David W. Case, Corporate Environmental Reporting as Informational Regulation: A Law and Economics Perspective, 76 U. Colo. L. Rev. 379, 410 (2005).

${ }^{223}$ See SEC Urged to Enforce Rule to Require Disclosure of Environmental Liabilities, 71 ELR 2180-2181 (August, 2002); Revised Petition, SEC File No. 4-463. For the general position of the lead petitioner, the Rose Foundation, see Susannah Blake Goodman, Jonas Kron, Tim Little, The Environmental Fiduciary: The Case for Incorporating Environmental Factors into Investment Management Policies (Rose Foundation, 2001?). ${ }^{224}$ GAO, Environmental Disclosure: SEC Should Explore Ways to Improve Tracking and Transparency of Information 36-37 (GAO-04-808, July 2004).
} 
changes in the financial condition....which may include trend and qualitative information."225 In addition to this public certification requirement, Sarbanes-Oxley has an internal reporting requirement that applies to attorneys. SEC regulations promulgated under Section 307 of Sarbanes-Oxley require corporate (and some outside) attorneys who become aware of evidence that of a "material violation" of the law by the corporation to report that evidence to the corporation's chief legal or chief executive officer. ${ }^{226}$ The SEC failed to provide any examples of what might constitute such a report-triggering "material violation," leaving corporate environmental practitioners to wonder when an environmental liability or compliance issue might constitute such a violation. ${ }^{227}$ Still, the key thing about SarbanesOxley is that both its certification and internal reporting requirements hinge upon “materiality." Just as "material violations" must be internally reported, so too must financial statements "fairly present" the financial condition of the company "in all material respects." These requirements clearly extend beyond those imposed by Generally Accepted Accounting Principles (GAAP). For this reason, a number of environmental consultants have interpreted Sarbanes-Oxley as requiring enhanced disclosure of environmental liabilities, both within the internal corporate hierarchy and to the public, relative to existing SEC disclosure requirements. ${ }^{228}$

2. Evaluating Environmental Disclosure Requirements

\footnotetext{
225 Sarbanes Oxley Sections 302(3) and 409(1) [add complete cite]

${ }^{226}$ More precisely, 17 C.F.R. \$205.2(i) defines "material violation" as "material violation of an applicable United States or federal securities law....or a similar material violation of any United States federal or state law."

227 See Karmel, supra note _ at 509-510.

228 See, e.g., Sarbanes-Oxley Act: Environmental Risk moves from the Back Room to the Boardroom, 9 ESA Report 1 (August, 2004).
} 
My earlier analysis concluded that even though top managers of publicly held want to avoid surprising the market with unanticipated bad news about environmental liabilities or compliance costs, they will generally be unable to credibly commit to disclosing such bad news voluntarily unless there is a significant risk that regulators or will eventually compel them to reveal the information publicly. This analysis provides a general case for some form of mandatory disclosure of environmental liabilities and costs. The real question is what sort of disclosure should be mandated.

The answer to this question rests upon a basic fact about environmental performance data: that while environmental (more generally regulatory) requirements have financial consequences, those consequences are indirect. Unlike both past operating results or future market contingencies that effect operating profits (or losses), environmental "results" are not market results, but non-market factors that effect financial results. While there are longestablished conventions for how to account for various market factors that effect financial performance, there are no established accounting conventions governing the measurement of environmental performance, nor, even more importantly, for the recognition of the financial consequences of alternative environmental management decisions. ${ }^{229}$ While it may be clear, for example, how to account for the $\$ 50$ million that a company spends today on pollution prevention, the dollar value of that expenditure will be in saved fines (and future compliance expenditures) and enhanced regulatory and/or community good will, none of which may be estimable with a sufficient degree of precision to effect the company's financial accounts.

\footnotetext{
${ }^{229}$ As put by Waymond Rodgers and Thomas J. Housel, The Effects of Environmental Risk Information on Auditors' Decisions about Prospective Financial Statements, 13 European Acct. Rev. 523, 524 (2004), "auditors' perceptions of non-traditional information are not well calibrated due to a lack of benchmarks." See also A.Y. Ilinitch, N.S. Soderstrom and T.E. Thomas, Measuring Corporate Environmental Performance, 17 J. Accting. Public Pol. 383 (1998); Mitchell et. al., Voluntary Environmental Reporting Practices, supra note
} 
For this reason, the SEC's basic disclosure standard, that costs be "probable" and "reasonably estimable" makes good sense as tracking the de facto limits of current accounting practice. On the other hand, the SEC's almost complete failure to enforce the regulatory requirements applying to environmental disclosure ${ }^{230}$ has created a situation in which companies cannot credibly commit to such disclosure. For recall that on my analysis it is only the threat of external discovery that will motivate a company to abide by its own stated policy of voluntarily disclosing non-misleading bad environmental news. With no threat of SEC enforcement, managers of public companies have an incentive not to reveal bad environmental news, but to conceal it. Among the primary strategies for concealment include the revelation only of lower bounds of potential costs, incomplete discussion of the assumptions behind those lower bounds and the range of potential costs that they bound, and the failure to aggregate liabilities that stem from a common corporate policy but from independent regulatory or common law actions. Egregious examples of each of these should be easy to enforce against, especially now that Sarbanes-Oxley is at hand, and such enforcement would go a long way toward making it possible for companies to credibly commit to effective voluntary disclosure.

C. Regulation by Common Law: Will Liability for False CSR Communications Lead to More Informative CSR Talk?

When several years ago the Court granted certiorari to hear Kasky v. Nike, Inc. (hereafter referred to as Nike-Kasky), ${ }^{231}$ many observers viewed the case as likely to generate a landmark ruling clarifying the application of the First Amendment's free speech guarantees

230 Between 1975 and 2000, only 3 of 5,000 SEC enforcement actions were based on insufficient reporting of material environmental information. Robert Repetto and Duncan Austin, Coming Clean, supra note _ at 1112.

23127 Cal. $4^{\text {th }} 939,45$ P.3d 243, 119 Cal. Rptr. 2d 296 (2002). 
to commercial speech. ${ }^{232}$ Instead, the Court dismissed certiorari as improvidently granted, ${ }^{233}$ and the case settled shortly thereafter, with Nike agreeing to pay $\$ 1.5$ to a Washington, D.C. non-governmental labor standards organization. ${ }^{234}$ Even without a Supreme Court ruling, Nike-Kasky raises important issues regarding the proper role for legal liability in disciplining false corporate SR communications. Indeed, by applying my analysis of economic incentives for CSR communication to the Nike case, we are better able to understand both the case for and against legal liability for false CSR speech.

1. Evaluating the Arguments in Nike v. Kasky

The plaintiff in Nike-Kasky was acting as a private attorney general seeking to enforce California's unfair competition and false advertising laws against Nike. Kasky alleged that Nike had violated those laws by making at least nine false and fraudulent communications ranging from press releases, letters to newspapers and a letter to university presidents and athletic directors - regarding the labor practices of its subcontractors in China, Vietnam and Indonesia. In these communications, Nike allegedly asserted that workers in these countries who made Nike products were not abused physically or sexually, were not paid illegally low wages or forced to work illegally long hours, but rather received wages that were on average twice the local norm as well as free meals and health care. ${ }^{235}$ Kasky sought restitution from Nike of any financial gain it had realized from the false and misleading communications, and also an injunction requiring Nike to cease misrepresenting its working conditions in Asia.

\footnotetext{
${ }^{232}$ Introducing an entire law review symposium issue devoted to the Nike v. Kasky case, Ronald K.L. Collins and David M. Skover, Foreward: The Landmark Case that Wasn't: the Nike v. Kasky Story, 54 Case Western Res. L. Rev. 965, 966 (2004) well describe the buzz surrounding the case: "a bevy or renowned lawyers, thousands of pages of briefs, extended time for oral arguments, incessant hype, almost unprecedented editorial buzz, and endless pundit predictions..."

233123 S. Ct. 2554 (2003).

234 Adam Liptak, Nike Move Ends Case over Firms’ Free Speech, New York Times, A8, September 13, 2003.

235 These are the plaintiff's factual allegations as recounted by the California Supreme Court at 119 Cal.Rptr.2d 296, 301-302.
} 
Nike moved for dismissal of the complaint on the grounds that the First Amendment to the United States constitution absolutely barred the relief requested by Kasky.

The lower courts in California agreed with Nike. Both the trial and appellate courts recognized that under the Supreme Court's First Amendment doctrine, commercial speech does not receive as much protection as does noncommercial speech, ${ }^{236}$ but they held that Nike's statements were noncommercial speech. Under the Court's First Amendment cases, the commercial versus non-commercial classification makes an enormous difference, because while content-based regulations of noncommercial speech are constitutional only if they are found to be the least restrictive means of promoting a compelling government interest, ${ }^{237}$ false or misleading commercial speech is not entitled to First Amendment protection, ${ }^{238}$ and even truthful commercial speech may be regulated provided that there is a "reasonable fit" between regulatory means and ends. ${ }^{239}$ Viewed as noncommercial speech, Nike's communications were clearly constitutionally insulated from sanction under California's unfair competition and false advertising laws.

The California Supreme Court took a different view, concluding that when a business such as Nike sends communications to actual and potential purchasers of its product that make factual representations about its own business practices, then it is engaging in commercial speech. ${ }^{240}$ Because the First Amendment does not protect misleading commercial speech, the California Supreme Court reinstated and remanded Kasky's action.

\footnotetext{
236 See Bolger v. Youngs Drug Products Corp., 463 U.S. 60, 64-65 (1983), discussed at 119 Cal.Rptr.2d 296, 304-305.

${ }^{237}$ United States v. Playboy Entertainment Group, Inc., 529 U.S. 803, 813 (2000).

${ }^{238}$ Edenfield v. Fane, 507 U.S. 761, 768 (1993) ("the State may ban commercial expression that is fraudulent or deceptive without further justification.”)

${ }^{239}$ Board of Trustees, State Univ. of N.Y. v. Fox, 492 U.S. 469, 480 (1989).

240119 Cal.Rptr.2d 296, 313-314.
} 
By looking to the type of speaker, intended audience and message content to determine whether or not a particular message is commercial or noncommercial speech for First Amendment purposes, the California Supreme Court attempted to fashion a legal test designed specifically to determine whether speech is commercial in the particular sense that it may be regulated by state false advertising laws. ${ }^{241}$ The California high court justified its test by referring back to the three reasons given by the Supreme Court for leaving misleading commercial speech unprotected by the First Amendment: 1) the relative ease with which a commercial speaker, who possesses asymmetric information about his own product or service, may verify the truthfulness of his statements about that product or service; 2) the general "hardiness" of commercial speech - that is, the low probability that profit-motivated advertising type speech will be chilled by regulation; and, 3) the government's general authority to regulate to prevent commercial harms. ${ }^{242}$ Whether the Kasky majority's threepart test for determining when the First Amendment protects speech from a state false advertising effectively implements this rationale is a question that will undoubtedly be discussed at length by First Amendment commentators. The dispute between the majority and dissenting justices on the California Supreme Court, however, centered not so much around this question as around the application of the three part test, and in particular its third prong, message content. The majority noted that all of the Court's commercial speech cases have involved speech that referred to the product or service for sale, and argued that a broad interpretation of such references to include statements about the more general business operations and methods of a company was completely consistent with the Court's

\footnotetext{
${ }^{241} 119$ Cal.Rptr.2d 296, 311.

242119 Cal. Rptr. 296, 308.
} 
reasons for leaving misleading commercial speech constitutionally unprotected. ${ }^{243}$ For the dissent, the fact that Nike's communications concerned statements pertaining not only to conditions at its own subcontractors' factories but also to more general public policy issues such as whether multinational companies such as Nike have an obligation to export health, safety and environmental standards to lesser developed countries where they have facilities meant that Nike's communications "inextricably intertwined” commercial and noncommercial speech and hence were protected by the First Amendment. ${ }^{244}$

After the California Supreme Court reversed the decisions below, Nike successfully sought certiorari before the Supreme Court. The Court initially granted the requested writ, but in Nike, Inc. v. Kasky, by a 6-3 vote, the Supreme Court dismissed the writ of certiorari as improvidently granted. ${ }^{245}$ Six Justices either concurred or dissented from the dismissal of certiorari. The concurring and dissenting opinions (by Justices Stevens and Breyer, respectively) reveal that these six Justices agreed that the allegedly false statements by Nike were contained in communications by the firm that not only were intended to reach customers and hence generate sales, but which also were "part of an ongoing debate about important public policy issues that was concerned not only with Nike's labor practices, but with similar practices used by other multinational corporations. ${ }^{246}$ The difference between the concurring and dissenting Justices was that the concurring members did not feel that the question of whether First Amendment protections should extend to such mixed corporate speech should be decided without a more complete factual record below. In his dissent (joined by Justice O'Conner), Justice Breyer argued that there was nothing to prevent the

\footnotetext{
243119 Cal. Rptr. 296, 311-313, 314-317

244119 Cal. Rptr. 296, 322-325.

245123 S. Ct. 2554 (June 26, 2003).

246123 S.Ct. 2554, 2559.
} 
Court from deciding the question, and that indeed it should have done so, given that reversal of the California Supreme Court's decision was a "very realistic possibility."247

Justice Breyer's discussion of why the Court would likely have reversed the California courts and found Nike's speech protected by the First Amendment presents a perfect foil for the analysis developed in Part I of this essay. According to Justice Breyer, while communications such as a "dolphin-safe tuna" product label would clearly be "commercial speech," Nike's assertions regarding its labor practices were very different. First of all, they were not made in a "traditional advertising or labeling" context, but appeared rather in letters - to university presidents and athletic directors, and various newspapers. ${ }^{248}$ Unlike product labels or advertisements, such letters did not, according to Justice Breyer, "propose the presentation or sale of a product or any other commercial transaction." ${ }^{249}$ On Justice Breyer's characterization, Nike's letter (his opinion focuses on the letter to university presidents and athletic directors, which he assumes presents the best case for "commercial speech" among the nine messages at issue) purported to convey information to a wide audience of persons with an interest in Nike's labor practices, and to contribute to an ongoing public debate - "in which participants advocated, or opposed, public collective action" - regarding Nike's labor practices. ${ }^{250}$ Hence even though California's false advertising law generally furthered a "legitimate, traditional and important" state interest in an "honest commercial marketplace,"251 its enforcement by private plaintiffs allowed a "large and hostile crowd freely able to bring prosecutions designed to vindicate their beliefs [that a company was not telling the truth], and to do so unencumbered by the legal and practical checks that

247123 S.Ct. $2554,2564$.

248123 S.Ct. 2554, 2565.

249123 S.Ct. 2554, 2565.

250123 S.Ct. 2554, 2565.

251123 S.Ct. 2554, 2565. 
tend to keep the energies of public enforcement agencies focused on more purely economic harm. ${ }^{, 252}$ Because California’s false advertising law requires only a finding of negligent falsity for potential liability to attach, a company could be liable under that statute for making absolute and unqualified claims about its working conditions whenever a judge or jury finds that the company knew or should have known that there were enough exceptions to its claims to warrant their qualification. ${ }^{253}$ Even more immediately, Justice Breyer argued, allowing the present case to proceed would create a fear of potential lawsuits and liability that would likely have a significant effect in deterring companies doing business in California from participating in public debate. ${ }^{254}$ Indeed, as proof that such concern was not "purely theoretical," Justice Breyer adduced Nike's uncontradicted assertion to the Court that because of Kasky's lawsuit, it had already begun to restrict "severely" all of its communications on social issues that could reach "California consumers," refused "dozens of invitations...to speak on corporate responsibility issues," delayed release of its annual Corporate Social Responsibility Report, and even decided against attempting to get its stock listed on the Dow Jones Sustainability Index (an index that is widely used by "green" mutual funds in assembling their portfolios). ${ }^{255}$

Justice Breyer's dissent rests upon two types of arguments. The first, that Nike's letters were not traditional advertising but rather contributions to an ongoing "public debate" about its labor practices, would have the result in the case turn on an anachronistic formalist distinction. It was not the desire to participate in a public debate that motivated Nike's letter writing campaign, but rather the desire to preserve very lucrative sales relationships with University athletic departments and other socially conscious consumers

252 123 S.Ct. 2554, 2565.
253 123 S.C. 2554, 2567.
254123 S.Ct. 2554, 2567. 
who were considering not buying Nike products because of Nike's labor practices. In the new world of socially responsible consumers, how a company makes its product is as important to the consumer as are more conventional attributes of the product itself. In this world, Nike's letters did indeed "propose the presentation or sale of a product or any other commercial transaction. ${ }^{256}$ Breyer's attempt to distinguish Nike’s letters from traditional product advertising ignores that the consumer marketplace has changed in ways that make those letters directly relevant to SR consumers' buying decisions.

Justice Breyer's second and stronger argument was that highly uncertain liability for false advertising liability might chill informative corporate speech about issues of general public concern. This argument invokes a traditional, core defense of liability-free speech. This defense holds that the proper response to a speaker's false assertions about important public policy matters is not potential civil liability for false speech, but rather responsive public speech revealing and correcting the untruths of the speaker's utterances. Rather than relying upon juries to assess the truth or falsity of speech in ex post civil litigation, we should rely upon informed advocates competing in the marketplace of ideas to find and reveal false speech. Rather than punishing corporations with negligence-based civil liability, we should allow consumers to punish them by taking their business elsewhere when they learn that the corporation has lied about its environmental or labor practices.

As applied to most speech regarding public policy issues, the marketplace of ideas model is highly persuasive. For most public policy issues, it is hard to see what is gained in terms of the amount of information made available to the actual consumer market or investor market - by allowing liability for false assertions about such issues. When the dispute centers around an issue of public policy - whether, for example, Congress should

${ }^{255} 123$ S.Ct. $2554,2568$. 
regulate the foreign labor practices of American multinationals by passing something like a fair labor standards version of the Foreign Corrupt Practices Act - most or all of the information relevant to that debate is in the public domain, equally accessible to both sides. Advocates of such public legislation do not need access to discovery apparatus provided by the civil liability system in order to make their case. Such liability thus generates costs - the potential for reduced corporate speech opposing the legislation - without any clear benefits.

In the Nike case, by contrast, the dispute was not over a general issue of public policy - what Congress or an agency should or should not do - but rather was over the actual labor practices of one specific company. Outside the context of a civil lawsuit, and without the tool of civil discovery, an advocate such as Kasky would have faced an extremely limited ability to gain information about what Nike's labor practices actually were. Unlike a product, which can be purchased and reverse engineered to determine its content, the process by which a company makes its product cannot be publicly observed without the company's consent. In the absence of such consent, the civil discovery process may be the only way for the agents of SR activists to gain knowledge of whether the company's assertions are true or false.

Another and perhaps even sharper way to see the clear dissimilarity between firmspecific versus general public policy issues is to remember that Nike might well have taken the legal offensive against Kasky, suing him for commercial defamation. Such counteroffensive commercial defamation suits have become commonplace in American disputes over the siting of landfills and other locally objectionable industrial facilities, ${ }^{257}$ and have achieved a certain infamy in Europe, where McDonald's pursued a fifteen-year long commercial defamation action against two London activists who attacked the company's

${ }^{256} 123$ S.Ct. 2554, 2565. 
production and labor practices, an action that concluded with the longest civil trial in English legal history. ${ }^{258}$ The basis for a commercial defamation action is that the plaintiff company's commercial reputation matters to its financial bottom line, so that the defendant's communications that the company was a bad social and environmental actor had a real, measurable impact on the company's financial health. So long as corporations are allowed to sue for defamation those who attempt to discover and publicize bad corporate environmental and labor practices, ${ }^{259}$ the law itself recognizes a distinction that seems to elide Justice Breyer. Moreover, so long as such commercial defamation actions are permitted, there is no baseline of free market competition in speech about corporate behavior.

In terms of my earlier, economic analysis, the functioning of the SR market depends crucially upon the ability of firms and other actors with good SR records to effectively distinguish themselves from firms with poor SR records. My argument here is that in the absence of potential civil liability for false SR claims, it may be impossible for the "good" SR firms to effectively distinguish themselves from the "bad" SR firms. More precisely, the speech at issue in Nike v. Kasky cost so little from Nike's point of view as to constitute cheap talk. By attaching liability to false cheap talk, California's false advertising law effectively makes such talk costly. A perfect liability rule - one that attached liability to such statements if and only if they are actually false - would cause the cost of such messages to be perfectly correlated with the firm's actual performance: Companies with good labor records would

\footnotetext{
${ }^{257}$ Where they are known as SLAPP lawsuits [add cites and brief discussion]

258 The case eventually led to a judgment by the European Court of Human Rights requiring that the British government provide legal aid to cover the legal defense costs of such defamation defendants. See John Vidal, 20-Year Fight Ends with Libel Law in the Dock, The Guardian Weekly, 5, Feb. 16, 2005.

${ }^{259}$ For an example of a recent lawsuit of this sort, see Peter DeSimone, Cintas Sues Walden For Defamation, IRRC Corp. Social Issues Reporter 1 (Feb. 2004)(describing defamation action by U.S.'s largest uniform rental and industrial launderer against corporate owner of Walden Asset Management for "substantial injury" caused
} 
face no liability; those with poor records who claim to have good ones would face liability. No company would send a false message, since doing so would entail cost (liability), while failing to communicate the desired message (assuming, of course, that the finding of falsity becomes common knowledge among SR consumers and investors). More generally, under an imperfect liability rule, a company's expected net benefit from making claims of corporate SR will fall (benefits fall and costs increase), the higher is its perceived probability that the claims will be found to be false. Hence in equilibrium under such an imperfect liability rule, fewer companies will communicate regarding corporate SR, but those communications that are sent will be more likely to be true, and hence will have greater market impact. SR consumers and investors will get more information, thus allowing companies who truthfully make corporate SR claims to benefit from stock and product price premia.

This argument may in fact overstate the risk of imperfect liability. After all, the statute invoked by the private plaintiff in Nike v. Kasky was not one that authorized damages but rather injunctive relief. ${ }^{260}$ Both Justice Breyer and the Solicitor General (in its amicus brief) were especially disturbed by the fact that the California statute allowed such private actions without requiring the plaintiff to allege individual injury, thus seemingly bypassing the constitutional requirements for standing. ${ }^{261}$ But however troubling, this aspect of the California statutory scheme, ${ }^{262}$ the fact that the remedy sought was an injunction rather than damages changes significantly the "chilling" argument against liability. The cost to a

to Cintas's "business, goodwill and reputation" by Walden employee's accusations at annual shareholder meeting that Cintas contracted with a Haitian factory that was a 'poster child for sweatshops.')

${ }^{260}$ Cal. Bus. \& Prof. Code $\$ 17203$ (2005).

${ }^{261}$ See Trevor W. Morrison, Private Attorneys General and the First Amendment, 103 Mich. L. Rev. 589, 591 (2005).

262 Private attorney general enforcement is in fact a relatively common feature of state unfair competition and consumer protection laws. See Morrison, supra note _ at 605-606. The rather odd "no injury" aspect of California's statute was eliminated by Proposition 64, approved by referendum on November 2, 2004. Proposition 64 amended \$\$17203-17204 of the California Business and Professions Code to require that 
company of an injunctive remedy that orders it to stop lying about its labor or environmental practices is primarily a market, reputational cost, one that is more or less identical to the cost it would bear if a reputable journalist had publicly revealed that it had been lying about those practices. It is true that if the company was shown to be in violation of such an injunction, then it might face monetary sanctions. Such a highly attenuated path to relatively potential monetary sanctions, however, simply does not have the same potential to chill corporate speech as does the prospect of paying compensatory or punitive damages.

Recent events go further, suggesting that far from chilling informative corporate speech, Nike v. Kasky may have actually led to an increase in the informativeness of CSR communications. It is true, as observed by Justice Breyer's concurrence, that in response to Kasky's suit, Nike stopped producing and distributing its annual CSR report. This might seem to prove the speech-chilling effect of such lawsuits. But after three years of silence, Nike has recently reinitiated its CSR communications. Not only has Nike published a CSR report, but it has put a complete list of its suppliers on its website. ${ }^{263}$ Heralded as opening up a new era on CSR, ${ }^{264}$ Nike's public position is that it hopes that other companies will follow its lead so that all may work together to find new ways to both improve working conditions and lower costs. ${ }^{265}$ The desire to help competitors lower costs is implausible. Reading between the lines, Nike has adopted a new, and quite clever SR signaling strategy. It is clearly challenging its competitors to similarly make their supplier lists publicly available. By lowering the costs to journalists and activists of investigating its own labor practices, Nike is attempting to distinguish itself as an SR "good" company relative to firms that refuse

private attorney general plaintiffs must establish standing by alleging that they have suffered harm due to the defendant's false advertising.

${ }^{263}$ Sarah Murray, Nike Makes the Step to Transparency, Financial Times, p. 8, April 13, 2005.

${ }^{264}$ Michael Skapinker, Nike Ushers in a New Age of Corporate Responsibility, Financial Times, 8, April 20, 2005. 
to make such lists publicly available. The simple publication of a list of its own suppliers' facilities, moreover, makes no affirmative claim that could ground potential liability. Thus Nike has found a way to avoid potential liability for false claims about its labor practices by lowering the cost to third parties of investigating and revealing those practices. In this, Nike v. Kasky may herald the way toward a new and more cooperative relationship between companies and their critics, one that uses third party market certification as a substitute for legal liability.

2. The Limits to Private, Market Certification of Truthful CSR Communication: On the Necessity of Liability for False Communications

Nike's recently adopted approach to CSR communication -- to avoid making claims about its labor practices, while making it cheaper for third parties to investigate and publicize those practices - is a short but as I shall argue significant step away from the strategy of private, third party certification that a large number of companies have already adopted. Under this strategy, corporations seek to establish the truthfulness of their CSR claims having those claims verified by independent third party organizations. Such certification comes in two basic forms. Sometimes, as in the case of a number of the biggest international banks, firms agree to follow "best practices" that have been devised by, or with, ngo's or other institutions, and to allow those ngo's to monitor their compliance with those practices. ${ }^{266}$ Such partnerships generate a message to SR consumers and investors that the

\footnotetext{
${ }^{265}$ Skapinker, Nike, supra note

${ }^{266}$ Sixteen of the world's largest banks have adopted the Equator Principles, which establish rules for SR lending practices, and periodically meet with representatives of roughly a dozen international ngo's in reviewing their progress in implementing these Principles. See www.equator-principles.com/index.html. In a related action, the Rainforest Action Network mounted a vigorous, multifaceted campaign that persuaded Citigroup to agree to follow an even more extensive set of SR lending guidelines, an action that Rainforest Action Network then used as a springboard to get a number of other large banks to agree. See [Rainforest Action Network website]. For other prominent examples of such partnerships, see Peter DeSimone, Gap Comes Clean on Supplier Factories, IRRC Corp. Social Issues Reporter 1, 5 (May, 2004) (reporting on collaboration between Gap and five SR shareholder advocacy groups in Gap's adoption of new reports on its supplier factory labor
} 
participating companies are doing the right thing, as evidenced by the active participation and endorsement of various ngo's. ${ }^{267}$ The second strategy is to make standardized CSR disclosures whose accuracy is certified by independent accounting or environmental consulting firms. ${ }^{268}$

In both cases - partnerships and certification - firms use third party auditing and endorsement as a way of establishing the credibility of their CSR claims. Such certification is a market response to the problem of establishing credibility, a response that might seem to eliminate the need for legal liability of the sort exemplified by Nike v. Kasky. Rather than making their own, independent claims, and risking liability, firms may seek to enlist ngo’s and accounting firms as partners who independently verify the truthfulness of the firms' claims. Moreover, in designing standardized disclosure protocols, such private certification firms and institutions make it easier for SR investors and consumers to compare across firms, thus increasing the informativeness and social value of truthful corporate speech. ${ }^{269}$

These developments suggest a limited legal role, both in mandating environmental disclosure and in attaching liability for false disclosures. What we are seeing, it may be argued, is a natural market response to the rise of the SR market. An industry of private ngo's, accounting firms and certification organizations has arisen to provide the information about firm CSR that SR consumers and investors demand. The market will not only ensure truthful CSR communication, by providing standardized reporting protocols and verifying

practices, and on plans to extend the partnership approach to Disney, McDonald's and Nike), [add other prominent examples of such partnerships include MacDonald's repackaging, Home Depot's purchasing, etc.]

${ }^{267}$ Immediately after reaching agreement with Citigroup, for example, the Rainforest Action Network's website proclaimed "World's Largest Bank Makes Huge Step Toward Sustainability." See Mathiasen and Voorhes, Citigroup, RAN Reach Accord, supra note _ at 17.

268 There are a number of examples of this strategy. See, for example, the annual CSR reports of a number of the major oil companies [finish note].

${ }^{269}$ From what began as a mélange of over thirty frameworks for corporate environmental reporting, the Global Reporting Initiative (GRI) has emerged as a standard reporting framework, one that is now utilized by over half of the Fortune 250 companies. See Case, Corporate Environmental Reporting, supra note _ at 399-401. 
such standardized reports, but also guide and audit the actual firm SR practices that are being reported about. Market demand will be met by market supply.

This conclusion is simplistic. The problem is precisely the general one discussed earlier: markets trust private certification of the truthfulness of corporate disclosures only if market participants trust the certifiers to be careful and also not to collude with the firms they are certifying. In the financial and accounting literature, there is a well-developed literature that attempts to explain precisely when and why markets trust accounting firm audit reports. On the theory side, that literature argues that audits are trustworthy and valuable only if either a) auditors have valuable reputations and will lose future business if they are discovered to have issued a negligently or intentionally false report, ${ }^{270}$ or b) face legal liability for negligent or false reports. ${ }^{271}$ Empirical work has largely confirmed the fundamental implication of both of these theories, which is that financial audits by larger accounting firms, who have both more reputational and financial capital at stake, will be more accurate signals of firms' actual financial condition and have a bigger impact on stock market prices of audited firms. ${ }^{272}$

This work has direct application to the developing market for private certification of CSR disclosures. As partnerships involving ngo's and corporations and various forms of private CSR certification have proliferated, so too has the level of expressed concern over the possibility of collusive arrangements between firms and their CSR partners and

\footnotetext{
${ }^{270}$ Larry DeAngelo, Auditor Size and Auditor Quality, 3 J. Acct. \& Econ. 183 (1981).

${ }^{271}$ Richard Dye, Auditing Standards, Legal Liability and Auditor Wealth, 101 J. Pol. Econ. 887 (1993); for an interesting recent extension, see Sasson Bar-Yosef and Bharat Sarath, Auditor Size, Market Segmentation and Litgation Patterns: A Theoretical Analysis, 10 Rev. Acct. Stud. 59 (2005).

${ }^{272}$ For an interesting recent contribution to this literature containing a review of many of the important earlier empirical work, see Clive S. Lennox, Audit Quality and Auditor Size: An Evaluation of the Reputation and Deep Pockets Hypotheses, 26 J. Bus. Fin. \& Acct. 779 (1999). For a study finding that audit clients suffer a decline in stock market valuation when their auditing firms' reputations decline due to government agency criticism, see Michael Firth, Auditor Reputation: the Impact of Critical Reports Issued by Government Inspectors, 21 Rand J. Econ. 374 (1990).
} 
auditors. ${ }^{273}$ The literature on financial audit credibility implies that SR markets will react most to CSR certifications done by larger, well established ngo's and accounting firms, firms with a lot to lose if they are found to have either negligently or collusively falsely certified a firm's CSR disclosures as accurate. On this reasoning, one would indeed expect the most credible third party certifiers to be auditing and environmental ngo's with the strongest overall financial base and who are most independent financially of the firms who they are certifying. That is, for SR investors and consumers, the key to deciding whether one can trust a third party certification may be the financial relationship between the third party and the certified firm. As in the financial accounting field, where regulations have now forced a separation between the consulting and auditing operations of large accounting firms, so too might it be found desirable to prevent accounting firms providing consulting services to firms from also providing SR certifications. In the alternative, it might be found necessary to mandate that both accounting firms and ngo's who provide forms of CSR certification publicly disclose their financial relationship to the SR-audited firms. Such disclosure would enable SR investors and consumers to discover the extent to which supposedly objective, third party CSR certifiers are financially dependent upon the firms they are certifying.

But now we are back to the beginning. For if financial disclosure by third party certifiers is necessary for SR consumers and investors to decide which certifications to trust, then those financial disclosures themselves would somehow need to be trustworthy. We risk an infinite regress of certification of disclosures by certifiers who must disclose whose own

\footnotetext{
${ }^{273}$ For a sample of many instances of such criticism, see Beach Ratings are Criticized in California, New York Times, July 26, 2004 (California officials and environmentalists alleging that California beaches were not highly rated by the Washington, D.C. Clean Beaches Council because they refused to pay fees of $\$ 1500$ to $\$ 2500$ per beach for ratings); Sharon Beder, Environmentalists Help Manage Corporate Reputation: Changing Perceptions not Behavior, 1 Ecolpolitics 60 (2002)(describing pattern of large contributions to various environmental ngo's by firms who are heavy polluters); The Rainforest Foundation, Trading in Credibility: The Myth and Reality of the Forest Stewardship Council (date, URL)(finding that FSC certifications of sustainable forestry practices are often strongly influenced by pressure from corporate forest owners).
} 
disclosure must be certified by certifiers who must themselves disclose, and so on.

Ultimately, as with financial audits, if SR consumers and investors are to commit substantial sums in reliance upon private SR audits, then the auditors themselves must face shared legal liability with the firms whom they audit. The market option of private certification rests, in the end, upon the very system of legal liability that seemed at first to obviate. 